Historic, Archive Document

Do not assume content reflects current scientific knowledge, policies, or practices. 

然

o

THE EFFECTS OF FIRE AND

OTHER DISTURBANCES ON

SMALL MAM MALS AND THEIR

PREDATORS: AN

ANNOTATED BIBLIOGRAPHY

[a.....
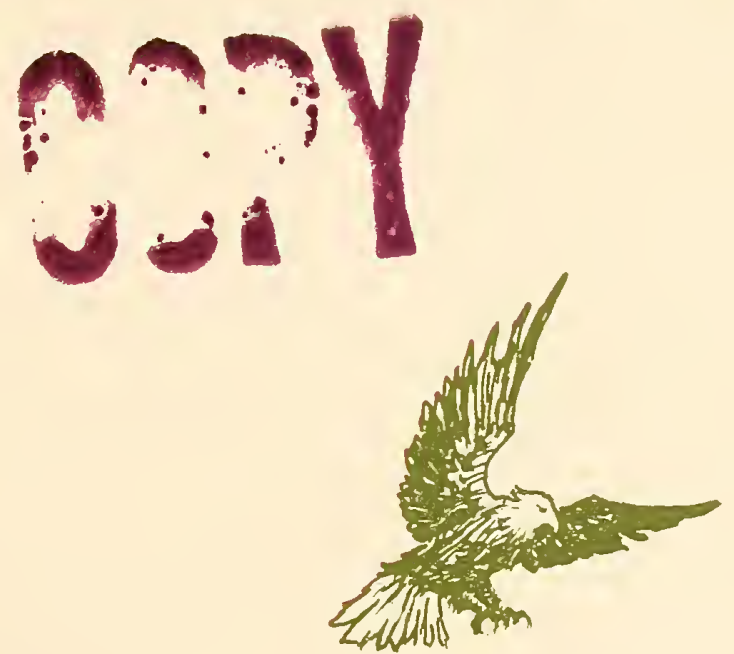

USDA Forest Service General Technical Report INT-106 Intermountain Forest and Range Experiment Station

U.S. Department of Agriculture, Forest Service

f)

(n)

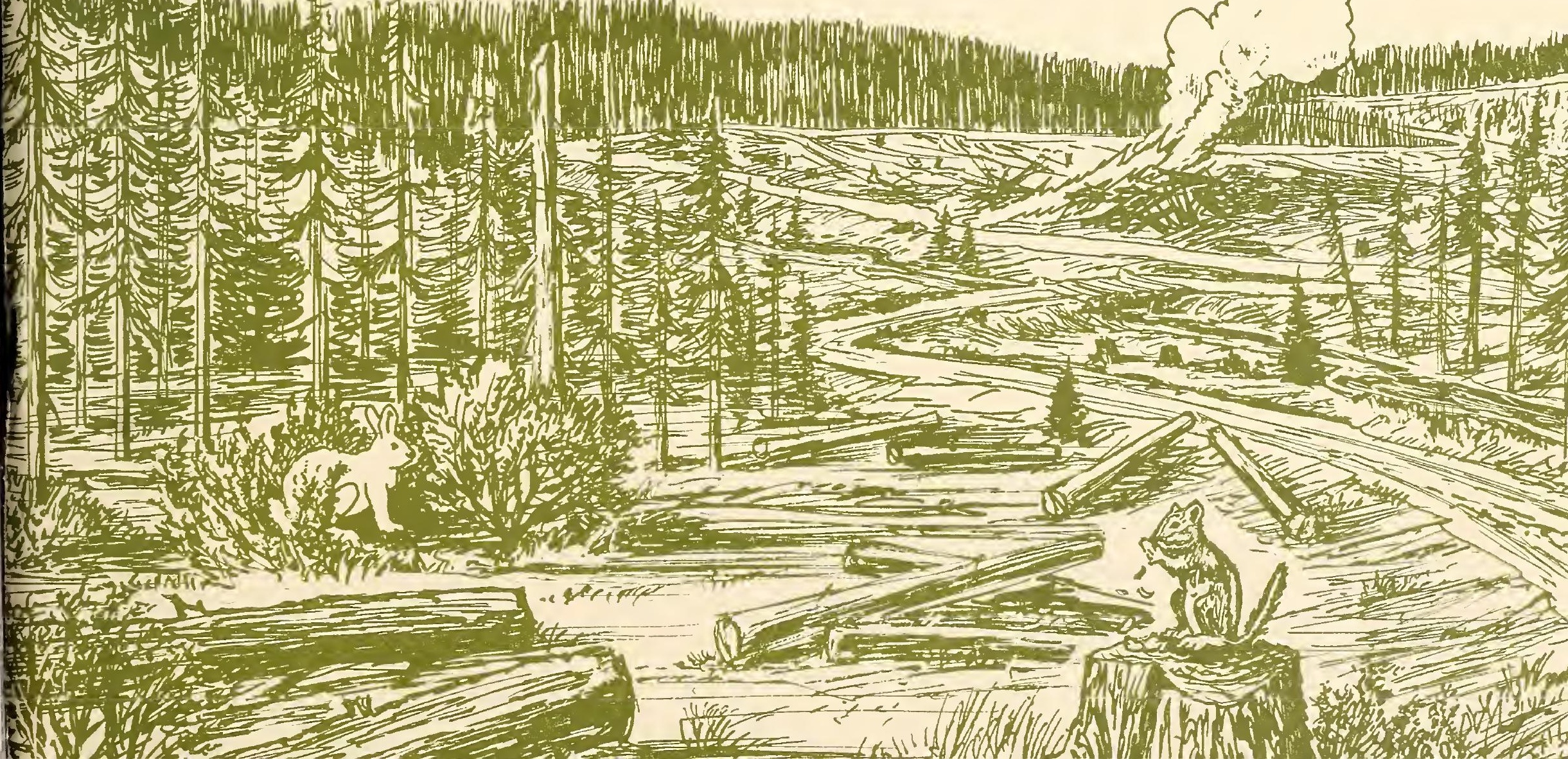


USDA, National Agricultural Library

NAL Bidg

10301 Bartimore Blvd

Beltsville, MD 20705.2351 


\title{
THE EFFECTS OF FIRE AND OTHER DISTURBANCES ON SMALL MAMMALS AND THEIR PREDATORS: AN ANNOTATED BIBLIOGRAPHY
}

\author{
Compiler \\ Catherine H. Ream
}




\section{THE COMPILER}

DR. CATHERINE H. REAM has her B.S., M.S. and Ph.D. degrees in zoology with a plant ecology minor from the University of Wisconsin in Madison. She has done research and published on turtles, lizards, loons, small mammals, and the effects of recreationists on wildlife in backcountry areas, and has worked on the vegetation of the Boundary Waters Canoe Area and the effects of fire and logging on elk and other wildlife. The present bibliography was accomplished through an Interpersonal Loan Agreement from the Forestry School of the University of Montana to the Fire Effects.and. Use Research and Development Program at the Northern Forest Fire Laboratory in Missoula.

\section{RESEARCH SUMMARY}

This report contains an annotated bibliography of the effects of fire, logging, grazing, and spraying on small mammals and their predators. Each citation lists keywords. A brief summary of the general effects of fire on some of the more common small mammals in western coniferous forests is included. 


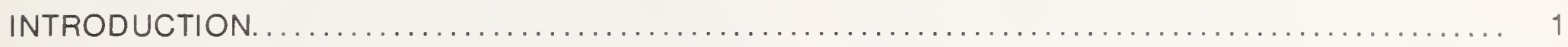

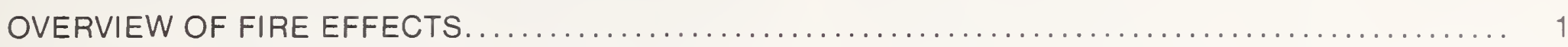

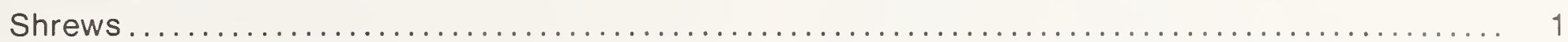

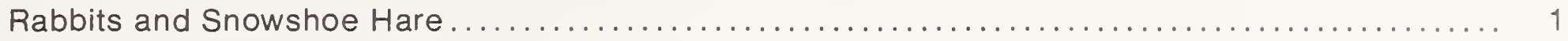

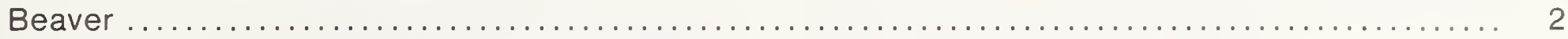

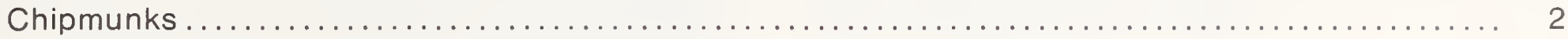

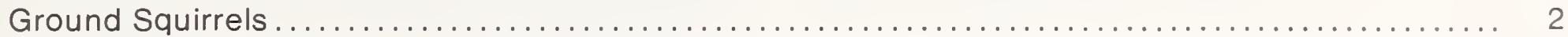

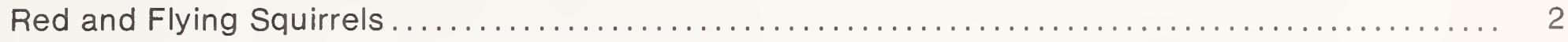

Pocket Gophers................................................................. 2

Deer Mice.......................................................................... 2

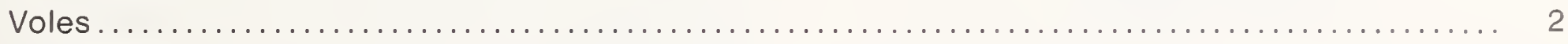

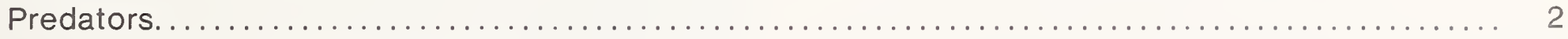

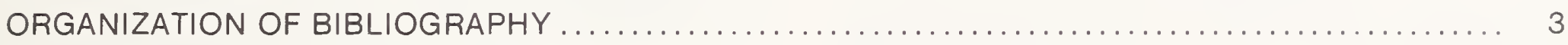

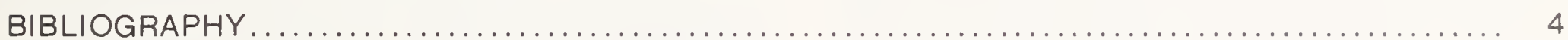

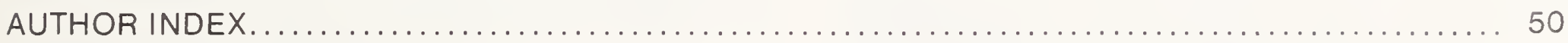

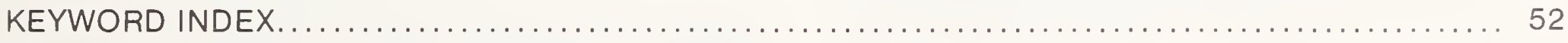

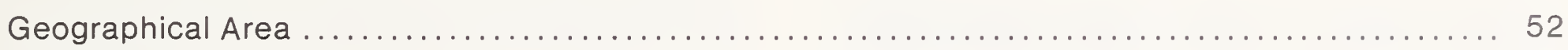

Treatments................................................................... 52

Effects of Treatments .......................................................... 52

Fire Effects on Soil and Moisture ............................................... 52

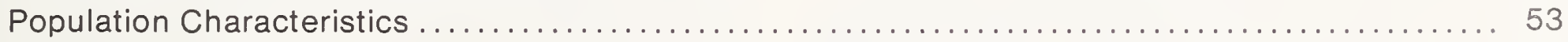

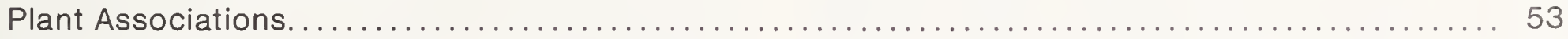

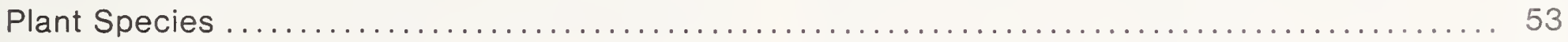

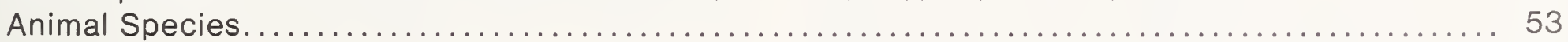

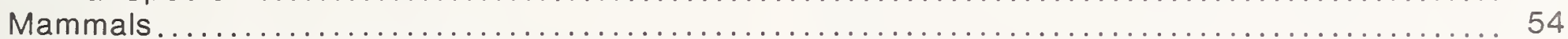

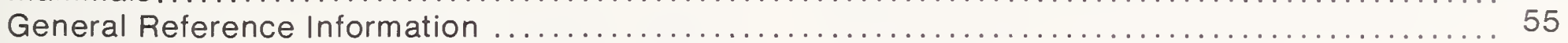





\section{INTRODUCTION}

Recently, there has been increased interest in the effects of disturbances on nongame species of wildlife such as small mammals and their predators. Because time and good library facilities are required to find these references, an annotated bibliography has been compiled to facilitate access to this information for land managers. In addition, a brief summary of the information on the habitat requirements and the effects of fire and other disturbances on some of the morestudied small mammals has been included.

The major effect of disturbances such as fire, logging, grazing, and herbicides on small mammals is the modification of vegetation. For this reason, references describing specific habitat requirements of the common small mammal species are included. Predators tend to be more closely tied to their food source than to other aspects of their habitat (such as vegetation type), so the main effects of disturbance may be through the effects on prey species. Therefore, publications dealing with predator-prey relationships, where small mammals are the prey species, have been included.

There are several small mammals, such as pikas and marmot, for which I found no references related to fire, probably because these animals are associated with fire-resistant, rocky habitats.

Bats are common small mammals for which I found no references on the effects of fire or other disturbances. Certainly, foliage-roosting species are influenced by fire or logging, but this, apparently, has not been researched.

Emphasis is on western coniferous forests, but publications specifically concerned with the effects of fire on small mammals have been included, regardless of geographical area. This bibliography should be useful for references published through 1979. Additional references will be graciously received.

This bibliography is the result of a literature search and the formation of a FAMULUS data file for the Fire Effects R\&D Program, Northern Forest Fire Laboratory. The data file will be utilized in preparation of guidelines and state-of-the-art publications dealing with the effects of fire on resource production.

\section{OVERVIEW OF FIRE EFFECTS}

The responses of small mammal populations to fire and other disturbances are directly related to the modification of vegetation and food sources. Disturbance that removes dominant vegetation results in increased temperature ranges and air movements at the ground surface. Moisture regimes are altered by changes in the amount of precipitation reaching the ground. Dew, evaporation, and transpiration rates are also altered. A few months after disturbance, there is a surge in the growth of herbaceous plants in response to these environmental changes.

Short-term impacts of fire and other disturbance on animals include injury or death, loss of food and cover, and increased exposure to predation. The long-term response of many small mammal species is increased numbers, largely due to the surge in growth of herbaceous and seed-producing plants.

Much of the research on the effects of fire on small mammals was initiated because of the high small mammal populations following timber harvests and the resulting impacts on regeneration. Publications dealing with the effects on small mammals, of wildfire, or prescribed fire for big game habitat, are relatively scarce.

Although contradictions exist, general responses to the effects of fire can be predicted for most species. The following summaries are a synopsis of information from publications representing substantial research on the common species of the Rocky Mountain area for which information is available.

\section{Shrews (Sorex spp.)}

Shrews generally require a mat of ground vegetation for cover. Shrews are insectivores, so they depend less on vegetation for food than do herbivorous species (Rickard 1960). Shrews are temporarily eliminated from areas where fire has removed the duff and ground vegetation, and will not return until a ground cover develops (Black and Hooven 1974). They are often associated with downed logs (Dimock 1974).

\section{Rabbits and Snowshoe Hare (Sylvilagus spp. and Lepus americanus)}

Population highs of rabbits and showshoe hare are associated with shrubs and small, pole-sized confiers (Grange 1965). Hot fires that remove all cover make areas unsuitable as habitat until these successional stages are reached (Keith and Surrendi 1971). Slash piles can provide escape cover and improve the habitat of logged areas for cottontails (Costa and others 1976).

\section{Beaver \\ (Castor canadensis)}

High beaver populations have historically followed disturbances such as fire (Rowe and Scotter 1973) or logging (Patrick and Webb 1953) that initiate a successional sequence in which aspen is an intermediate stage. Beaver population peaks are often correlated with the establishment of aspen (Lawrence 1954; Patrick and Webb 1953). After a single generation, aspen is usually replaced by more tolerant climax species, and beaver populations decline (Lawrence 1954).

\section{Chipmunks (Eutamias spp.)}

Chipmunks prefer partially open areas, but need the shelter provided by fallen trees, limbs, or shrubs. Fire and other disturbances may improve chipmunk habitat by creating openings, especially if these openings 
contain logging slash or rock outcrop cover (Davis 1976; Tevis 1956c). Chipmunks increase with the establishment of seed- and fruit-producing plants (Gashwiler 1970).

\section{Ground Squirrels (Spermophilus spp.)}

Ground squirrels prefer open areas. They feed on plant species that grow in open habitat (Tevis 1953). Burrow systems provide protection from predators, so cover is not as important as it is for chipmunks, and large open areas can be invaded (Tevis 1956b; Gashwiler $1970 \mathrm{~b})$. Fire and other disturbances that remove the forest canopy improve the habitat for these animals (Davis 1976).

\section{Red and Flying Squirrels (Tamiasciurus hudsonicus and Glaucomys spp.)}

Trees are essential for dens of flying squirrels and for dens and nests of red squirrels. These squirrels are displaced when fire or logging eliminates living trees from wide areas (Gashwiler 1970b) (Lyon and others 1978). Cavities in fire-killed trees may be used for dens (Burns, no date) if such snags are surrounded by living trees. Conifer seed is the primary food of red squirrels. Flying squirrels in some areas subsist largely on fungi (McKeever 1960), and may forage in firecreated openings.

\section{Pocket Gophers (Thomomys spp.)}

Pocket gophers are favored by disturbance which removes the forest canopy, scarifies the soil, and results in the development of an herbaceous vegetation food source (Barnes 1974; Volland 1974). In unforested areas, grazing improves gopher habitat (Beuchner 1942). Protective burrow systems allow these animals to use large open areas, lacking protective cover.

\section{Deer Mice (Peromyscus maniculatus)}

Deer mice are a pioneer species. They occur in most vegetation types during most stages of plant succession, but usually not in large numbers. Disturbances that result in early seral stages favor this species (Williams 1955). Deer mice are usually the most abundant small mammal in severely disturbed areas (Halvorson, in press; Dimock 1974). Their success on these sites is apparently due to their food habits (insects, wind- dispersed conifer seeds, and seeds that remain in the soil after burning), their nocturnal habits, erratic movements (that provide protection from predators), and lack of competition from other species.

\section{Voles (Clethrionomys spp. and Microtus spp.)}

Red-backed voles, Clethrionomys spp., and voles of the genus Microtus are associated with the organic layer of the ground surface. Important elements of their environment are a mat of ground cover, platable herbaceous plants, and moisture. A hot fire that destroys the surface organic layer will eliminate voles from an area (Dimock 1974). Logging improves the growth of forbs by decreasing competition for light and soil moisture. After logging, increased numbers of Microtus can be expected, but Clethrionomys populations are usually decimated by the removal of the forest canopy (Halvorson, in press; Halvorson, personal communication) and resulting lack of free surface water (Odum 1944). Occasionally, red-backed vole populations remain high after logging until the slash is burned. After burning, populations decline (Gashwiler 1959).

\section{PREDATORS}

Numerical data on the effects of fire on diversity and numbers of predators are scarce. There are, however, some general observations. Marten need climax forest communities and will be eliminated by catastrophic fire. They do benefit, however, from the vegetative mosaic resulting from regeneration following periodic small fires (Koehler and Hornocker 1977), and may not be adversely affected by selective timber harvesting (Soutiere 1979). Hawks may temporarily congregate to hunt in the vicinity of a recent burn (Baker 1940). Coyote and lion populations increase several years after fire in response to increased numbers of prey (Edwards 1954). A study of a raccoon family showed no change in the use of an area immediately after it burned (Sunquist 1967).

Although these observations are undoubtedly accurate, I am not aware of any studies that actually document numerical increases in predators following fire. The difficulties of accruing this kind of information are several:

1. Even in dense populations, predators are rare, compared to their prey.

2. Most predatory species are, by nature, very elusive.

3. Studies of predators, to be valid, need to be longterm (10 years or more).

4. The home range of many predators is so large that residence cannot usually be defined within a single burned area. 


\section{ORGANIZATION OF THE BIBLIOGRAPHY}

The publications are listed alphabetically by author. Each publication is numbered. The annotations relate the information pertaining to the subject of this bibliography and are not meant to be abstracts. Keywords are given for each publication. A numeric rating of 1,2, or 3 is included with the keywords. Papers rated 1 pertain more closely to the subject of this bibliography than papers rated 3 . The keywords are arranged after the author index by geographic area, land treatment, effects of treatments, small mammal population characteristics, plant associations, plant species, animal species, and general reference information. Common and scientific names are used in the species indexes. Mammalian nomenclature has been standardized and follows Jones, Carter, and Genoways (1975).

The indexing system can be used in several ways. It can be used to search for publications about deer mice, or to search several words simultaneously, such as deer mouse and Douglas-fir, and to check for matching reference numbers; or the author index could be used to look for reference numbers of publications of individuals known to have studied deer mice. 


\section{BIBLIOGRAPHY}

1 AUTH ABRAMSKY Z., DYER M. I., HARRISON P. D.

DATE

TITI

1979 .

COMPETITION AMONG SMALL MAMMALS IN EXPERIMENTALLY PERTURBED

AREAS OE THE SHORTGRASS PRAIRIE.

PUBL ECOLOGY 6O(3):530-536.

ANNO TREATMENT OF SHORTGRASS PRAIRIE WITH NITROGEN AND WATER RESULTED IN INCREASED POPULATIONS OF THE RELATIVELY RARE HARVEST MOUSE AND PRAIRIE VOLE WHILE COMMON SPECIES FOR THIS AREA, DEER MICE, 13-LINED GROUND SQUIRRELS AND GRASSHOPPER MICE AVOIDED THE TREATED AREA. WHEN THE INVADING SPECIES WERE REMOVED, DEER MICE INCREASED, APPARENTLY BECAUSE OF THE LACK OF COMPETITION. GRASSHOPPER MICE DID NOT INCREASE SUGGESTING A HABITAT PREEERENCE DIFEERENT THAN THE TREATED AREA. THE 13-LINED GROUND SOUIRRELS HIBERNATED DURING THE EXPERIMENTAL PERIOD.

KEYS SMALL MAMMALS, GRASSLAND, 1, DEER MOUSE, THIRTEEN-LINED GROUND SOUIRREL, WESTERN HARVEST MOUSE, PRAIRIE VOLE, NORTHERN GRASSHOPPER MOUSE, COLORADO, VEGETATION STRUCTURE

2 AUTH ADAMS L.

DATE 1950.

TITL CONSUMPTION OE PONDEROSA PINE SEED BY SMALL MAMMALS.

PUBL USDA FOR. SERV., RES. NOTE NO. 80. 4P. NORTH. ROCKY MT. FOR. RANGE EXP. STN., MISSOULA, MONT.

ANNO AMOUNT OE PONDEROSA PINE SEED DESTROYED BY SMALL MAMMALS, ESPECIALIY WHITE-FOOTED MICE AND CHIPMUNKS, IS SUBSTANTIAL.

KEYS SMALL MAMMALS, FOOD HABITS, PONDEROSA PINE, IDAHO, MONTANA, WHITE-FOOTED MOUSE, CHIPMUNKS, 2

3 AUTH ADAMS L.

DATE 1959.

TITL AN ANALYSis OF A POPULATION OE SNOWSHOE HARES IN NORTHWESTERN MONTANA.

PUBL ECOL. MONOGR. 29(2):141-170.

ANNO GENERAL LIFE HISTORY OE SNOWSHOE HARES. HARES PREFER TO STAY IN AREAS WHERE THE VEGETATION OEFERS PROTECTIVE COVER. WHEN THIS COVER BECOMES TOO DENSE, EOOD PLANTS CAN NO LONGER GROW THERE AND THE HARE HAVE TO MOVE INTO MORE OPEN AREAS TO EEED, INCREASING THEIR VULNERABILITY TO PREDATION. GREAT HORNED OWLS ARE THE MOST IMPORTANT PREDATOR.

KEYS SMALL MAMMALS, SNOWSHOE HARE, MONTANA, FOOD HABITS, POPULATION DENSITY, RAPTORS, GREAT HORNED OWL, PREDATORS, MINK, VEGETATION STRUCTURE, 2

4 AUth ADAMS L., HANAVAN M.G., HOSLEY N. W., JOHNSON D. W. DATE 1949.

TITL THE EFEECTS ON EISH, BIRDS AND MAMMALS OF DDT USED IN THE CONTROL OE FOREST INSECTS IN IDAHO AND WYOMING.

PUBL J. WILDL. MANAGE. $13(3): 245-254$.

ANNO $8.5 \mathrm{KG} / \mathrm{HA}$ DDT APPLIED TO FOREST LAND TO CONTROL TUSSOCK MOTH HAD NO APPARENT AEEECT ON SMALL MAMMALS EXCEPT FOR TREMORS IN SOME CHIPMUNKS AND A SHREW WHICH SHOWED TYPICAL SYMPTOMS OF DDT POISONING.

KEYS EISH, BIRDS, SMALL MAMMALS, INSECTICIDE, WYOMING, IDAHO, CHIPMUNKS, SHREWS, 3 
AUTH ADELMAN E.

DATE 1979.

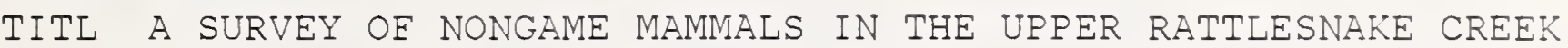
DRAINAGE OE WESTERN MONTANA.

PUBL M.S. THESIS, UNIV. MONT., MISSOULA. 129 .

ANNO DISCUSSES THE IMPACTS OE LOGGING, EIRE, AND RECREATION ON SMALL MAMMALS AND PREDATORS.

KEYS SMALL MAMMALS, HABITAT, MONTANA, PREDATORS, FIRE, LOGGING, PLANT SUCCESSION, 2

6 AUTH AGEE J. K.

DATE 1974.

TITL ENVIRONMENTAL IMPACTS EROM EIRE MANAGEMENT ALTERNATIVES.

PUBL NATL. PARK SERVICE, 92P. WESTERN REGIONAL OFFICE, SAN ERANCISCO, CALIE.

ANNO DESCRIBES GENERAL DIRECT AND INDIRECT IMPACTS OE UNCONTROLLED EIRE ON WILDLIEE.

KEYS SMALL MAMMALS, LARGE MAMMALS, MORTALITY, WILDFIRE, SOIL CHARACTERISTICS, BIRDS, 2

7 AUTH AHLGREN C. E.

DATE 1963.

TITL SOME BASIC ECOLOGICAL FACTORS IN PRESCRIBED BURNING IN NORTHEASTERN MINNESOTA.

PUBL TALL TIMBERS EIRE ECOL. CONE. 2:143-149.

ANNO THE EIRST YEAR AETER EIRE SEED EATING SMALL MAMMALS AND BIRDS INCREASED. THE SECOND YEAR THE NUMBERS OF THESE SPECIES WERE NEAR NORMAL. IN LABORATORY STUDIES PEROMYSCUS CONSUMED 185 JACK PINE SEEDS/DAY.

KEYS DEER MOUSE, PINE SISKIN, POPULATION DENSITY, FOOD HABITS, JACK PINE, MINNESOTA, SMALL MAMMALS, PRESCRIBED EIRE, 1, BIRDS

8 AUTH AHLGREN C. E.

DATE 1966.

TITL SMALL MAMMALS AND REEORESTATION FOLLOWING PRESCRIBED BURNING. PUBL J. FOREST. 64(9):614-618.

ANNO RESPONSES OE DEER MICE, RED-BACKED VOLES AND LEAST CHIPMUNKS POPULATIONS IN A CUT AREA, TWO CUT AND BURNED AREAS, AND A CONTROL AREA, WERE DETERMINED BY SNAP TRAPPING EOR 3 CONSECUTIVE YEARS.

KEYS SMALL MAMMALS, RED-BACKED VOLES, DEER MOUSE, LEAST CHIPMUNK, EOOD HABITS, POPULATION DENSITY, POST-EIRE SUCCESSION, HABITAT, JACK PINE, LOGGING, MINNESOTA, PRESCRIBED EIRE, 1

9 AUTH AMBROSE H. W.

DATE 1972 .

TITL EFEECT OE HABITAT EAMILIARITY AND TOE-CLIPPING ON RATE OF OWL PREDATION IN MICROTUS PENNSYLVANICUS.

PUBL J. MAMMAL. 53(4):909-912.

ANNO VOLES EAMILIAR WITH THEIR ENVIORNMENT WERE CAPTURED LESS READILY THAN ANIMALS NEWLY RELEASED. TOE-CLIPPING HAD NO SIGNIEICANT EFEECT ON RATE OE PREDATION.

KEYS SMALL MAMMALS, PREDATION, RAPTORS, BARN OWL, VOLES, 2

10 AUTH AMBROSE R. E.

DATE 1975.

TITL THE EEEECT OE CLEARCUTTING ON BIRD AND SMALL MAMMAL POPULATIONS.

PUBL PH.D. DISSERTATION. UNIV. TENN., KNOXVILLE. 287 P. 
ANNO THE WHITE-EOOTED MOUSE, EASTERN CHIPMUNK AND SHORT-TAILED SHREW WERE ALL MORE ABUNDANT ON CLEARCUTS THAN IN ADJACENT FOREST.

KEYS BIRDS, SMALL MAMMALS, CLEARCUT, TENNESSEE, RAPTORS, WHITE-FOOTED MOUSE, EASTERN CHIPMUNK, SHORT-TAILED SHREW, PREDATORS, LONG-TAILED WEASEL, POPULATION DENSITY, RESIDUE TREATMENTS, SELECTIVE CUT, I

11 AUTH ANDELT W. F., GIPSON P. S.

DATE 1979.

TITL DOMESTIC TURKEY LOSSES TO RADIO-TAGGED COYOTES.

PUBL J. WILDL. MANAGE. 43(3)673-679.

ANNO DESCRIBES PREDATION ON DOMESTIC TURKEYS BY RADIO-COLLARED COYOTES.

KEYS PREDATORS, COYOTE, PREDATION, DOMESTIC TURKEY, NEBRASKA, 2

12 AUTH ANDELT W. E., GIPSON P. S.

DATE 1979.

TITL HOME RANGE, ACTIVITY, AND DAILY MOVEMENTS OF COYOTES.

PUBL J. WILDL. MANAGE. 43(4):944-951.

ANNO DESCRIPTION OF THE ACTIVITIES AND MOVEMENTS OF TOE-CLIPPED AND RADIO-EOUIPPED COYOTES.

KEYS PREDATORS, COYOTE, NEBRASKA, MOVEMENTS, HOME RANGE, HABITAT, 3

13 AUTH ANDERSON R. J., BARNES V. G., BRUCE A. M.

DATE 1976.

TITL A BIBLIOGRAPHY OF POCKET GOPHERS FAMILY GEOMYIDAE.

PUBL WEYERHAUSER FORESTRY PAPER NO. 16. $50 P$.

ANNO COMPREHENSIVE POCKET GOPHER BIBLIOGRAPHY.

KEYS BIBLIOGRAPHY, SMALL MAMMALS, POCKET GOPHERS, 2

14 AUTH AUMANN G. D.

DATE 1965.

TITL MICROTENE ABUNDANCE AND SOIL SODIUM LEVELS.

PUBL J. MAMMAL 46:594-604.

ANNO CORRELATES PEAK VOLE DENSITIES WITH THE ABUNDANCE OE SODIUM IN THE SOIL.

KEYS SMALL MAMMALS, VOLES, POPULATION DENSITY, SODIUM, 2

15 AUTH BAKER R. H.

DATE 1940.

TITL EEEECT OF BURNING AND GRAZING ON RODENT POPULATIONS.

PUBL J. MAMMAL. 21:223.

ANNO CONCLUDES THAT GRAZING AND BURNING, ESPECIALLY THE LATTER

REDUCES THE SMALL RODENT POPULATION. DESCRIBES THE ATTRACTION OF HAWKS TO WINTER BURNS. SHREWS WERE NOT CAUGHT IN TRAPS BUT CONSTITUTED 41\% OF MAMMALIAN REMAINS IN OWL PELLETS FROM THE SAME AREAS.

KEYS SMALL MAMMALS, HARVEST MOUSE, NORTHERN PIGMY MOUSE, COTTON RAT, RAPTORS, GRASSLAND, GRAZING, POPULATION DENSITY, TEXAS, PREDATION, PRESCRIBED FIRE, 2

16 AUTH BAKER W. W.

DATE 1973.

TITL LONGEVITY OF LIGHTNING-STRUCK TREES AND NOTES ON WILDLIEE USE.

PUBL TALL TIMBERS EIRE ECOL. CONE. 13:497-504.

ANNO SMALL MAMMALS USE BURNED OUT ROOT SYSTEMS OF LIGHTNING KILLED TREES.

KEYS SNAGS, BIRDS, SMALL MAMMALS, REPTILES, 3 
17 AUTH BARMORE W. J. JR., TAYLOR D., HAYDEN P.

DATE 1976.

TITL ECOLOGICAL EFEECTS AND BIOTIC SUCCESSION EOLLOWING THE 1974 WATEREALLS CANYON EIRE IN GRAND TETON NATIONAL PARK.

PUBL RESEARCH PROG. REP. 1974-1975. GRAND TETON NATIONAL PARK. 99P.

ANNO LIVE TRAPPING DATA INDICATE THAT EIRE CAUSED A CHANGE IN THE SPECIES COMPOSITION AND RELATIVE ABUNDANCE OF SMALL MAMMALS.

KEYS SMALL MAMMALS, BIRDS, MORTALITY, SPECIES COMPOSITION, POPULATION DENSITY, GRAND TETON NATIONAL PARK, POST-EIRE SUCCESSION, WILDEIRE, 2

18 AUTH BARNES V. G. JR.

DATE 1974

TITL RESPONSE OF POCKET GOPHER POPULATIONS TO SILVICULTURAL PRACTICES IN CENTRAL OREGON.

PUBL IN WILDLIEE AND EOREST MANAGEMENT IN THE PACIEIC NORTHWEST. P. 267-276. H.C. BLACK ED., 1973 SYMP. ORE. STATE UNIV., CORVALLIS.

ANNO RECOMMENDS ASSESSING GOPHER POPULATIONS BEFORE LOGGING. IN AREAS WHERE GOPHERS MAY PREVENT REFORESTATION, APPROPRIATE SILVICULTURAL PRACTICES SHOULD BE USED.

KEYS OREGON, LOGGING, CLEARCUT, HABITAT, 1

19 AUTH BECK A. M., VOGL R. J.

DATE 1972 .

TITL THE EEEECTS OE SPRING BURNING ON RODENT POPULATIONS IN A BRUSH PRAIRIE SAVANNA.

PUBL J. MAMMAL. 53(2):336-346.

ANNO EIRE WAS USED TO CONVERT A EOREST WITH SUPPRESSED PRAIRIE UNDERSTORY BACK TO BRUSH PRAIRIE SAVANNA. THE SMALL MAMMAL RESPONSE WAS CONSIDERED TO BE A RESULT OE THE CHANGE IN VEGETATION. PEROMYSCUS LEUCOPUS AND CLETHRIONOMYS GAPPERI WERE BEST ADAPTED TO THE UNBURNED EOREST AND P. MANICULATUS AND SPERMOPHILUS TRIDECEMLINEATUS TO EIRE MAINTAINED PRAIRIE.

KEYS SMALL MAMMALS, WHITE-EOOTED MOUSE, DEER MOUSE, THIRTEEN-LINED GROUND SOUIRREL, RED-BACKED VOLES, HABITAT, FOOD HABITS, POPULATION DENSITY, SPECIES DIVERSITY, FIRE DISCLIMAX, BRUSH-GRASS, WISCONSIN, MORTALITY, RAPTORS, PREDATION, VEGETATION STRUCTURE, PRESCRIBED EIRE, I

20 AUTH BENDELL J. E.

DATE 1961

TITL SOME FACTORS AEEECTING THE HABITAT SELECTION OE THE WHITE-EOOTED MOUSE.

PUBL CAN. FIELD-NAT. $75(4): 244-255$.

ANNO DISTRIBUTION OE WHITE-FOOTED MOUSE STUDIED IN RELATION TO COVER, FOOD AND POPULATION STRUCTURE. MICE SELECTED ROCK COVER AND AVOIDED GRASSEORM COVER. IN DENSE POPULATIONS, LESS DESIRABLE HABITATS WERE FILLED. HABITAT SELECTION APPEARED TO BE MORE EOR PROTECTIVE COVER, THAN EOR EOOD.

KEYS SMALL MAMMALS, WHITE-FOOTED MOUSE, EOOD HABITS, VEGETATION STRUCTURE, ONTARIO, 2

21 AUTH BENDELL J. F.

DATE 1974.

TITL EEEECT OE EIRE ON BIRDS AND MAMMALS.

PUBL IN EIRE AND ECOSYSTEMS. P. 73-138. T. T. KOZLOWSKI/C.E. ALGREN, EDS. ACADEMIC PRESS, NEW YORK. 
ANNO THOROUGH REVIEW OF LITERATURE COVERING VIRTUALLY ALL EFFECTS OF EIRE ON WILDLIEE.

KEYS SMALL MAMMALS, BIRDS, FIRE, POPULATION DENSITY, POST-EIRE SUCCESSION, HABITAT, BIBLIOGRAPHY, MICROCLIMATE, VEGETATION STRUCTURE, MOSAIC, PREDATION, RAPTORS, PREDATORS, LARGE MAMMALS, EOOD HABITS, SPECIES COMPOSITION, NUTRIENTS, 1

22 AUTH BERGSTROM D.

DATE 1979.

TITL SMALL MAMMALS TRAEFIC IN TRUEFLES

PUBL FOR. RES. WEST JAN. 79:1-3. USDA FOR. SERV., PAC. NORTHWEST EOR. AND RANGE EXP. STN., PORTLAND, ORE.

ANNO SMALL MAMMALS' CONSUMPTION OF TRUEFLES MAY BE IMPORTANT IN SPREADING THE SPORES OF MYCORRHIZAL EUNGI WHICH ARE IMPORTANT KEYS SMALL MAMMALS, FOOD HABITS, 3, MYCORRHIZAL FUNGI

23 AUTH BERNARD S. R., BROWN K. F.

DATE 1977.

TITL DISTRIBUTION OF MAMMALS, REPTILES, AND AMPHIBIANS BY BLM PHYSIOGRAPHIC REGIONS AND A. W. KUCHLER'S ASSOCIATIONS FOR THE ELEVEN WESTERN STATES.

PUBL USDI-BLM TECH. NOTE 301, 169P.

ANNO INEORMATION ON HABITAT REOUIREMENTS, PHYSIOGRAPHIC REGIONS, ASSOCIATION NUMBERS, AND STATES WHERE EACH SPECIES OCCURS.

KEYS SMALL MAMMALS, PREDATORS, HABITAT, LIEE HISTORY, WESTERN U.S., 2

24 AUTH BISWELL H. H.

DATE 1963.

TITL RESEARCH IN WILDLAND FIRE ECOLOGY IN CALIFORNIA.

PUBL TALL TIMBERS EIRE ECOL. CONE. 2:63-97.

ANNO HARVEST MICE, PINYON MICE AND DEER MICE WERE TRAPPED IN UNTREATED AREAS BUT NO MICE WERE TRAPPED IN THE AREA OF THE PRESCRIBED BURN. SUGGESTS THAT BURNING DESTROYS COVER FOR HIDING AND LEAVES RODENTS VULNERABLE TO PREDATION BY OWLS.

KEYS HARVEST MOUSE, PINON MOUSE, DEER MOUSE, OWLS, PREDATION, POPULATION DENSITY, PONDEROSA PINE, MANZANITA, CALIFORNIA, SMALL MAMMALS, PRESCRIBED FIRE, 2

25 AUTH BLACK H. C., DIMOCK E. J., EVANS J., ROCHELLE J. A.

DATE 1979.

TITL ANIMAL DAMAGE TO CONIEEROUS PLANTATIONS IN OREGON AND WASHINGTON . PART 1. A SURVEY, 1963-1975.

PUBL RES. BULL. 25. ORE. STATE UNIV., SCH. OF FOR., CORVALLIS. ANNO DESCRIPTION OF ANIMAL DAMAGE TO CONIEEROUS PLANTATIONS IN OREGON AND WASHINGTON.

KEYS SMALL MAMMALS, LARGE MAMMALS, BIRDS, DAMAGE, OREGON, WASHINGTON, DOUGLAS-EIR, PONDEROSA PINE, 3

26 AUTH BLACK H. C., HOOVEN E. H.

DATE 1974 .

TITL RESPONSE OF SMALL MAMMAL COMMUNITIES TO HABITAT CHANGES IN WESTERN OREGON.

PUBL IN WILDLIFE AND FOREST MANAGEMENT IN THE PACIEIC NORTHWEST. P. 177-186. H. C. BLACK ED., PROC. 1973 SYMP. ORE. STATE UNIV., CORVALLIS.

ANNO DESCRIBES THE EEFECTS OF FIRE, LOGGING AND HERBICIDES ON SMALL MAMMAL POPULATIONS IN MATURE DOUGLAS-EIR AND MIXED CONIFER 
STANDS. SMALL MAMMALS RESPONDED TO HABITAT CHANGES CAUSED BY THESE DISTURBANCES ACCORDING TO THEIR HABITAT REOUIREMENTS.

KEYS SMALL MAMMALS, POST-EIRE SUCCESSION, SPECIES COMPOSITION, MORTALITY, SLASH FIRE, LOGGING, HABITAT, DEER MOUSE, SHREWS, VOLES, CHIPMUNKS, OREGON, DOUGLAS-FIR, HERBICIDE, POCKET GOPHERS, WILDEIRE, CLEARCUT, 1

27 AUTH BLACK H. C., TABER R. D.

DATE 1977.

TITL MAMMALS IN WESTERN CONIEEROUS EOREST ECOSYSTEMS: AN ANNOTATED BIBLIOGRAPHY .

PUBL BULL. NO. 2. CONIFEROUS FOREST BIOME ECOSYSTEM ANALYSIS STUDIES. US/INTERNATIONAL BIOLOGICAL PROGRAM. 199P.

ANNO ANNOTATED AND KEYWORDED BIBLIOGRAPHY OF MAMMALS IN WESTERN CONIEEROUS FORESTS.

KEYS SMALL MAMMALS, LARGE MAMMALS, PREDATORS, CONIEEROUS FOREST, BIBLIOGRAPHY, 1

28 AUTH BOCK J. H., BOCK C. E.

DATE 1978.

TITL RESPONSE OF BIRDS, SMALL MAMMALS, AND VEGETATION TO BURNING SACATON GRASSLANDS IN SOUTHEASTERN ARIZONA.

PUBL J. RANGE MANAGE. 31(4):295-300.

ANNO NUMBERS OF PEROMYSCUS WERE UNAFEECTED BY FIRE. COTTON RAT NUMBERS WERE REDUCED, BUT POCKET MICE AND KANGAROO RATS

INCREASED. RELATED THESE CHANGES TO FOOD HABITS. SEED EATERS INCREASED, VEGETATION EATERS DECREASED.

KEYS SMALL MAMMALS, BIRDS, GRASSLAND, PRESCRIBED FIRE, ARIZONA, GRAZING, FOOD HABITS, RAPTORS, COTTON RAT, POCKET MOUSE, KANGAROO RATS, DEER MOUSE, 2

29 AUTH BOCK J. H., BOCK C. E., MCKNIGHT J. R.

DATE 1976.

TITL A STUDY OF THE EFEECTS OF GRASSLAND FIRES AT THE RESEARCH RANCH IN SOUTHEASTERN ARIZONA.

PUBL ARIZONA ACADEMY OF SCIENCE $11(3): 49-57$.

ANNO SMALL MAMMALS SHOWED NO SIGNIEICANT INCREASE IN BURNED AREA AND IN SOME CASES DECREASED.

KEYS WILDEIRE, BIRDS, SMALL MAMMALS, GRASSLAND, ARIZONA, 2

30 AUTH BORRECCO J. E., BLACK H. C., HOOVEN E. F.

DATE 1979.

TITL RESPONSE OF SMALL MAMMALS TO HERBICIDE-INDUCED HABITAT CHANGES. PUBL NORTHWEST SCI. 53(2):97-106.

ANNO SPECIES COMPOSITION OF SMALL MAMMAL COMMUNITIES WAS ALTERED BY CONTROLLING THE HERBACEOUS VEGETATION. SPECIES PREEERRING GRASSY HABITATS - DEERMICE AND TROWBRIDGE SHREWS INCREASED AFTER TREATMENT WITH 2,4-D, VAGRANT SHREWS, OREGON VOLES AND PACIEIC JUMPING MICE DECREASED.

KEYS SMALL MAMMALS, HABITAT, HERBICIDE, CREEPING VOLE, DEER MOUSE, PACIEIC JUMPING MICE, TROWBRIDGE SHREW, VAGRANT SHREW, OREGON, 1

31 AUTH BRABANT A.

DATE 1922 .

TITL THE EIRE EIEND'S THREAT TO THE FUR TRADE.

PUBL CAN. FOR. MAG. 18(12):1204-1205.

ANNO FIRE CAUSES DISAPPEARANCE OF MARTEN.

KEYS MARTEN, FIRE, PREDATORS 
32 AUTH BRAND C. J., KEITH L. B.

DATE

TITL

PUBL

ANNO

1979 .

LYNX DEMOGRAPHY DURING A SNOWSHOE HARE DECLINE IN ALBERTA.

J. WILDL. MANAGE. 43(4):827-849.

DURING AN INTERVAL WHEN LYNX AND SNOWSHOE HARE POPULATIONS WERE DECLINING, THE BODY EAT OF LYNX DECLINED AND THE PERCENTAGE OE KITTENS IN THE POPULATION DECREASED.

KEYS PREDATORS, SMALL MAMMALS, LYNX, SNOWSHOE HARE, POPULATION DENSITY, ALBERTA, PREDATION, 1

33 AUTH BRAND C. J., KEITH L. B., EISCHER C. A.

DATE 1976.

TITL LYNX RESPONSES TO CHANGING SNOWSHOE HARE DENSITIES IN CENTRAL ALBERTA.

PUBL J. WILDL. MANAGE. $40: 416-428$.

ANNO WHEN THE POPULATION OE SNOWSHOE HARES WAS LOW, THERE WERE EEWER LYNX IN THE STUDY AREA AND THE EREQUENCY OE HARES IN THE LYNX DIET WAS LOWER THAN IN YEARS OE HARE ABUNDANCE.

KEYS LYNX, SNOWSHOE HARE, POPULATION DENSITY, PREDATORS, ALBERTA, SMALL MAMMALS, 3

34 AUTH BROADBROOKS H. E.

DATE 1970.

TITL POPULATIONS OF THE YELLOW-PINE CHIPMUNK, EUTAMIAS AMOENUS.

PUBL AM. MIDL. NAT. $83(2): 472-488$.

ANNO PINE SOUIRRELS, GOLDEN-MANTLED GROUND SOUIRRELS AND CHIPMUNKS, ALL DIURNAL AND SHARING HABITATS AND EOOD, LIVED TOGETHER

SUCCESSEULLY. CHIPMUNK POPULATION DENSITY CONTROLLED BY SPACING OF INDIVIDUALS AND PREDATORS.

KEYS SMALL MAMMALS, YELLOW-PINE CHIPMUNK, PREDATORS, LYNX, HABITAT, EOOD HABITS, POPULATION DENSITY, PREDATION, WASHINGTON, RED SQUIRREL, GOLDEN-MANTLED GROUND SQUIRREL, SELECTIVE CUT, RAPTORS, REPTILES, 3

35 AUTH BUCKNER J. L., LANDERS J. L.

DATE 1979.

TITL FIRE AND DISKING EEEECTS ON HERBACEOUS FOOD PLANTS AND SEED SUPPLIES.

PUBL J. WILDL. MANAGE. 43(3):807-811.

ANNO ANNUALS AND MOST PERENIALS WERE FAVORED BY DISKING. SEEDS ON DISKED AND ANNUALLY BURNED SITES WERE AVAILABLE TO SEED EATERS. SEEDLINGS ON DOUBLE DISKED SITES DEVELOPED WITH LITTLE COMPETITION BECAUSE WIREGRASS AND BRACKEN EERN HAD BEEN ELIMINATED, AND SEED PRODUCTION INCREASED $34 \%$ OVER THAT IN ANNUALLY BURNED WOODS.

KEYS SMALL MAMMALS, LARGE MAMMALS, BIRDS, PRESCRIBED EIRE, DISKING, EOOD HABITS, SEED， 1, GEORGIA， LONGLEAE PINE-WIREGRASS-BRACKEN EERN,

36 AUTH BUECH R. R., SIDERITS K., RADTKE R. E., SHELDON H. L., ELSING D.

DATE 1977.

TITL SMALL MAMMAL POPULATIONS AFTER A WILDEIRE IN NORTHEAST MINNESOTA.

PUBL USDA FOR. SERV. RES. PAP. NC-151. 8P. NORTH CENTRAL FOR. EXP. STN., ST. PAUL, MINN.

ANNO AETER A LARGE WILDEIRE ONLY 16 PERCENT AS MANY SMALL MAMMALS WERE IN THREE FOREST COMMUNITIES THAT HAD BURNED AS WERE IN COMPARABLE UNBURNED AREAS. THE RED-BACKED VOLE WAS THE MOST 
AEEECTED. DEER MICE APPEARED TO HAVE IMMIGRATED INTO THE BURNED AREA.

KEYS RED-BACKED VOLES, DEER MOUSE, MASKED SHREW, ROCK VOLE, LEAST CHIPMUNK, POPULATION DENSITY, SPECIES DIVERSITY, MINNESOTA, SMALL MAMMALS, WILDEIRE, I

37 AUTH BUECHNER H. K.

DATE 1942 .

TITL INTERRELATIONSHIPS BETWEEN THE POCKET GOPHER AND LAND USE.

PUBL J. MAMMAL. 23(3):346-348.

ANNO OVERGRAZING GREATLY INCREASED THE NUMBER OE POCKET GOPHERS.

KEYS SMALL MAMMALS, POCKET GOPHERS, GRAZING, POPULATION DENSITY, GRASSLAND， TEXAS, 2

38 AUTH BURNS S.

DATE NO DATE.

TITL MANAGING SNAGS EOR WILDLIEE HABITAT. COORDINATING GUIDELINES EOR WILDLIEE HABITAT NO 2.

PUBL USDA EOR. SERV. BITTERROOT NATL. EOREST, NORTHERN REGION, MISSOULA, MONT.

ANNO RECOMMENDATIONS FOR PRESERVING SNAGS FOR WILDLIEE HABITAT.

KEYS SNAGS, BIRDS, SMALL MAMMALS, HABITAT, 3

39 AUTH BURTON D. H., BLACK H. C.

DATE 1978.

TITL EEEDING HABITS OE MAZAMA POCKET GOPHERS IN SOUTH-CENTRAL OREGON.

PUBL J. WILDL. MANAGE. 42(2):383-390.

ANNO MAZAMA POCKET GOPHERS PREEERRED SUCCULENT PLANTS. GRASSES WERE HEAVILY UTILIZED WHEN EORBS WERE NOT AVAILABLE. PONDEROSA PINE WERE EATEN IN THE WINTER, BUT WERE A VERY MINOR PART OE THE DIET. SUGGESTS HABITAT MODIEICATION TO CONTROL POCKET GOPHER DAMAGE TO TREE REGENERATION.

KEYS SMALL MAMMALS, WESTERN POCKET GOPHER, OREGON, EOOD HABITS, 2

40 AUTH CHEW R. M., BUTTERWORTH B. B., GRECHMAN R.

DATE 1958.

TITL THE EEFECTS OE FIRE ON THE SMALL MAMMAL POPULATIONS OF THE CHAPARRAL.

PUBL J. MAMMAL. $40(2): 253$.

ANNO GIVES NUMBERS OF SMALL MAMMAL CARCASSES EOUND IN CANYON AETER CHAPARRAL EIRE. APPARENT CAUSE OE DEATH WAS ASPHYXIATION OR HEAT PROSTRATION.

KEYS SMALL MAMMALS, MORTALITY, CHAPARRAL, CALIEORNIA, WILDEIRE, 2

4 I AUTH CLARK T. W., CAMPBELL T. M.

DATE 1979.

TITL POPULATION ORGANIZATION AND REGULATORY MECHANISMS OE PINE MARTEN IN GRAND TETON NATIONAL PARK, WYOMING.

PUBL IN PROC. IST CONE. ON SCI. RES. IN THE NATL. PARKS. VOL. I P. 293-295. R. M. LINN ED. USDI NATL. PARK SERV. TRANS. AND PROC. SERIES NO. 5 .

ANNO STUDY ON UNDISTURBED MARTEN POPULATION IN GRAND TETON NATIONAL PARK AND AN ECOLOGICALLY SIMILILAR AREA ON THE TETON NATIONAL EOREST THAT WAS SUBJECT TO LOGGING. NO CHANGES IN TRAP UTILIZATION OR MARTEN HOME RANGES WERE OBSERVED AS A RESULT OF THE LOGGING OPERATIONS.

KEYS PREDATORS, MARTEN, GRAND TETON NATL. PARK, PREDATION, WYOMING, RODENTS, LOGGING, I, POPULATION DENSITY, VEGETATION STRUCTURE 
42 AUth CLEARY B. D., GREAVES R. D., HERMANn R. K.

DATE 1978.

TITL REGENERATING OREGON'S EORESTS.

PUBL OREGON STATE UNIV. EXTENSION SERVICE, CORVALLIS, ORE. 203 P.

ANNO SECTION ON DESTRUCTIVE IMPACTS OE MAMMALS ON REEORESTATION.

KEYS SMALL MAMMALS, LARGE MAMMALS, DAMAGE, 3, OREGON

43 AUTH CLOTHIER R. R.

DATE 1955.

TITL CONTRIBUTION TO THE LIEE HISTORY OE VAGRANT SHREW:

PUBL J. MAMMAL. 36(2):214-221.

ANNO LIEE HISTORY OE VAGRANT SHREW. THEY ARE MOST COMMON IN DAMP

SITUATIONS, NEAR WATER. FOOD WAS MAINLY INSECTS, EARTHWORMS, AND OTHER SMALL INVERTEBRATES.

KEYS SMALL MAMMALS, VAGRANT SHREW, EOOD HABITS, HABITAT, MONTANA, 3

44 AUTH COOK S. E. JR.

DATE 1959.

TITL THE EEEECTS OF EIRE ON A POPULATION OF SMALL RODENTS.

PUBL ECOLOGY 40:102-108.

ANNO THE REDUCTION OE COVER RESULTING FROM EIRE WAS CONSIDERED TO BE THE MAJOR EACTOR LIMITING THE RECOVERY OE MICE. IN THE SECOND YEAR AETER EIRE, THE INCREASE OE SEED PRODUCING ANNUALS EAVORED SEED EATING MICE.

KEYS SMALL MAMMALS, POPULATION DENSITY, GRASSLAND, BRUSH-GRASS, CALIEORNIA, WILDEIRE, 2, HABITAT, EOOD HABITS

45 AUTH COSTA R., EFOLLIOTT P. E., PATTON D. R.

DATE 1976.

TITL COTTONTAIL RESPONSES TO EOREST MANAGEMENT IN SOUTHWESTERN PONDEROSA PINE.

PUBL USDA EOR. SERV. RES. NOTE-RM 330. 4P. ROCKY MT. EOR. AND RANGE EXP. STN., ET. COLLINS, COLO.

ANNO WHEN MANAGING PONDEROSA PINE EOR TIMBER PRODUCTION USING SHELTERWOOD OR GROUP SELECTION, COTTONTAILS CAN BE INCREASED BY ENCOURAGING DENSE REGENERATION. IN CLEARCUTS, WINDROWING SLASH AND ENCOURAGING HERBACEOUS AND SHRUBBY GROWTH WILL INCREASE COTTONTAIL USE.

KEYS SMALL MAMMALS, COTTONTAIL RABBIT, CLEARCUT, PONDEROSA PINE, ARIZONA, LOGGING, 2, HABITAT

46 AUTH COWAN I. MCT., MACKAY R. H.

DATE 1950.

TITL EOOD HABITS OE THE MARTEN (MARTES AMERICANA) IN THE ROCKY MOUNTAIN REGION OE CANADA.

PUBL CAN. EIELD-NAT. 64(3):100-104.

ANNO MARTEN USED RED-BACKED VOLES MORE THAN ANY OTHER FOOD ITEM. SUGGESTS THAT VARYING HARE AND GROUSE 'IOYEAR' CYCLES DO NOT AEEECT MARTEN REPRODUCTION, BECAUSE THE MARTEN PREEERS A DIET OE VOLES.

KEYS MARTEN, FOOD HABITS, PREDATION, ALBERTA, POPULATION DENSITY, RED-BACKED VOLES, 2, PREDATORS, SMALL MAMMALS

47 AUTH COWLES R. B.

DATE 1967.

TITL FIRE SUPPRESSION, FAUNAL CHANGES AND CONDOR DIETS.

PUBL TALL TIMBERS EIRE ECOL. CONE. 7:217-244.

ANNO SUPPRESSION OE FIRE AND RESULTANT BRUSH FIELDS ON CALIEORNIA MOUNTAIN SIDES HAS CAUSED CALIEORNIA CONDORS TO SWITCH EROM A 
PREEERRED DIET OF SMALL MAMMALS, ESPECIALLY RABBITS, TO CARCASSES OF LARGE HERBIVORES. SUGGESTS A CALCIUM DEFICIENCY HAS RESULTED EROM THE LACK OF SMALL BONES IN THE CONDORS' DIET. KEYS RABBITS, CALIFORNIA, CALIEORNIA CONDOR, PREDATION, CHAPARRAL, CALIEORNIA, POST-EIRE SUCCESSION, SMALL MAMMALS, BIRDS, 3

48 AUTH CROUCH G. L.

DATE 1976.

TITL WILD ANIMAL DAMAGE TO FORESTS IN THE UNITED STATES AND CANADA. PUBL IN XVI IUERO WORLD CONGRESS PROC. DIV. II, NORWAY P. 468-478. ANNO DESCRIBES DAMAGE TO FOREST TREES BY DIFEERENT KINDS OF WILDLIEE.

KEyS SMALL MAMMALS, LARGE MAMMALS, BIRDS, DAMAGE, U.S., CANADA, 3, RAPTORS

49 AUTH CROUCH G. L.

DATE 1979.

TITL ATRAZINE IMPROVES SURVIVAL AND GROWTH OF PONDEROSA PINE THREATENED BY VEGETATIVE COMPETITION AND POCKET GOPHERS.

PUBL EOR. SCI. 25(1):99-111.

ANNO ATRAZINE WAS SUCCESSEULLY USED TO REDUCE COMPETITIVE PLANT COVER AND POCKET GOPHER FOOD SUPPLY. FALL APPLICATIONS WERE MORE SUCCESSEUL THAN SPRING APPLICATIONS.

KEYS SMALL MAMMALS, POCKET GOPHERS, FOOD HABITS, PONDEROSA PINE, OREGON, HERBICIDE, 3

50 AUTH DAVIS P. R.

DATE 1976.

TITL RESPONSE OF VERTEBRATE FAUNA TO FOREST FIRE AND CLEARCUTTING IN SOUTH CENTRAL WYOMING.

PUBL USDA FOR. SERV. AND UNIV. OE WYOMING COOP AGREEMENTS NOS. 16-391-CA AND 16-464-CA. 94P.

ANNO COMPARED EFEECTS OF CLEARCUTS AND WILDEIRE ON WILDLIFE. REASONS FOR DIFEERENCES WERE DETERMINED. RECOMMENDATIONS WERE MADE TO MAKE CLEARCUTS MORE CLOSELY RESEMBLE EIRE. CLEARCUTS SUPPORTED MORE SMALL MAMMALS THAN FORESTED AREAS OR BURNS. IT WAS RECOMMENDED THAT SOME LOGGING RESIDUE BE LEET FOR SMALL MAMMAL ESCAPE COVER. LEAST CHIPMUNKS AND GOLDEN-MANTLED GROUND SQUIRELS WERE MORE NUMEROUS IN BURNED THAN CLEARCUT AREAS, DEER MICE WERE MORE ABUNDANT IN BURNED AND CLEARCUT AREAS THAN FORESTED AREAS, AND RED-BACKED VOLES WERE MOST ABUNDANT IN EORESTED AREAS.

KEYS LARGE MAMMALS, SMALL MAMMALS, BIRDS, WILDEIRE, CLEARCUT, WYOMING, LODGEPOLE PINE, LEAST CHIPMUNK, GOLDEN-MANTLED GROUND SQUIRREL, DEER MOUSE, RED-BACKED VOLES, BIBLIOGRAPHY

51 AUTH DE VOS A.

DATE 1951.

TITL OVERELOW AND DISPERSAL OF MARTEN AND EISHER EROM WILDLIEE REEUGES.

PUBL J. WILDL. MANAGE. 15(2):164-175.

ANNO POINTS OUT THE VALUE OE WILDLIEE REFUGES FOR PROTECTION AND AS CENTERS OF DISPERSAL EOR EUR-BEARERS.

KEYS PREDATORS, MARTEN, FISHER, POPULATION DENSITY, MIGRATION, 3

52 AUTH DE VOS A.

DATE 1951.

TITL RECENT EINDINGS IN EISHER AND MARTEN ECOLOGY AND MANAGEMENT.

PUBL TRANS. N. AM. WILDL. CONE. 16:498-507. 
ANNO EISHER APPEAR TO ADAPT BETTER TO EARLIER SUCCESSIONAL STAGES THAN MARTEN, BUT BOTH ARE RARE IN RECENTLY LOGGED OR BURNED-OVER AREAS. FISHER FOOD FOR THE WINTER CONSISTED OF SNOWSHOE HARE, PORCUPINE, EISH, AND MICE.

KEYS PREDATORS, MARTEN, FISHER, SMALL MAMMALS, LOGGING, EIRE, 2, SNOWSHOE HARE, MICE, PORCUPINE

53 AUTH DEBYLE N. V.

DATE 1981.

TITL CLEARCUTTING AND FIRE IN THE LARCH-EIR EORESTS OF WESTERN MONTANA--A MULTIEACETED RESEARCH SUMMARY.

PUBL USDA FOR. SERV., GEN. TECH. REP. INT-99. INTERMT. FOREST AND RANGE EXP. STN., OGDEN, UTAH.

ANNO DISCUSSES EFEECT OF BROADCAST BURNING ON SMALL MAMMALS AND THE IMPLICATIONS FOR TREE REGENERATION.

KEYS SMALL MAMMALS, FOOD HABITS, CLEARCUT, POPULATION DENSITY, BROADCAST EIRE， 3

54 AUTH DICE L. R.

DATE 1925.

TITL A SURVEY OF THE MAMMALS OF CHARLEVOIX COUNTY, MICHIGAN, AND VICINITY.

PUBL UNIV. OF MICH. MUS. ZOOL., OCCAS. PAP. 159:1-33.

ANNO FIRE HAS DISASTEROUS EFEECT ON SMALL MAMMALS BECAUSE OF THE DESTRUCTION OE THEIR HABITAT AND FOOD. MARTEN AND FISHER WHICH ARE DEPENDANT ON SMALL MAMMALS FOR FOOD ARE ALSO ELIMINATED BY EIRE.

KEYS SMALL MAMMALS, MICHIGAN, LOGGING, FIRE, PREDATORS, MARTEN, EISHER， 2

55 AUTH DIMOCK E. J. II.

DATE 1974.

TITL ANIMAL POPULATIONS AND DAMAGE.

PUBL IN ENVIORNMENTAL EFEECTS OF FOREST RESIDUES MANAGEMENT IN THE PACIEIC NORTHWEST. O. P. CRAMER, ED. P.0-1-0-27. USDA FOR. SERV. GEN. TECH. REP. PNW-24, PAC. NORTHWEST FOR. AND RANGE EXP. STN., PORTLAND, ORE.

ANNO MOST RESIDUE TREATMENTS EURTHER ENHANCE HABITATS ALREADY IMPROVED FOR PROBLEM ANIMALS BY TIMBER HARVESTING. TREATMENTS THAT MODIEY RESIDUES THE LEAST APPEAR MOST PROMISING FOR ATTAINING TIMBER, RANGE, AND WILDLIEE PRODUCTION GOALS WITH MINIMUM DAMAGE EROM ANIMALS.

KEYS SMALL MAMMALS, LOGGING, RESIDUE TREATMENTS, HABitAT, DAMAGE, LARGE MAMMALS, BIRDS, PRESCRIBED FIRE

56 AUTH EADIE W. R.

DATE 1953.

TITL RESPONSE OE MICROTUS TO VEGETATIVE COVER.

PUBL J. MAMMAL . 34:263-264.

ANNO MICROTUS AVOIDED AREAS OF SPARCE VEGETATION IN MEADOW HABITAT. SUGGESTS REDUCTION OF GROUND VEGETATION IN ORCHARDS WOULD MAKE THEM LESS HABITABLE EOR VOLES.

KEYS SMALL MAMMALS, MEADOW VOLE, VEGETATION STRUCTURE, POPULATION DENSITY, HABITAT, 1

57 AUTH EASTMAN J.

DATE 1976.

TITL LURE OF THE BURN.

PUBL NAT. WILDL. 14(5):10. 
ANNO BRIEELY DESCRIBES SEVERAL BENEEICIAL EFEECTS OE EIRE ON WI LDLIEE.

KEYS LARGE MAMMALS, SMALL MAMMALS, BIRDS, CALIEORNIA CONDOR, MORTALITY, EOOD HABITS, HABITAT, WILDEIRE, 2

58 AUTH EDGERTON P. J., THOMAS J. W.

DATE 1977.

TITL IMPACTS OE SILVICULTURE ON WILDLIEE HABITATS IN THE BLUE MOUNTAINS.

PUBL IN INTEGRATION OE EOREST RESOURCE MANAGEMENT IN THE BLUE MOUNTAINS, J. HERBST, ED., P.61-63. MAR. 1977. LA GRANDE, ORE. $66 \mathrm{P}$.

ANNO DISCUSSES METHODS OE MODIEYING WILDLIEE HABITAT THROUGH SILVICULTURAL TECHNIOUES. EMPHASIS ON STRUCTURE OF VEGETATION.

KEYS HABITAT, LOGGING, OREGON, BIRDS, VEGETATION STRUCTURE, 2

59 AUTH EDWARDS R. Y.

DATE 1954.

TITL FIRE AND THE DECLINE OF A MOUNTAIN CARIBOU HERD.

PUBL J. WILDL. MANAGE. 18(4):521-526.

ANNO DISCUSSES THE LONG TERM EFEECTS OF CATASTROPHIC EIRE ON WILDLIEE. CLIMAX EOREST SPECIES DECLINED, SPECIES FAVORED BY EARLY SUCCESSION AND THEIR PREDATORS INCREASED.

KEYS LARGE MAMMALS, PREDATORS, SMALL MAMMALS, CARIBOU, MOOSE, MULE DEER, MARTEN, MOUNTAIN LION, COYOTE, WOLVERINE, BEAVER, EOOD HABITS, POPULATION DENSITY, BRITISH COLUMBIA, LONG TERM EIRE EFEECTS, WILDEIRE, 1

60 AUTH ELLISON L.

DATE 1946.

TITL THE POCKET GOPHER IN RELATION TO SOIL EROSION ON MOUNTAIN RANGE .

PUBL ECOLOGY 27(2):101-114.

ANNO ALTHOUGH POCKET GOPHERS ARE RESPONSIBLE FOR DOWNHILL DISPLACEMENT OF SOIL, OVERGRAZING IS THE PRIMARY CAUSE OF EROSION. GOPHERS INCREASED IN HEAVILY GRAZED AREAS BECAUSE OF THE INCREASE OE DEEP ROOTED OR BULBOUS FORBS. THE GOPHERS ACTUALLY IMPROVE SOIL AERATION AND IMPROVE WATER INEILTRATION.

KEYS SMALL MAMMALS, POCKET GOPHERS, POPULATION DENSITY, SOIL EROSION, UTAH, 2, GRAZING

61 AUTH ELLISON L., ALDOUS C. M.

DATE 1952 .

TITL INELUENCE OF POCKET GOPHERS ON VEGETATION OF SUBALPINE GRASSLAND IN CENTRAL UTAH.

PUBL ECOLOGY 33(2):177-186.

ANNO RESULTS OF A 9 YEAR STUDY WHERE GOPHERS WERE REMOVED FROM HALE OE THE STUDY AREA INDICATED THAT POCKET GOPHERS IMPROVE SOIL AERATION AND PROBABLY CAUSE AN INCREASE IN VEGETATION INSPITE OE WHAT THEY CONSUME. .

KEYS SMALL MAMMALS, POCKET GOPHERS, POPULATION DENSITY, UTAH, SOIL, GRASSLAND, HABITAT, FIRE, GRAZING, SOIL COMPACTION, 2

62 AUTH EVANS K. E., PROBASCO G. E.

DATE 1977.

TITL WILDLIEE OF THE PRAIRES AND PLAINS.

PUBL USDA FOR. SERV. GEN. TECH. REP. NC-29, 18P. NORTH CENT. FOR. EXP. STN. ST., PAUL, MINN. 
ANNO DISCUSSION OF WILDLIFE RESOURCES AND HABITAT MANAGEMENT OF GRASSLANDS IN THE U.S.

KEYS SMALL MAMMALS, LARGE MAMMALS, PREDATORS, AMPHIBIANS, REPTILES, GRASSLAND, HABITAT, BIRDS, 3

63 AUTH FALA R. A.

DATE 1975.

TITL EFFECTS OF PRESCRIBED BURNING ON SMALL MAMMAL POPULATIONS IN A MIXED-OAK CLEARCUT.

PUBL J. FOR. 73(9):586-587.

ANNO PRESCRIBED BURNING IN A MIXED-OAK CLEARCUT IN PENNSYLVANIA RESULTED IN A REDUCTION OF HERBIVOROUS SPECIES (VOLES), HOWEVER INSECTIVOROUS AND SEED EATING DEER MICE BECAME ESTABLISHED WITHIN ONE MONTH. CONCLUDED FIRE WAS ADVANTAGEOUS FOR SITE PREPARATION WHEN TREES ARE TO BE PLANTED BECAUSE IT REDUCED HERBIVOROUS SMALL MAMMALS.

KEYS SMALL MAMMALS, DEER MOUSE, RED-BACKED VOLES, MEADOW VOLE, POPULATION DENSITY, POST-FIRE SUCCESSION, OAK, PENNSYLVANIA, FOOD HABITS, PRESCRIBED FIRE, CLEARCUT, 1

64 AUTH FISHER E. L., HURLEY J. F.

DATE 1978.

TITL FUELS, MANAGEMENT AND WILDLIFE.

PUBL USDA FOR. SERV. COORDINATION GUIDELINES FOR WILDLIFE HABITATS, NO. 10. 14P. CALIFORNIA, REGION.

ANNO DESCRIBES METHODS OF MANAGING FUELS TO IMPROVE WILDLIFE HABITAT.

KEYS SMALL MAMMALS, LARGE MAMMALS, BIRDS, FISH, PREDATORS, FUELS, HABITAT MANAGEMENT, SLASH, PRESCRIBED FIRE, 2

65 AUTH FISHER J. L., CROSS S. P.

DATE 1979.

TITL BATTERY-LIGHT TRACKING AS A TECHNIOUE FOR STUDYING SMALL NOCTURAL MAMMAL MOVEMENTS.

PUBL NORTHWEST SCI. 53(2):90-93.

ANNO DESCRIBES A TECHNIQUE FOR MONITORING SMALL MAMMAL MOVEMENTS AT NIGHT USING A BATTERY-LIGHT PACKET ATTACHED TO MOUSE.

KEYS SMALL MAMMALS, MOVEMENTS, 2, MICE

66 AUTH FITCH H. S.

DATE 1947.

TITL PREDATION BY OWLS IN THE SIERRA FOOTHILLS OF CALIFORNIA. PUBL CONDOR 49:137-151.

ANNO ANALYSIS OF FOOD HABITS OF OWLS PREYING ON SMALL MAMMALS.

KEYS SMALL MAMMALS, RAPTORS, OWLS, CALIFORNIA, PREDATION, GREAT HORNED OWL, BARN OWL, POCKET GOPHERS, 3

67 AUTH FITCH H. S.

DATE 1954.

TITL SEASONAL ACCEPTANCE OF BAIT BY SMALL MAMMALS.

PUBL J. MAMMAL. 35:39-47.

ANNO SMALL MAMMAL POPULATIONS VARY IN THEIR SUSCEPTIBILITY TO TRAPPING DUE TO SEASONAL CHANGES IN FOOD AVAILABILITY, WEATHER CONDITIONS AND OTHER FACTORS.

KEYS SMALL MAMMALS, FOOD HABITS, POPULATION DENSITY, TRAPPING, 2 
68 AUTH EOGEL R. D., TRAPPE J. M.

DATE 1978.

TITL EUNGUS CONSUMPTION (MYCOPHAGY) BY SMALL MAMMALS.

PUBL NORTHWEST SCI. 52:1-31.

ANNO A REVIEW OE THE LITERATURE ON SMALL MAMMAL FOOD HABITS, DISCUSSION OF THE EOOD VALUE OE EUNGI, AND THE SIGNIFICANCE OE THE INTERDEPENDANCE OF SMALL MAMMALS AND EUNGI TO THE FOREST ECOSYSTEM.

KEYS SMALL MAMMALS, FOOD HABITS, BIBLIOGRAPHY, FUNGI, 2

69 AUTH FOWELLS H. A., SCHUBERT G. H.

DATE 1951.

TITL RECENT DIRECT SEEDING TRIALS IN THE PINE REGION OF CALIFORNIA.

PUBL USDA FOR. SERV. RES. NOTE NO. 78, 9P. CALIF. FOREST AND RANGE EXP. STN.

ANNO BURNING DID NOT PROTECT SEED PLANTINGS EROM RODENTS. BROADCAST POISONING OEFERED ONLY TEMPORARY RODENT CONTROL.

KEYS SMALL MAMMALS, FIRE, FOOD HABITS, 2, POISONS

70 AUTH EOX J. E.

DATE 1978.

TITL EOREST FIRES AND THE SNOWSHOE HARE - CANADA LYNX CYCLE.

PUBL OECOLOGIA (BERL.) 31:349-374.

ANNO AUTHOR SUPPORTS HYPOTHESIS OE POST-EIRE SECONDARY SUCCESSION TO ACCOUNT FOR SNOWSHOE HARE - CANADA LYNX PELT CYCLES, USING INEORMATION EROM FUR TRAPPING, EIRE HISTORY, PLANT ECOLOGY AND ANIMAL PHYSIOLOGY.

KEYS SNOWSHOE HARE, LYNX, POST-EIRE SUCCESSION, POPULATION DENSITY, FOOD HABITS, SMALL MAMMALS, PREDATORS, WILDEIRE, 2, CANADA

71 AUTH ERENZEL R. W., STARKEY E. E., BLACK H. C.

DATE 1979.

TITL EEFECTS OE PRESCRIBED BURNING ON SMALL MAMMAL COMMUNITIES IN THE LAVA BEDS NATIONAL MONUMENT, CALIFORNIA

PUBL IN PROC. IST CONE. ON SCI. RES. IN THE NATL. PARKS VOL. II. P. 287-292, R. M. LINN ED. USDI NATL. PARK SERV. TRANS. AND PROC. NO. 5. 1979 .

ANNO PRESCRIBED EIRE IN SAGEBRUSH-BUNCHGRASS AND IN CHEATGRASS DID NOT HAVE AN IMMEDIATE EEFECT ON THE MAJOR SMALL MAMMAL SPECIES.

KEYS SMALL MAMMALS, PRESCRIBED EIRE, LAVA BEDS NATIONAL MONUMENT, CALIFORNIA， SAGEBRUSH-GRASS, CHEATGRASS, DEER MOUSE, HEERMANN KANGAROO RAT, GREAT BASIN POCKET MOUSE, MONTANE VOLE, 2

72 AUTH ERIDAY G. P.

DATE 1978.

TITL VEGETATIVE STRUCTURE AND MAMMALIAN UTILIZATION ON A FOREST-EIELD TRANSITION AND ITS ADJACENT HABITATS.

PUBL PH.D. DISSERTATION. MICH. STATE UNIV., EAST LANSING. 74P.

KEYS SMALL MAMMALS, WHITE-FOOTED MOUSE, EASTERN CHIPMUNK, FOX SQUIRREL, RED SOUIRREL, VEGETATION STRUCTURE, HABITAT, FOREST-FIELD TRANSITION, 2

73 AUTH GARMAN E. H., ORR-EWING A. L.

DATE 1949.

TITL DIRECT-SEEDING EXPERIMENTS IN THE SOUTHERN COASTAL REGION OF BRITISH COLUMBIA.

PUBL BRIT. COL. FOR. SERV., TECH. PUBL. T 31.

ANNO RAPID INCREASE IN SMALL MAMMAL POPULATION 2 WEEKS AFTER SLASH EIRE. 


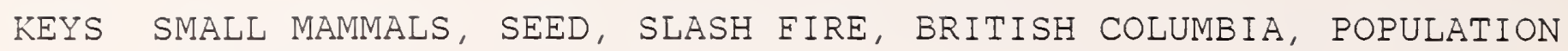
DENSITY, 2

74 AUTH GASHWILER J. S.

DATE 1959.

TITL SMALL MAMMAL STUDY IN WEST-CENTRAL OREGON.

PUBL J. MAMMAL 40:128-138.

ANNO SMALL MAMMAL POPULATIONS WERE STUDIED IN LOGGED AND BURNED

DOUGLAS-FIR. DEER MICE INCREASED AFTER LOGGING. AFTER BURNING

THEY INCREASED 2-3 TIMES ABOVE DENSITIES IN VIRGIN EOREST.

RED-BACKED VOLES INCREASED AETER LOGGING, BUT DISAPPEARED AETER

FIRE. CHIPMUNKS DECREASED AETER LOGGING AND AETER FIRE.

KEYS SMALL MAMMALS, DEER MOUSE, RED-BACKED VOLES, CHIPMUNKS, CLEARCUT, DOUGLAS-FIR, PACIFIC NORTHWEST, POPULATION DENSITY, MORTALITY, SLASH FIRE, 1

75 AUTH GASHWILER J. S.

DATE 1965.

TITL TREE SEED ABUNDANCE VS. DEER MOUSE POPULATIONS IN DOUGLAS-EIR CLEARCUTS.

PUBL PROC. SOC. AM. EOR., 1965:219-222.

ANNO SPRING POPULATIONS OF DEER MICE SEEM TO BE AEFECTED BY FACTORS OTHER THAN SEED ABUNDANCE. FALL POPULATIONS DID NOT RESPOND TO CURRENT SEED CROPS, BUT SHOWED A POSITIVE RESPONSE TO MODERATE OR GOOD SEED CROPS FROM THE PRECEEDING YEAR. SIZE OE SPRING POPULATION HAS VERY LITTLE INELUENCE ON THE SIZE OF FALL POPULATIONS AND VICE VERSA.

KEYS SMALL MAMMALS, DEER MOUSE, FOOD HABITS, SEED, DOUGLAS-Fir, CLEARCUT, DAMAGE, PACIEIC NORTHWEST, 2

76 AUTH GASHWILER J. S.

DATE 1967.

TITL CONIEER SEED SURVIVAL IN A WESTERN OREGON CLEARCUT.

PUBL ECOLOGY $48(3): 431-438$.

ANNO SMALL MAMMALS AND BIRDS CAUSED 63\% OF DOUGLAS-EIR SEED LOSS ON CLEARCUT, AND 16\% OF WESTERN HEMLOCK SEED LOSS.

KEYS SMALL MAMMALS, BIRDS, CLEARCUT, OREGON, SEED, FOOD HABITS, DOUGLAS-FIR, 2

77 AUTH GASHWILER J. S.

DATE 1969.

TITL DEER MOUSE REPOPULATION OF A POISONED DOUGLAS-FIR CLEARCUT.

PUBL J. EOR. $67(7): 494-497$.

ANNO POISONED BAIT WAS EFEECTIVE FOR 38 DAYS. IMMIGRATION OCCURRED 15-19 DAYS LATER. IN 5 TO 7 MONTHS THE POPULATION WAS BACK TO PREVIOUS LEVELS.

KEYS SMALL MAMMALS, DEER MOUSE, POISONS, DOUGLAS-Fir, ClEARCUT, POPULATION DENSITY, MIGRATION, OREGON, 2

78 AUTH GASHWILER J. S.

DATE 1970.

TITL FURTHER STUDY OF CONIEER SURVIVAL IN A WESTERN OREGON CLEARCUT. PUBL ECOLOGY 51(5):849-854.

ANNO BIRDS, CHIPMUNKS, SHREWS AND MICE ACCOUNT FOR A LARGE PERCENTAGE OF THE LOSS OF NATURALLY DISSEMINATED SEED ON A CLEAR CUT.

KEYS SMALL MAMMALS, OREGON, CLEARCUT, SEED, FOOD HABITS, DOUGLAS-EIR, WESTERN HEMLOCK, WESTERN RED-CEDAR, BIRDS, MICE, SHREWS, CHIPMUNKS, 1 
AUTH GASHWILER J.S.

DATE 1970.

TITL PLANT AND ANIMAL CHANGES ON A CLEARCUT IN WEST-CENTRAL OREGON. PUBL ECOLOGY 51(6): 1018-1026.

ANNO PLANT AND MAMMAL CHANGES IN A VIRGIN EOREST AND A BURNED CLEARCUT WERE STUDIED FOR 10 YEARS. DESCRIBES CHANGES IN SMALL MAMMAL POPULATIONS.

KEYS SMALL MAMMALS, CLEARCUT, DOUGLAS-EIR, OREGON, SPECIES COMPOSITION, POPULATION DENSITY, POST-EIRE SUCCESSION, DEER MOUSE, TOWNSEND'S CHIPMUNK, CREEPING VOLE, SNOWSHOE HARE, SHREWS, ERMINE, RED-BACKED VOLES, FLYING SOUIRRELS, DOUGLAS' SOUIRRELS, CALIFORNIA GROUND SOUIRREL, MIGRATION, SLASH FIRE, 1

80 AUTH GASHWILER J. S., ROBINETTE W. L., MORRIS D. W.

DATE 1960.

TITL EOODS OF BOBCATS IN UTAH AND EASTERN NEVADA.

PUBL J. WILDL. MANAGE. 24(2):226-229.

ANNO REPORTS STOMACH CONTENT ANALYSIS OE BOBCATS KILLED BY HUNTERS. HARES AND RABBITS WERE THE CHIEE EOOD ITEM.

KEYS PREDATORS, SMALL MAMMALS, BOBCAT, NEVADA, UTAH, BLACK-TAILED JACK RABBIT, RABBITS, PORCUPINE, DEER MOUSE, 2

81 AUTH GETZ L. L.

DATE 1968.

TITL INELUENCE OE WATER BALANCE AND MICROCLIMATE ON THE LOCAL DISTRIBUTION OE THE RED-BACKED VOLE AND WHITE-EOOTED DEER MOUSE.

PUBL ECOLOGY 49:276-286.

ANNO RESTRICTION OF RED-BACKED VOLE HABITAT AS COMPARED TO THAT OE THE WHITE-EOOTED MOUSE WAS RELATED TO THE AVAILABILITY OE WATER, RATHER THAN OTHER ASPECTS OF THE MICROCLIMATE.

KEYS SMALL MAMMALS, RED-BACKED VOLES, WHITE-FOOTED MOUSE, MICROCLIMATE, MOISTURE REOUIREMENTS, NEW ENGLAND, UPLAND WOODS, SWAMPS, 1

82 AUTH GIVENS L. S.

DATE 1962.

TITL USE OF EIRE ON SOUTHEASTERN WILDLIEE REEUGES.

PUBL TALL TIMBERS FIRE ECOL. CONE. 1:121-126.

ANNO BURNING AT LEAST EVERY OTHER YEAR IS NECESSARY IN COASTAL MARSHES TO MAINTAIN EARLY SUCCESSIONAL STAGES AND PREEERRED EOODS OE MUSKRATS, BLUE AND SNOW GEESE.

KEYS MUSKRAT, BLUE GOOSE, SNOW GOOSE, COASTAL MARSHES, SOUTHEAST, SMALL MAMMALS, BIRDS, PRESCRIBED FIRE, 3

83 AUTH GODEREY G. K.

DATE 1955.

TITL OBSERVATIONS ON THE NATURE OF THE DECLINE IN NUMBERS OF TWO MICROTUS POPULATIONS.

PUBL J. MAMMAL. 36(2):209-214.

ANNO EXAMINES POSSIBLE CAUSES OE POPULATION ELUCTUATIONS OE EIELD VOLES. FINDING NO ENVIORNMENTAL CAUSES, SUPPORTS HYPOTHESIS THAT IN THE YEAR OE THE POPULATION CRASH, OVER-WINTERING ANIMALS ARE ABNORMAL EROM BIRTH AS A RESULT OE INTRASPECIEIC STRIEE THE PREVIOUS BREEDING SEASON.

KEYS VOLES, POPULATION DENSITY, ENGLAND, 3 
84 AUTH GRAHAM S. A.

DATE 1928.

TITL INELUENCE OF SMALL MAMMALS AND OTHER EACTORS UPON THE LARCH SAWELY SURVIVAL IN THE LAKE STATES.

PUBL J. ECON. ENTOMOL.

ANNO MICE ARE IMPORTANT IN THE DESTRUCTION OE LARCH SAWELY PREPUPAE. WHERE MOUSE POPULATIONS ARE HIGH, DESTRUCTION OF SAWELIES IS HIGH. VOLES ATE MORE SAWELY PREPUPAE THAN THE INSECTIVOROUS SHREWS.

KEYS SMALL MAMMALS, FOOD HABITS, LARCH SAWELY, TAMARACK, MICHIGAN, VOLES, SHREWS, 2

85 AUTH GRANGE W.

DATE 1965 .

TITL FIRE AND TREE GROWTH RELATIONSHIPS TO SNOWSHOE RABBITS.

PUBL TALL TIMBERS EIRE ECOL. CONE. 4:111-123.

ANNO SNOWSHOE RABBIT POPULATION EXPLOSIONS OCCUR ONLY ON VERY EARLY SUCCESSIONAL FOREST STAGES, NOT LONG AETER THE OCCURRENCE OE EIRE. ALMOST ALL PLANT SPECIES IMPORTANT TO SNOWSHOE RABBITS HAVE ADAPTATIONS TO FIRE.

KEYS SNOWSHOE HARE, POPULATION DENSITY, CONIEEROUS EOREST, WISCONSIN, MINNESOTA, ALBERTA, BRITISH COLUMBIA, ALASKA, SMALL MAMMALS, POST-EIRE SUCCESSION, WILDEIRE, 2

86 AUTH GULLION G. W.

DATE 1977.

TITL MAINTENANCE OF THE ASPEN ECOSYSTEM AS A PRIMARY WILDLIEE HABITAT.

PUBL PROC. INT. CONGR. GAME BIOL. 13:256-265.

ANNO PROTECTION EROM EIRE AND EROM HARVESTING HAVE CAUSED LOSS OE ASPEN HABITAT THROUGH DECADENCE. SOME SPECIES OF WILDLIEE ARE CLOSELY TIED TO THE ASPEN HABITAT. COMMERCIAL HARVEST CAN BE ADJUSTED ECONOMICALLY TO MEET THE NEEDS OE THESE SPECIES OF WILDLIEE.

KEYS ASPEN, HABITAT, FIRE, BIRDS, PREDATORS, LARGE MAMMALS, 2

87 AUTH GUNDERSON H. L.

DATE 1959.

TITL RED-BACKED VOLE HABITAT STUDIES IN CENTRAL MINNESOTA.

PUBL J. MAMMAL. $40(3): 405-412$.

ANNO AVAILABILITY OE EREE WATER AND THE PRESENCE OE STUMPS, ROTTING LOGS AND ROOT SYSTEMS IN LOOSE FOREST LITTER AND SPAGNUM ARE IMPORTANT EACTORS IN THE HABITAT OF RED-BACKED VOLES.

KEYS SMALL MAMMALS, RED-BACKED VOLES, MINNESOTA, HABITAT, WHITE CEDAR, 3

88 AUTH HALVORSON C. H.

DATE 1981.

TITL SMALL MAMMAL POPULATIONS.

PUBL IN CLEARCUTTING AND FIRE IN THE LARCH-EIR FORESTS OF WESTERN MONTANA - - A MULTIEACETED RESEARCH SUMMARY. N. V. DEBYLE. USDA EOR. SERV. GEN. TECH. REP. INT-99. INTERMT. FOR. AND RANGE EXP. STN., OGDEN, UTAH.

ANNO AETER CLEARCUTTING AND BURNING: DEER MICE INCREASED, RED-BACKED VOLES DISAPPEARED, CHIPMUNKS WERE REDUCED, AND LONG-TAILED VOLES WERE CAUGHT EOR THE FIRST TIME.

KEYS SMALL MAMMALS, DEER MOUSE, RED-TAILED CHIPMUNK, RED-BACKED VOLES, VAGRANT SHREW, FOOD HABITS, VEGETATION STRUCTURE, POST-EIRE SUCCESSION, LARCH-EIR, MONTANA, CLEARCUT, POPULATION 
DENSITY, REPRODUCTION, BROADCAST EIRE, 1

89 AUTH HAMILTON W. J. JR.

DATE 1930.

TITL FOOD OF THE SORICIDAE.

PUBL J. MAMMAL. $11: 26-39$.

ANNO INSECTS MAKE UP MORE THAN HALF THE DIET OF THE SHREWS EXAMINED.

KEYS SMALL MAMMALS, INSECTS, FOOD HABITS, SHREWS, MICE, BIRDS, 2, LOGGING

90 AUTH HAMILTON W. J. JR., COOK D. B.

DATE 1940.

TITL SMALL MAMMALS AND THE FOREST.

PUBL J. FOR. 38(6):468-473.

ANNO SMALL MAMMALS BENEFIT THE FOREST BY CONSUMING LARGE OUANTITIES OF INJURIOUS INSECTS, IMPROVING SOIL AERATION, AND PROVIDING EOOD EOR PREDATORY BIRDS AND MAMMALS. SUGGESTS MANAGEMENT PRACTICES TO INCREASE SMALL MAMMAL POPULATIONS.

KEYS SMALL MAMMALS, FOOD HABITS, INSECTS, HABITAT, SOIL AERATION, 1

91 AUTH HANDLEY C. O. JR.

DATE 1969.

TITL FIRE AND MAMMALS.

PUBL TALL TIMBERS FIRE ECOL. CONE. 9:151-159.

ANNO DISCUSSION OF ADAPTATIONS OE MAMMALS TO FIRE. EMPHASIS ON GRASSLAND HABITATS.

KEYS PIKA, SMALL MAMMALS, LARGE MAMMALS, GRASSLAND, BEHAVIORAL ADAPTATIONS, MORPHOLOGICAL ADAPTATIONS, WILDFIRE, 2

92 AUTH HANSEN L. P., WARNOCK J. E.

DATE 1978.

TITL RESPONSE OF TWO SPECIES OF PEROMYSCUS TO VEGETATIONAL SUCCESSION OE LAND STRIP-MINED FOR COAL.

PUBL AM. MIDL. NAT. $100(2): 416-423$.

KEYS SMALL MAMMALS, DEER MOUSE, WHITE-FOOTED MOUSE, PLANT SUCCESSION, STRIP-MINING, 2

93 AUTH HANSON E. E.

DATE 1977.

TITL RADIOTELEMETRY STUDIES OF ARCTIC FOXES IN PRUDHOE BAy, ALASKA.

PUBL ECOLOGY SECTION H-8 UNIV. OF CALIE. LOS ALAMOS SCIENTIFIC LAB. LOS ALAMOS, NEW MEXICO 87544.

ANNO REPORT ON THE ECOLOGY OF ARCTIC FOX IN PRUDHOE BAY. SOME INEORMATION ON THE EFFECT OE LEMMING POPULATIONS ON THE REPRODUCTION OF FOXES.

KEYS ARCTIC FOX, BIRDS, PREDATION, POPULATION DENSITY, ALASKA, SMALL MAMMALS, 3, PREDATORS

94 AUTH HANSON E. E.

DATE 1978.

TITL THE IMPACT OF A PRESCRIBED BURN IN A TEMPERATE SUBALPINE FOREST UPON THE BREEDING BIRD AND SMALL MAMMAL POPULATIONS.

PUBL M.S. THESIS. CENTRAL WASHINGTON UNIV., ELLENSBURG, WA. 55P.

ANNO POPULATION DENSITIES OF SMALL MAMMALS DECLINED FOLLOWING BURNING EXCEPT FOR THE YELLOW PINE CHIPMUNK. THE DECLINE OF THE OTHER SPECIES WAS ATTRIBUTED TO THE LACK OF GROUND VEGETATION THE FIRST SUMMER FOLLOWING THE BURN. THE NUMBER OF BIRDS REMAINED THE SAME AFTER BURNING BUT THE SPECIES DIVERSITY INCREASED. 
KEYS BIRDS, YELLOW-PINE CHIPMUNK, TOWNSEND'S CHIPMUNK, DOUGLAS' SQUIRREL, RED-BACKED VOLES, DEER MOUSE, SPECIES DIVERSITY, POPULATION DENSITY, HABITAT, MOSAIC, SMALL MAMMALS, PRESCRIBED FIRE, SUBALPINE FOREST, WASHINGTON, 2

95 AUTH HARRIS A. S.

DATE 1968.

TITL SMALL MAMMALS AND NATURAL REFORESTATION IN SOUTHEAST ALASKA. PUBL USDA FOR. SERV. RES. NOTE PNW-75, 7P. PAC. NORTHWEST FOR. AND RANGE EXP. STN., PORTLAND, ORE.

ANNO CONTRARY TO THE USUAL SMALL MAMMAL POPULATION RESPONSES TO LOGGING, IN THIS STUDY PEROMYSCUS WERE SIX TIMES MORE PLENTIEUL IN THE TIMBER THAN IN THE CUTOVER PLOTS, WHEREAS MICROTUS WERE SIX TIMES, AND SOREX TWICE AS NUMEROUS ON THE CUT. DESPITE SMALL MAMMALS, ADEQUATE NATURAL REGENERATION OF SITKA SPRUCE AND WESTERN HEMLOCK OCCURRED.

KEYS SMALL MAMMALS, ALASKA, DEER MOUSE, VOLES, SHREWS, LOGGING, SITKA SPRUCE, WESTERN HEMLOCK, 2

96 AUTH HARTESVELDT R. J., HARVEY H. T.

DATE 1967.

TITL THE EIRE ECOLOGY OE SEQUOIA REGENERATION.

PUBL TALL TIMBERS FIRE ECOL. CONE. 7:65-77.

ANNO CHICKAREES HARVEST AND EAT THE FLESH OF THE SEOUOIA CONE SCALES. THE SEEDS ARE ONLY PARTIALLY CONSUMED. AETER FIRES WHICH KILL MANY FIRS AND PINES, CHICKAREES RELY MORE ON SEOUOIA CONES AND POSSIBLY INCREASE THE DISPERSAL OF SEEDS AT A TIME WHEN SUBSTRATE CONDITIONS RESULTING FROM FIRE ARE OPTIMAL FOR REGENERATION .

KEYS DOUGLAS' SOUIRREL, SEQUOIA, FOOD HABITS, SMALL MAMMALS, WILDEIRE, 3

97 AUTH HARTESVELDT R. J., HARVEY H. T., SHELLHAMMER H. S., STECKER R. E.

DATE 1975.

TITL THE GIANT SEQUOIA OF THE SIERRA NEVADA.

PUBL USDI NATIONAL PARK SERVICE, WASHINGTON D.C. 180 .

ANNO DESCRIBES THE EEFECT OF THE CHICKAREE ON THE DISPERSAL OF SEQUOIA SEED.

KEYS SMALL MAMMALS, DOUGLAS' SQUIRREL, SEQUOIA, FOOD HABITS, 3

98 AUTH HAWLEY V. D., NEWBY E. E.

DATE 1957.

TITL MARTEN HOME RANGE AND POPULATION FLUCTUATIONS.

PUBL J. MAMMAL . 38(2): 174-184.

ANNO HOME RANGES FOR 6 MALE MARTEN AVERAGED .92 SQ. MILES, AND . 27 SQ. MILES FOR 5 EEMALES. POPULATION FLUCTUATIONS OF MARTEN RESPONDED TO THE NUMBERS OF SMALL MAMMALS.

KEYS MARTEN, POPULATION DENSITY, GLACIER NATIONAL PARK, PREDATORS, SMALL MAMMALS, 3, MONTANA

99 AUTH HAYWARD C. L.

DATE 1940.

TITL FEEDING HABITS OF THE RED SQUIRREL.

PUBL J. MAMMAL. $21(2): 220$.

ANNO RECORDS OF RED SOUIRREL CONE CUTTING ACTIVITY AND NUMBER OE DOUGLAS-EIR SEEDS CONSUMED AT ONE TIME.

KEYS RED SOUIRREL, SMALL MAMMALS, FOOD HABITS, DOUGLAS-FiR, SEED, $\mathrm{UTAH}, 3$ 
100 AUTH HEALEY M. C.

DATE 1967.

TITL AGGRESSION AND SELE-REGULATION OE POPULATION SIZE IN DEER MICE.

PUBL ECOLOGY $48(3): 377-391$.

ANNO CHANGES IN GROWTH AND SURVIVAL OE YOUNG DEER MICE CORRELATED TO CHANGES IN THE AGGRESSIVENESS OE ADULT MICE.

KEYS SMALL MAMMALS, DEER MOUSE, POPULATION DENSITY, BRITISE

COLUMBIA, REPRODUCTION, 3

101 AUTH HICKIE P.

DATE 1957.

TITL THE APPLICATION OF ECOLOGY TO WILDLIEE MANAGEMENT.

PUBL ECOLOGI 38(1):53-56.

ANNO RODENT POPULATIONS INCREASE IN WEEDY SHRUBBY HABITAT AETER

LOGGING. AERIAL SEEDING OE DOUGLAS-EIR REOUIRES RODENT CONTROL

EOR SUCCESS. DESCRIBES METHODS OE POSSIBLE CONTROI.

KEYS SMALL MAMMALS, RODENTS, EOOD HABITS, SEED, DOUGLAS-EIR,

POPULATION DENSITY, PACIEIC NORTHWEST, LOGGING, PLANT

SUCCESSION, GRAZING, 2

102 AUTH HISAW E. L., GLOYD H. K.

DATE 1926.

TITL THE BULL SNAKE AS A NATURAL ENEMY OE INJURIOUS RODENTS.

PUBL J. MAMMAL. 7(3):200-205.

ANNO DESCRIPTION OE THE BULL SNAKE AS A PREDATOR OE POCKET GOPHER.

DESCRIBES KILLING TECHNIQUE AND BURROWING HABITS OE THE SNAKE AS WELL AS THE POTENTIAL CONSUMPTION OE GOPHERS.

KEYS SIMLL MAMIALS, REPTILES, PREDATION, BULL SNAKE, FOCKET GOPHERS, 3

103 AUTH HOEEMAN G. R.

DATE 1960.

TITL THE SMALL MAMMAL COMPONENTS OE SIX CLIMAX PLANT ASSOCIATIONS IN EASTERN WASHINGTON AND NORTHERN IDEHO.

PUBL ECOLOGY 41(3):571-572.

ANNO AN EXTENSION OE RICKARD'S 1960 PAPER. IDENTIEIES ELEVEN SPECIES OE SMALL MAMMALS EROM 6 CLIMAX PLANT ASSOCIATIONS THAT HAD NOT BEEN STUDIED BY RICKARD. DESCRIBES HABITATS OE DIEEERENT SPECIES.

KEYS SMALL MAMMALS, IDAHO, WASHINGTON, HABITAT, CHIPMUNKS, RED-BACKED VOLES, SHREWS, DEER MOUSE, MEADOW VOLE, 3

104 AUTH HOEEMAN R. S., PATTIE D. L.

DATE 1968.

TITL A GUIDE TO MONTANA MAMMALS: IDENTIEICATION, HABITAT, DISTRIBUTION AND ABUNDANCE.

PUBL UNIVERSITY OE MONTANA PRINTING SERVICES, MISSOULA. $133 \mathrm{P}$.

ANNO IDENTIEICATION KEY, HABITAT DESCRIPTION, AND DISTRIBUTION MAPS EOR MONTANA MAMMALS.

KEYS SMALL MAMMALS, PREDATORS, LARGE MAMMALS, IDENTIEICATION KEY, HABITAT, MONTANA

105 AUTH HOOVEN E. E.

DATE 1958.

TITL THE RELATIONSHIP OE THE WHITE-EOOTED DEER MOUSE TO

REEORESTATION BY DIRECT SEEDING IN THE TILLAMOOK BURN.

PUBL M.S. TEESIS, OREGON STATE UNIV., CORVALLIS. 72 .

ANNO THE WHITE-EOOTED DEER MOUSE EAT'S AND STORES LARGE OUANTITIES OE CONIEER SEEDS, WHICH PRESENTS A PROBLEM TO REEORESTATION. 
SUCCESS OE CONTROL PROGRAM DEPENDS ON KNOWLEDGE OE LIEE HISTORY EOR BEST TIME TO ATTEMPT CONTROL.

KEYS SMALL MAMMALS, DEER MOUSE, SEED, FOOD HABITS, OREGON, 3

106 AUTH HOOVEN E. F.

DATE 1969.

TITL THE INELUENCE OE EOREST SUCCESSION ON POPULATIONS OE SMALL MAMMALS IN WESTERN OREGON.

PUBL IN WILDLIEE AND REEORESTATION IN THE PACIEIC NORTHWEST. P. 30-34. H. C. BLACK, ED. SCHOOL OF FORESTRY, ORE. STATE UNIV., CORVALLIS.

ANNO REVIEW OE EEEECTS OE EIRE, LOGGING AND OTHER DISTURBANCE ON SMALL ANIMALS. IN OREGON STUDY AREAS, SMALL MAMMALS MORE ABUNDANT IN RECENTLY LOGGED AREA THAN IN MATURE DOUGLAS-EIR. SUCCESSION OE SMALL MAMMAL AND BIRD SPECIES RELATED TO PLANT SUCCESSION AETER LOGGING AND EIRE.

KEYS SMALL MAMMALS, LOGGING, WILDEIRE, OREGON, DOUGLAS-EIR, BIRDS, DEER MOUSE, POST-EIRE SUCCESSION, POPULATION DENSITY, SPECIES COMPOSITION, HABITAT, FOOD HABITS, REPRODUCTION, PRESCRIBED EIRE, 1

107 AUTH HOOVEN E. F.

DATE 1971.

TITL POCKET GOPHER DAMAGE ON PONDEROSA PINE PLANTATIONS IN SOUTHWESTERN OREGON.

PUBL J. WILDL. MANAGE. 35(2):346-353.

ANNO PONDEROSA SEEDLING SURVIVAL WAS REDUCED TO $12 \%$ IN AREAS OCCUPIED BY POCKET GOPHERS. CONTROL OF POCKET GOPHERS IS GENERALLY UNSUCCESSEUL. SUGGESTS CONTROLLING GOPHER POPULATIONS BY MODIEYING THE HABITAT I.E. CHANGING THE VEGETATION OR OTHER IMPORTANT PHYSICAL REQUIREMENTS.

KEYS SMALL MAMMALS, POCKET GOPHERS, PONDEROSA PINE, OREGON, SEED, FOOD HABITS, LOGGING, POPULATION DENSITY, 1, DAMAGE

108 AUTH HOOVEN E. E.

DATE 1973.

TITL EFEECTS OE VEGETATIONAL CHANGES ON SMALL EOREST MAMMALS.

PUBL IN EVEN-AGE MANAGEMENT SYMPOSIUM P.75-97, R. K. HERMANN AND D. P. LAVENDER, EDS., OREGON STATE UNIV, CORVALLIS. 249 P.

ANNO LITERATURE REVIEW OE THE EEEECTS OE VEGETATIONAL CHANGES ON SMALL MAMMALS. CONCLUDES THAT REGARDLESS OF FOREST TREATMENT, THE SMALL MAMMAL BIOMASS REMAINS COMPARABLE TO THAT IN THE UNCUT FOREST AND EXERTS THE SAME PRESSURE ON REGENERATION.

KEYS SMALL MAMMALS, CLEARCUT, FIRE, LOGGING, POST-EIRE SUCCESSION, SEED, FOOD HABITS, SPECIES COMPOSITION, POPULATION DENSITY, 2

109 AUTH HOOVEN E. E.

DATE 1973.

TITL RESPONSE OE THE OREGON CREEPING VOLE TO THE CLEARCUTTING OF A DOUGLAS EIR EOREST.

PUBL NORTHWEST SCI. 47(4):256-264.

ANNO THREE YEAR STUDY OE EEEECT OF CLEARCUTTING AND BURNING ON CREEPING VOLE. VOLES INCREASED RAPIDLY WHEN TIMBER WAS REMOVED. INCREASED HERBACEOUS GROWTH AND RELEASED NUTRIENTS MAY IMPROVE HABITAT EOR VOLES.

KEYS CREEPING VOLE, SMALL MAMMALS, DOUGLAS-EIR, OREGON, CLEARCUT, HABITAT, POST-EIRE SUCCESSION, REPRODUCTION, POPULATION DENSITY, SLASH EIRE, 2 
110 AUTH HOOVEN E. E.

DATE 1973.

TItL A WILDLIEE BRIEE EOR THE CLEARCUT LOGgING OE DOUGLAS-EIR.

PUBL J. EOR. $71(4): 210-214$.

ANNO STAGGERED CLEARCUT LOGGING OE 30 TO 60 ACRES IS BENEEICIAL TO WILDLIEE IN NORTHWESTERN OREGON. SMALL MAMMAL POPULATIONS INCREASE AS THE VEGETATION INCREASES AND ASSOCIATED ANTHROPOD POPULATIONS INCREASE. DESCRIBES SUCCESSIONAL STAGES PREEERRED BY DIEEERENT SMALL MAMMALS.

KEYS CLEARCUT, DOUGLAS-EIR, LARGE MAMMALS, SMALL MAMMALS, EISH, SOIL CHARACTERISTICS, OREGON, REPTILES, BIRDS, PLANT SUCCESSION, 1

11 AUTH HOOVEN E. E.

DATE 1975.

TITL BAITING TO REDUCE LOSSES OF CONIEER SEEDS TO SMALL EOREST MAMMALS.

PUBL RES. NOTE NO. 55. SCHOOL OE EOR., ORE. STATE UNIV. AND EOR. RES. LAB., CORVALLIS.

ANNO A CAGED DEER MOUSE CAN EAT 250-350 DOUGLAS-EIR SEEDS PER DAY. DESCRIBES THE EEEECTIVENESS OE DIEEERENT RODENTICIDES TO CONTROL SMALL MAMMALS WHICH EAT CONIEER SEEDS.

KEYS SMALL MAMMALS, EOOD HABITS, POISONS, PORULATION DENSITY, OREGON

112 AUTH HOOVEN E. F., BLACK H. C., LOWRIE J. C.

DATE 1979.

TITL DISTURBANCE OF SMALL MAMMAL LIVE TRAPS BY SPOTTED SKUNKS.

PUBL NORTHWEST SCI. 53(2):79-81.

ANNO SKUNKS WERE CONSIDERED RESPONSIBLE EOR DISTURBING SMALL MAMMAL TRAPS AND EATING TRAPPED MICE.

KEYS SMALL MAMMALS, SKUNK, PREDATORS, SLASH EIRE, TRAPPING, OREGON, LOGGING, DEER MOUSE, SHREWS, TOWNSEND'S CHIPMUNK, CREEPING VOLE, 2

113 AUTH HORN E. E.

DATE 1938.

TITL SOME WILDLIEE-EOREST RELATIONSHIPS.

PUBL TRANS. N. AM. WILDL. CONE. 3:376-380.

ANNO DISCUSSES THE EEEECTS OE EIRE AND LOGGING ON WILDLIEE IN TERMS OE COVER, EOOD, AND PREDATION.

KEYS SMALL MAMMALS, EOOD HABITS, VEGETATION STRUCTURE, LARGE MAMMALS, LOGGING, PREDATION, HABITAT, MORTALITY, PRESCRIBED EIRE, 2

114 AUTH HORTON J.

DATE 1930.

TITL BIRDS AND ANIMALS KILLED BY EOREST EIRES.

PUBL MURRELET $11(2): 22$.

KEYS MAMMALS, BIRDS, WILDEIRE, MORTALITY, 2

115 AUTH HOUTCOOPER W. C.

DATE 1978.

TITL EOOD HABITS OF RODENTS IN A CULTIVATED ECOSYSTEM.

PUBL J. MAMMAL. 59(2):427-430.

ANNO RODENTS UTILIZED PLANT MATERIAL EOR EOOD IN WINTER, ANIMAL MATERIAL (INSECTS) UTILIZED IN SUMMER.

KEYS SMALL MAMMALS, HOUSE MOUSE, DEER MOUSE, EOOD HABITS, INDIANA, CORN , 3 
116 AUTH HOWARD W. E., EENNER R. L., CHILDS H. E. JR.

DATE 1959.

TITL WILDLIEE SURVIVAL ON BRUSH BURNS.

PUBL J. RANGE MANAGE. 12:230-234.

ANNO MOST VERTEBRATES ARE NOT KILLED BY EIRE. CHANGES IN POPULATION DENSITIES AETER EIRE ARE IN RESPONSE TO ALTERATIONS OF HABITAT. DATA TAKEN EROM ANIMALS IN CAGES WITH TEMPERATURE RECORDING DEVICES AND OBSERVATIONS OE WILD ANIMALS BEFORE, DURING AND AETER THE FIRE.

KEYS SMALL MAMMALS, REPTILES, MORTALITY, BRUSH-GRASS, CALIFORNIA, BIRDS, PRESCRIBED FIRE, 1

117 AUTH INGRAM R.

DATE 1973.

TITL WOLVERINE, EISHER, AND MARTEN IN CENTRAL OREGON.

PUBL

ANNO

OREGON STATE GAME COMM. CENTRAL REGION ADM. REP. 73-2. 39P.

LOGGING AND FIRE HAVE A NEGATIVE EEFECT ON FISHER AND MARTEN POPULATIONS. WOLVERINE HAVE BEEN LESS EEFECTED BECAUSE OF THE REMOTENESS OF THEIR HABITAT. HUMAN ACTIVITY WILL LIMIT WOLVERINE POPULATIONS. DISCUSSION OF HABITAT, FOOD HABITS AND REPRODUCTION.

KEYS WOLVERINE, EISHER, MARTEN, OREGON, PREDATORS, PREDATION, SMALL MAMMALS, HABITAT, LOGGING, FIRE, CONIFEROUS FOREST, POPULATION DENSITY, 3

118 AUTH JAMESON E. W. JR.

DATE 1955.

TITL

PUBL

ANNO

SOME EACTORS AEEECTING ELUCTUATIONS OF MICROTUS AND PEROMYSCUS. J. MAMMAL . 36(2):206-209.

DISCUSSES THE DIFEERENCES IN POPULATION FLUCTUATIONS OF PEROMYSCUS AND MICROTUS AND THEIR RELATIONSHIP TO FACTORS SUCH AS FOOD QUALITY, FOOD OUANTITY, HABITAT, AND STRESS.

KEYS SMALL MAMMALS, VOLES, DEER MOUSE, POPULATION DENSITY, FOOD HABITS , 2

119 AUTH JOHNSON D. R., HANSEN R. M.

DATE 1969.

TITL EFEECTS OF RANGE TREATMENT WITH 2,4-D ON RODENT POPULATIONS.

PUBL J. WILDL. MANAGE. 33(1):125-132.

ANNO TREATMENT WITH 2,4-D RESULTED IN AN INCREASE IN GRASS COVER AND A DECREASE IN FORBS AND BRUSH. DISCUSSES EEFECT ON POPULATION DENSITY AND LITTER SIZE OF VARIOUS RODENTS. 2, 4-D CAUSED A REDUCTION OF GOPHERS AND CHIPMUNKS, WHILE VOLES INCREASED. GOPHERS RESPONDED PRIMARILY TO CHANGES IN EOOD, CHIPMUNKS TO FOOD AND COVER, AND VOLES TO COVER.

KEYS SMALL MAMMALS, POPULATION DENSITY, HERBICIDE, COLORADO, BRUSH-GRASS, DEER MOUSE, POCKET GOPHERS, MONTANE VOLE, LEAST CHIPMUNK, FOOD HABITS, VEGETATION STRUCTURE, 1

120 AUTH JOHNSON M.K., HANSEN R. M.

DATE 1979.

TITL COYOTE FOOD HABITS ON THE IDAHO NATIONAL ENGINEERING LABORATORY.

PUBL J. WILDL. MANAGE. 43(4):951-956.

ANNO COYOTES SELECT AN ABUNDANT FOOD AND MAKE IT A STAPLE AND THEREFORE ARE SELECTIVE RATHER THAN OPPORTUNISTIC PREDATORS.

KEYS PREDATORS, COYOTE, FOOD HABITS, IDAHO, SAGEBRUSH, SMALL MAMMALS, PREDATION, RABBITS, 1 
121 AUTH JONES J. H., SMITH N. S.

DATE 1979.

TITL BOBCAT DENSITY AND PREY SELECTION IN CENTRAL ARIZONA.

PUBL J. WILDL. MANAGE. $43(3): 666-672$.

ANNO ANALYSIS OF BOBCAT SCATS FROM THREE BAR WILDLIEE AREA INDICATED THAT RODENTS (67\%), AND LAGOMORPHS (38\%), WERE THE MOST COMMON FOOD ITEMS. POPULATION DENSITIES OE RODENTS AND LAGOMORPHS WERE NOT RELATED TO THE SELECTION OF PREY BY BOBCATS.

KEYS PREDATORS, BOBCAT, PREDATION, ARIZONA, SMALL MAMMALS, DESERT COTTONTAIL, KANGAROO RATS, POCKET MOUSE, WOODRATS, BLACK-TAILED JACK RABBIT, 1

122 AUTH KEITH L. B., SURRENDI P. C.

DATE 1971.

TITL EEFECTS OF EIRE ON A SNOWSHOE HARE POPULATION.

PUBL J. WILDL. MANAGE. 35(1):16-26.

ANNO SNOWSHOE HARES MOVED EROM SEVERELY BURNED SITES TO SURROUNDING HABITAT, RETURNING THE SECOND SUMMER AETER THE FIRE AS BRUSH COVER SPROUTED. THERE WAS NO EVIDENCE OE HARES KILLED BY THE FIRE.

KEYS SMALL MAMMALS, SNOWSHOE HARE, MORTALITY, MIGRATION, POPULATION DENSITY, REPRODUCTION, ALBERTA，WILDEIRE， 2

123 AUTH KEITH L. B., TODD A. W., BRAND C. J., ADAMCIK R. S., RUSH D. H. DATE 1977.

TITL AN ANALYSIS OF PREDATION DURING A CYCLIC FLUCTUATION OF SNOWSHOE HARES.

PUBL PROC. INT. CONGR. GAME BIOL. 13:151-175.

ANNO DESCRIPTION OF LYNX, COYOTE, AND RAPTOR, POPULATION RESPONSES TO FLUCTUATIONS IN HARE AND GROUSE DENSITIES. SUGGESTS THE 10-YEAR CYCLE IS GENERATED INTRINSICALLY BY SUCCESSIVE HARE-VEGETATION AND HARE-PREDATOR CYCLES.

KEYS SMALL MAMMALS, PREDATORS, RAPTORS, SNOWSHOE HARE, LYNX, COYOTE, GREAT HORNED OWL, GOSHAWK, RED-TAILED HAWK, BIRDS, RUEFED GROUSE, POPULATION DENSITY, LYNX, 2

124 AUTH KIPP D. H.

DATE 1941.

TITL WILDLIEE IN A EIRE.

PUBL AM. FOR. 37(6):323-325.

ANNO DESCRIBES DIRECT EFFECTS OF WILDEIRE ON WILDLIFE.

KEYS WILDEIRE, MORTALITY, WISCONSIN, BIRDS, LARGE MAMMALS, SMALL MAMMALS, RABBITS, RAPTORS, FISH, FALL BURN, BIRDS, 2

125 AUTH KIRKLAND G. L. JR.

DATE 1977.

TITL RESPONSES OF SMALL MAMMALS TO THE CLEARCUTTING OF NORTHERN APPALACHIAN FORESTS.

PUBL J. MAMMAL. 58(4):600-609.

ANNO CLEARCUTTING IN BOTH NORTHERN DECIDUOUS AND BOREAL CONIEEROUS FORESTS RESULTED IN INCREASED SMALL MAMMAL ABUNDANCE AND DIVERSTY WHICH PERSISTED UNTIL SUCCESSION RETURNED THE AREA TO FOREST.

KEYS SMALL MAMMALS, CLEARCUT, SPECIES DIVERSITY, POPULATION DENSITY, WEST VIRGINIA, PLANT SUCCESSION, 2 
126 AUTH KIRKPATRICK R. C.

DATE 1941.

TITL EFEECTS OF FIRES ON WILDLIFE.

PUBL WIS. CONSERV. BULL. $6(5): 28-30$.

KEYS SMALL MAMMALS, FIRE

127 AUTH KLEBENOW D. R., BEALL R., BRUNER A., MASON R., ROUNDY B., STAGER W., WARD K.

DATE 1976.

TITL CONTROLLED FIRE AS A MANAGEMENT TOOL IN THE PINYON-JUNIPER WOODLAND, NEVADA

PUBL ANN. PROG. REP. COOP. RES. USDA AND NEV. AGRIC. STN.

ANNO CONTROLLED BURNING INCREASED NUMBERS OF RODENTS AND BIRDS. SPECIES DIVERSITY INCREASED FOR BIRDS, BUT DECREASED FOR RODENTS.

KEYS PRESCRIBED FIRE, SMALL MAMMALS, BIRDS, NEVADA, PINYON-JUNIPER, POPULATION DENSITY, SPECIES DIVERSITY， 3

128 AUTH KOEHLER G. M., HORNOCKER M. G.

DATE 1977.

TITL EIRE EEFECTS ON MARTEN HABITATS.

PUBL J. WILDL. MANAGE. 41(3):500-505.

ANNO DESCRIBES THE EFEECTS OF FIRE ON MARTEN HABITAT AND FOOD SOURCES.

KEYS MARTEN, VOLES, DEER MOUSE, CHIPMUNKS, PREDATION, HABITAT, IDAHO, FOOD HABITS, SMALL MAMMALS, PREDATORS, WILDEIRE, 2

129 AUTH KOEHLER G. M., MOORE W. R., TAYLOR A. R.

DATE 1975.

TITL PRESERVING THE PINE MARTEN MANAGEMENT GUIDELINES FOR WESTERN EORESTS.

PUBL WESTERN WILDLANDS $2(3): 31-36$.

ANNO DESCRIBES MARTEN HABITAT REQUIREMENTS AND EOOD HABITS. GIVES GUIDELINES FOR FOREST MANAGEMENT FOR MARTEN HABITAT.

KEYS MARTEN, HABITAT, FOOD HABITS, PREDATION, SMALL MAMMALS, IDAHO, MOSAIC, WILDFIRE, LOGGING, 3

130 AUTH KOMAREK E. V. SR.

DATE 1963.

TITL FIRE, RESEARCH, AND EDUCATION.

PUBL TALL TIMBERS FIRE ECOL. CONF. 2:181-187.

ANNO COTTON RATS DECREASED AND GOLDEN MICE AND COTTON MICE INCREASED WHEN AN OPEN PINE WOODS WAS PROTECTED FROM FIRE FOR 4 YEARS. NONE OF THE 52 COTTON RATS ON A 4 ACRE BROOM-SEDGE FIELD WERE HARMED WHEN THE FIELD WAS BURNED AND ONLY 6 WERE SEEN ON THE FIRE BREAK. THE REST HAD TAKEN REFUGE IN 'POP HOLES'.

KEYS COTTON RAT, GOLDEN MOUSE, COTTON MOUSE, MORTALITY, POPULATION DENSITY, SOUTHEAST, SMALL MAMMALS, PRESCRIBED FIRE, 2

131 AUTH KOMAREK E. V. SR.

DATE 1965.

TITL FIRE ECOLOGY-GRASSLANDS AND MAN.

PUBL TALL TIMBERS FIRE ECOL. CONE. 4:169-220.

ANNO DESCRIBES DIRECT AND INDIRECT EFEECTS OF FIRE ON PREDATORS AND PREY IN GRASSLAND.

KEYS COTTON RAT, HOUSE MOUSE, OLDFIELD MOUSE, GRAY FOX, RED FOX, SHRIKE, RAPTORS, PREDATION, BEHAVIORAL ADAPTATIONS, GRASSLAND, SMALL MAMMALS, WILDFIRE, 2 
132 AUTH KOMAREK E. V. SR.

DATE 1969.

TITL FIRE AND ANIMAL BEHAVIOR.

PUBL TALL TIMEERS FIRE ECOL. CONE. 9:161-207.

ANNO DESCRIBES BEHAVIORAL ADAPTATIONS OF ANIMALS TO FIRE.

KEYS COTTON RAT, RABBITS, LARGE MAMMALS, REPTILES, AMPHIBIANS, BIRDS, MORTALITY, PREDATION, BEHAVIORAL ADAPTATIONS, SMALL MAMMALS, WILDEIRE, 1

133 AUTH KOMAREK R.

DATE 1963.

TITL FIRE AND THE CHANGING WILDLIEE HABITAT.

PUBL TALL TIMBERS FIRE ECOL. CONE. 5:177-194.

ANNO DISCUSSES THE EFEECTS OF EIRE ON PREY AND PREDATOR POPULATIONS.

KEYS DEER MOUSE, COLUMBIAN GROUND SOUIRREL, MOUNTAIN LION, COYOTE, BEAVER, MARTEN, LARGE MAMMALS, POPULATION DENSITY, PREDATIOŃ, SMALL MAMMALS, WILDEIRE, PRESCRIBED FIRE, 2, PREDATORS

134 AUTH KORSCHGEN L. J.

DATE 1957.

TITL FOOD HABITS--COYOTES, EOXES, HOUSE CATS, BOBCATS--IN MISSOURI. PUBL MISSOURI CONSERV. COMM. P-R REP. 15, 64P.

ANNO STUDY OF THE PRINCIPLE FOODS OF COYOTES, FOXES, HOUSECATS, AND BOBCATS. RABBITS WERE GENERALLY THE MOST IMPORTANT PREY SPECIES.

KEYS PREDATORS, COYOTE, RED FOX, GRAY FOX, BOBCAT, HOUSECAT, SMALL MAMMALS, MISSOURI, BIRDS, 2

135 AUTH KREFTING L. W., AHLGREN C. E.

DATE 1974.

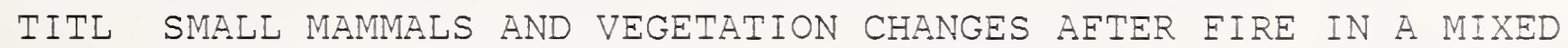
CONIEER HARDWOOD FOREST.

PUBL ECOLOGY 55(6):1391-1398.

ANNO DEER MICE WERE THE MOST ABUNDANT SMALL MAMMALS ON 2 WILDEIRE AREAS IN MINNESOTA FOR THE EIRST 7 YEARS. LATER RED-BACKED VOLES INCREASED APPARENTLY IN RESPONSE TO VEGETATION CHANGES. EOOD AND COVER ARE IMPORTANT INELUENCES ON SMALL MAMMAL POPULATIONS AETER EIRE.

KEYS SMALL MAMMALS, POST-EIRE SUCCESSION, POPULATION DENSITY, DEER MOUSE, RED-BACKED VOLES, MEADOW VOLE, FOOD HABITS, HABITAT, MIXED CONIEER-HARDWOOD, MINNESOTA, WILDEIRE, 1

136 AUTH LAWRENCE G. E.

DATE 1966.

TITL ECOLOGY OF VERTEBRATE ANIMALS IN RELATION TO CHAPARRAL FIRE IN THE SIERRA NEVADA EOOTHILLS.

PUBL ECOLOGY $47(2): 278-291$.

ANNO REPORTS ON FIRE MORTALITY OF SMALL MAMMALS. MORTALITY FROM POST-FIRE PREDATION WAS CONSIDERED MORE SIGNIEICANT THAN FIRE MORTALITY. SPECIES CHANGED EROM BRUSH-DWELLING TO GRASS DWELLING BIRDS AND SMALL MAMMALS.

KEYS SMALL MAMMALS, BIRDS, PREDATORS, RAPTORS, POPULATION DENSITY, SPECIES DIVERSITY, MORTALITY, CHAPARRAL, CALIFORNIA, HABITAT, PRESCRIBED FIRE, RELATIVE HUMIDITY, I

137 AUTH LAWRENCE W. H.

DATE 1954.

TITL MICHIGAN BEAVER POPULATIONS AS INELUENCED BY FIRE AND LOGGING. PUBL PH.D. DISSERTATION, UNIV. MICH., ANN ARBOR. $219 P$. 
ANNO BEAVER WERE STUDIED AS A COMPONENT OF THE FOREST COMMUNITY. EIRE, WINTHROW, AND LUMBERING HAVE MAJOR ROLES IN THE DISTRIBUTION AND ABUNDANCE OF BEAVER BY PROVIDING EAVORABLE HABITAT. SUGGESTS INTEGRATING BEAVER MANAGEMENT INTO THE EOREST MANAGEMENT PROGRAM AS A PART OE THE NATURALLY OCCURRING ASPEN-CONIEER SUCCESSIONAL CYCLE.

KEYS SMALL MAMMALS, BEAVER, LOGGING, FIRE, MICHIGAN, ASPEN, PLANT SUCCESSION, 1

138 AUTH LENSINK C. J., SKOOG R. O., BUCKLEY J. L.

DATE 1955.

TITL FOOD HABITS OE MARTEN IN INTERIOR ALASKA AND THEIR SIGNIEICANCE.

PUBL J. WILDL. MANAGE. 19(3):364-368.

ANNO MARTEN SHOW GREAT ELEXIBILITY IN THEIR DIET. FOOD PLAYS A VERY IMPORTANT ROLE IN THE BEHAVIOR, MOVEMENTS AND SELECTION OE HABITAT BY MARTEN.

KEYS MARTEN, FOOD HABITS, PREDATION, ALASKA, PREDATORS, 2

139 AUTH LOBUE J., DARNELL R. M.

DATE 1959.

TITL EEEECT OF HABITAT DISTURBANCE ON A SMALL MAMMAL POPULATION.

PUBL J. MAMMAL . 40:425-437.

ANNO PRAIRIE DEER MICE SHOWED A POSITIVE RESPONSE TO REDUCED VEGETATION AFTER MOWING, WHILE MICROTUS PREEERRED COVER. FOLLOWING MOWING THERE WAS A CHANGE IN SEX RATIO AND IN THE INELUX OE NEW INDIVIDUALS IN THE DISTURBED AREA.

KEyS SMALL MAMMALS, MEADOW VOLE, DEER MOUSE, MOWING, HABITAT, ALFALEA, MIGRATION, VEGETATION STRUCTURE, 2

140 AUTH LONG C. A., KEREOOT W. C.

DATE 1963.

TITL MAMMALIAN REMAINS EROM OWL-PELLETS IN EASTERN WYOMING.

PUBL J. MAMMAL . 44(1):129-131.

ANNO LIST OF SMALL MAMMALS FOUND IN OWL PELLETS.

KEYS BIRDS, SMALL MAMMALS, OWLS, PREDATION, WYOMING, 3

141 AUTH LOWE P. O.

DATE 1975.

TITL POTENTIAL WILDLIEE BENEEITS OE FIRE IN PONDEROSA PINE FORESTS.

PUBL M.S. THESIS. UNIV. ARIZONA, TUCSON.

ANNO OUANTIEICATION OF WILDLIEE BENEFITS FROM WILDEIRE IN TERMS OF

TIME TREND RESPONSE CURVES CONVERTED TO ANNUITIES OR ANNUALIZED RETURN EROM THE RESOURCE. BENEEITS WERE EXPECTED FOR SOME RODENTS BUT LOSSES COULD BE EXPECTED FOR COTTONTAIL AND CHIPMUNKS .

KEYS WILDEIRE, SMALL MAMMALS, LARGE MAMMALS, BIRDS, ARIZONA, HABITAT, COTTONTAIL RABBIT, CHIPMUNKS, RODENTS, PONDEROSA PINE, 2

142 AUTH LOWE P. O., FEOLLIOTT P. F., DIETERICH J. H., PATTON D. R. DATE 1978.

TITL DETERMINING POTENTIAL WILDLIEE BENEEITS FROM WILDEIRE IN ARIZONA PONDEROSA PINE FORESTS.

PUBL USDA FOR. SERV. GEN. TECH. REP. RM-52, 12P. ROCKY MT. EOR. AND RANGE EXP. STN., EORT COLLINS, CO.

ANNO WILDLIEE USE OF BURNED AREAS WAS EVALUATED AND CONVERTED TO DOLLAR VALUES OF BENEFITS TO WILDLIEE. WILDLIFE USE OF AREAS 1 , 3, 7, AND 20 YEARS AETER EIRE WAS STUDIED. 
KEYS RODENTS, WHITE-TAILED DEER, ELK, BIRDS, POST-EIRE SUCCESSION, EOOD HABITS, HABITAT, PONDEROSA PINE, ARIZONA, POPULATION DENSITY, SMALL MAMMALS, LARGE MAMMALS, WILDEIRE, 3

143 AUTH LUBINA J. A.

DATE 1978.

TITL THE EEFECTS OF EIRE ON RODENT POPULATIONS IN THE CHAPARRAL OE SOUTHERN CALIEORNIA: A COMPARATIVE APPROACH.

PUBL M.A. THESIS. CALIE. STATE UNIV., LONG BEACH. 98P.

ANNO FIRE CAUSED A REDUCTION IN SHRUB COVER AND AN INCREASE IN HERBACEOUS VEGETATION. AS A RESULT, THE AGILE KANGAROO RAT INCREASED IN NUMBERS, THE DUSKY-EOOTED WOODRAT DECREASED, DEER MICE AND CALIFORNIA VOLES COLONIZED THE BURNED SITE AND BRUSH MICE DISAPPEARED. POCKET MICE AND CALIFORNIA VOLE DENSITIES WERE LEAST AEEECTED BY THE FIRE. THE INDIRECT IMPACT OE CHANGE IN VEGETATION STRUCTURE WAS THE MOST IMPORTANT IMPACT OE THE FIRE.

KEYS SMALL MAMMALS, FIRE, CHAPARRAL, CALIFORNIA, SPECIES COMPOSITION, POPULATION DENSITY, VEGETATION STRUCTURE, 1, KANGAROO RATS, DUSKY-FOOTED WOODRAT, DEER MOUSE, CALIEORNIA VOLE, BRUSH MOUSE

144 AUTH LUTZ H. J.

DATE 1956.

TITL THE ECOLOGICAL EEFECTS OF EOREST FIRES IN THE INTERIOR OF ALASKA.

PUBL U.S. DEP. AGRIC. TECH. BULL. 1133. 121P.

ANNO FIRE CAUSES THE DISAPPEARANCE OF MARTEN. SMALL MAMMALS WHICH ARE EOOD FOR PREDATORS ARE KILLED WHEN THEIR HABITAT BURNS.

KEYS MARTEN, ALASKA, SMALL MAMMALS, PREDATORS, WILDEIRE, BIRDS, FISHER， LYNX， ERMINE， LARGE MAMMALS, HABITAT, 3

145 AUTH LYON L. J., CRAWEORD H. S., CZUHAI E., EREDRIKSEN R.L., HARLOW R. E., METZ L. J., PEARSON H. A.

DATE 1978.

TITL EEEECTS OE EIRE ON FAUNA A STATE OF THE ART REVIEW.

PUBL USDA EOR. SERV. GEN. TECH. REP. WO-6, 4IP.

ANNO REVIEW OF THE LITERATURE ON THE EFEECTS OF EIRE ON ANIMALS, INCLUDING INVERTEBRATES.

KEYS FIRE, SMALL MAMMALS, LARGE MAMMALS, BIRDS, HABITAT, VEGETATION STRUCTURE， MORTALITY，BIBLIOGRAPHY， I

146 AUTH MANVILLE R. H.

DATE 1959.

TITL THE COLUMBIAN GROUND SOUIRREL IN NORTHWESTERN MONTANA.

PUBL J. MAMMAL. $40(1): 26-45$.

ANNO A LIEE HISTORY OF COLUMBIAN GROUND SOUIRRELS IN GLACIER NATIONAL PARK.

KEYS SMALL MAMMALS, COLUMBIAN GROUND SQUIRREL, MONTANA, 2

147 AUTH MARSHALL J. T. JR.

DATE 1942 .

TITL EOOD AND HABITAT OF THE SPOTTED OWL.

PUBL CONDOR 44(2):66-67.

ANNO SPOTTED OWL PREYS ON SMALL MAMMALS, BIRDS, AND CRICKETS. HABITAT RATHER THAN FOOD SEEM TO LIMIT DISTRIBUTION.

KEYS RAPTORS, PREDATION, SMALL MAMMALS, SPOTTED OWL, TRANSITION ZONE EOREST, OREGON, BIRDS, 3 
148 AUTH MARSHALL W. H.

DATE 1942 .

TITL THE BIOLOGY AND MANAGEMENT OF THE PINE MARTEN IN IDAHO.

PUBL PH.D. DISSERTATION, UNIV. MICH., ANN ARBOR. 107P.

ANNO DESCRIBES BIOLOGY, HABITAT, MOVEMENTS, AND EOOD OF THE PINE MARTEN. PRIMARY FOOD ITEMS WERE FLYING SQUIRREL, RED SOUIRREL, SNOWSHOE HARE, RED-BACKED VOLE, BIG GAME CARCASSES, SHREWS, AND BERRIES. FIR AND SPRUCE FIR HABITAT WERE USED THE MOST, BUT CONCLUDES THAT FOOD SUPPLY MAY BE MORE IMPORTANT THAN COVER TYPE. LOGGING ON SMALL SCALE WAS NOT DETRIMENTAL. SINCE FIRE CONTROL WAS GOOD, CATESTROPHIC FIRE WAS NOT EXPECTED TO ELIMINATE HABIT. MAKES MANAGEMENT SUGGESTIONS ESPECIALLY PERTAINING TO TRAPPING.

KEYS MARTEN, SMALL MAMMALS, PREDATORS, IDAHO, SPRUCE-FIR, HABITAT, EOOD HABITS, 2

149 AUTH MARSHALL W. H.

DATE 1946.

TITL WINTER EOOD HABITS OE THE PINE MARTEN IN MONTANA.

PUBL J. MAMMAL. 27:83-84.

ANNO RED SOUIRRELS, RED-BACKED VOLES AND SNOWSHOE HARE WERE MOST IMPORTANT FOOD ITEMS FOR MARTEN IN MONTANA.

KEYS PREDATORS, MARTEN, FOOD HABITS, MONTANA, RED SQUIRREL, RED-BACKED VOLES, SNOWSHOE HARE, SMALL MAMMALS, 2

150 AUTH MARSHALL $W$. H.

DATE 1951.

TITL PINE MARTEN AS A FOREST PRODUCT.

PUBL J. EOR. 49(2):899-905.

ANNO DISCUSSES MARTEN ECOLOGY- FOOD, HABITAT, REPRODUCTION. MAKES SUGGESTIONS FOR MANAGING MARTEN AS A FOREST PRODUCT FOR TRAPPERS. MENTIONS EFEECTS OF LOGGING AND FIRE SUPPRESSION ON MARTEN.

KEYS MARTEN, PREDATORS, IDAHO, MONTANA, HABITAT, FOOD HABITS, SMALL MAMMALS, BIRDS, POPULATION DENSITY, FIRE SUPPRESSION, 2, LOGGING

151 AUTH MARSTON R. B., JULANDER O.

DATE 1961.

TITL PLANT COVER REDUCTIONS BY POCKET GOPHERS FOLLOWING EXPERIMENTAL REMOVAL OE ASPEN EROM A WATERSHED AREA IN UTAH.

PUBL J. EOR. 59(2):100-102.

ANNO POCKET GOPHERS REDUCED PLANT COVER ON EXPERIMENTAL PLOT WHERE ASPEN HAD BEEN REMOVED TO THE EXTENT THAT THERE WAS CONCERN ABOUT POTENTIAL EROSION.

KEYS SMALL MAMMALS, POCKET GOPHERS, LOGGING, ASPEN, UTAH, FOOD HABITS, POPULATION DENSITY, 2

152 AUTH MARTELL A. M.

DATE 1978

TITL SELECTION OE CONIFER SEEDS BY DEER MICE AND RED-BACKED VOLES. PUBL CAN. J. FOR. 9(2):201-204.

ANNO IN LABORATORY EXPERIMENTS, BOTH DEER MICE AND RED-BACKED VOLES STRONGLY PREEERRED THE SEEDS OE WHITE PINE OVER THOSE OF JACKPINE OR BLACK SPRUCE.

KEYS SMALL MAMMALS, DEER MOUSE, RED-BACKED VOLES, SEED, WHITE PINE, JACK PINE, BLACK SPRUCE, 3 
153 AUTH MASER C., GASHWILER J. S.

DATE 1978.

TITL INTERRELATIONSHIPS OF WILDLIEE AND WESTERN JUNIPER.

PUBL IN PROCEEDINGS OF THE WESTERN JUNIPER ECOLOGY AND MANAGEMENT WORKSHOP. BEND, ORE. USDA FOR. SERV. GEN. TECH. REP. PNW-74, P. 37-82, 1978. PAC. NORTHWEST AND RANGE EXP. STN., PORTLAND, ORE.

ANNO DESCRIBES WILDLIEE HABITAT (NESTING, EEEDING AND COVER) PROVIDED BY WESTERN JUNIPER, FOR 83 SPECIES OF BIRDS AND 23 SPECIES OF MAMMALS.

KEYS BIRDS, WESTERN JUNIPER, HABITAT, LARGE MAMMALS, SMALL MAMMALS, PREDATORS, 3

154 AUTH MASER C., TRAPPE J. M., NUSSBAUM R. A.

DATE 1978.

TITL FUNGAL-SMALL MAMMAL INTERRELATIONSHIPS WITH EMPHASIS ON OREGON CONIFEROUS FORESTS.

PUBL ECOLOGY 59(4):799-809.

ANNO ALTHOUGH SMALL MAMMALS MAY IMPEDE REFORESTATION THEY ARE ALSO IMPORTANT FOR REFORESTATION AS VECTORS FOR MYCORRHIZAL DISPERSAL .

KEYS SMALL MAMMALS, FOOD HABITS, MYCORRHIZAL FUNGI, OREGON

155 AUTH MASER C., TRAPPE J. M., URE D. C.

DATE 1978.

TITL IMPLICATIONS OF SMALL MAMMAL MYCOPHAGY TO THE MANAGEMENT OF WESTERN FORESTS.

PUBL TRANS. NORTH AM. WILDL. NAT. RESOUR. CONE. 43:78-88.

ANNO THERE IS A COMPLEX INTERRELATIONSHIP BETWEEN TREES, MYCORRHIZAL EUNGI, AND SMALL MAMMALS. IN MANAGING FORESTS ALL OF THESE INTERACTIONS NEED TO BE CONSIDERED.

KEYS SMALL MAMMALS, FOOD HABITS, MYCORRHIZAL FUNGI, CONIFEROUS EOREST

156 AUTH MCGEE J. M.

DATE IN PRESS.

TITL SMALL MAMMAL RESPONSES TO PRESCRIBED BURNING OE BIG SAGE BRUSH. PUBL J. RANGE MANAGE.

KEYS SMALL MAMMALS, SAGEBRUSH, PRESCRIBED FIRE, WYOMING, SPRING BURN, FALL BURN, 2, GRAND TETON NATIONAL PARK, POSTEIRE SUCCESSION, MOSAIC, SPECIES COMPOSITION, MASKED SHREW, VAGRANT SHREW, LEAST CHIPMUNK, DEER MOUSE, MEADOW VOLE, MONTANA VOLE, WESTERN JUMPING MOUSE, LONG-TAILED WEASEL, PREDATORS

157 AUTH MCGEE J. M.

DATE 1976.

TITL SOME EEEECTS OF FIRE SUPPRESSION AND PRESCRIBED BURNING ON BIRDS AND SMALL MAMMALS IN SAGEBRUSH.

PUBL PH.D. DISSERTATION. UNIV. WYOMING, LARAMIE. $134 \mathrm{P}$.

ANNO CHANGES IN BIRD DENSITY AND DIVERSITY AFTER BURNING SAGEBRUSH LASTED ONLY 2-3 YEARS. TOTAL SMALL MAMMAL NUMBERS WERE NOT DEPLETED BY FIRE, BUT EACH SPECIES RESPONDED DIEEERENTLY TO HABITAT CHANGES CAUSED BY THE BURNING.

KEYS SMALL MAMMALS, BIRDS, SAGEBRUSH, FIRE SUPPRESSION, PRESCRIBED FIRE, WYOMING, SPRING BURN, FALL BURN, POPULATION DENSITY, SPECIES DIVERSITY, GRAND TETON NATIONAL PARK, POSTEIRE SUCCESSION, MOSAIC, DEER MOUSE, 2 
158 AUTH MCGREGOR R. C.

DATE 1958.

TITL SMALL MAMMAL STUDIES ON A SOUTHEAST ALASKA CUTOVER AREA.

PUBL USDA FOR. SERV. STN. PAP. NO. 8. 9P. ALASKA FOR. RES. CENTER, JUNEAU, ALASKA.

ANNO WHITE-FOOTED MOUSE POPULATIONS IN LOGGED AREAS AVERAGED $1.2-4$ PER ACRE. THEY WERE MOST ABUNDANT ON THE VALLEY BOTTOM. SHREWS WERE MOST NUMEROUS ON SIDEHILLS, AND VOLES IN GRASSY AREAS.

KEYS SMALL MAMMALS, ALASKA, LOGGING, POISONS, POPULATION DENSITY, 2, CLEARCUT, WHITE-FOOTED MOUSE, SHREWS, VOLES

159 AUTH MCKAY D. D., VERTS B. J.

DATE 1978.

TITL HABITAT PREEERENCE AND DISPERSAL OE NUTTALLS COTTONTAILS.

PUBL NORTHWEST SCI. 52(4):363-368.

ANNO DISCUSSES THE EFFECT OF SAMPLING BIAS ON THE ESTIMATION OF HABITAT PREFERENCE IN NUTTAILS COTTONTAILS.

KEYS SMALL MAMMALS, NUTTALL'S COTTONTAIL, OREGON, HABITAT, 3

160 AUTH MCKEEVER S.

DATE 1960.

TITL FOOD OF THE NORTHERN FLYING SOUIRREL IN NORTHEASTERN CALIFORNIA.

PUBL J. MAMMAL . 41:270-271.

ANNO DURING THE SUMMER, FUNGI WERE THE PRINCIPLE FOOD OF FLYING SQUIRRELS EXAMINED IN LASSEN COUNTY, CALIFORNIA. HAIR MOSS WAS THE PRINCIPLE FOOD DURING THE WINTER WHEN SNOW COVERED THE GROUND .

KEYS SMALL MAMMALS, FLYING SOUIRRELS, FOOD HABITS, CALIFORNIA, FUNGI, 3

161 AUTH MECH D. L., ROGERS L. L.

DATE 1977.

TITL STATUS, DISTRIBUTION, AND MOVEMENTS OF MARTENS IN NORTHEASTERN MINNESOTA.

PUBL USDA FOR. SERV. RES. PAP. NC-143, 7P. NORTH CENT. FOR EXP. STN., ST. PAUL, MINN.

ANNO INEORMATION ON MARTEN DENSITY AND HABITAT. HOME RANGES OF 4 TELEMETERED MARTEN RANGED EROM 4.3 TO 19.9 KM2.

KEYS MARTEN, MOVEMENTS, POPULATION DENSITY, HABITAT, MINNESOTA, PREDATORS， 3

162 AUTH MEEHAN W.R.

DATE 1974.

TITL THE FOREST ECOSYSTEM OF SOUTHEAST ALASKA. 4. WILDLIFE HABITATS.

PUBL USDA FOR. SERV. GEN. TECH. REP. PNW-16. 32P. PACIFIC NORTHWEST EOREST AND RANGE EXP. STN., PORTLAND, ORE.

ANNO DISCUSSES THE IMPACTS OF MAN'S ACTIVITIES INCLUDING LOGGING, ON WILDLIEE HABITATS.

KEYS SMALL MAMMALS, PREDATORS, ALASKA, LOGGING, HABITAT, LARGE MAMMALS, 3

163 AUTH METZGAR L. H.

DATE 1967.

TITL AN EXPERIMENTAL COMPARISON OF SCREECH OWL PREDATION ON RESIDENT AND TRANSIENT WHITE-FOOTED MICE (PEROMYSCUS LEUCOPUS) .

PUBL J. MAMMAL . 48(3):387-391.

ANNO TRANSIENT MICE WERE MORE SUSCEPTABLE TO PREDATION BY A SCREECH OWL THAN RESIDENT MICE. 
KEYS SMALL MAMMALS, RAPTORS, OWLS, PREDATION, WHITE-FOOTED MOUSE, 2, BIRDS

164 AUTH MILLER R. G., RITCEY R. W., EDWARDS R. Y.

DATE 1955.

TITL LIVE TRAPPING MARTEN IN BRITISH COLUMBIA.

PUBL MURRELET 36(1): 1-8.

ANNO LOGGING AND FIRE DESTROYS MARTEN HABITAT. MODERN CUTTING, MAINTAINING FOREST STANDS OF DIEEERENT AGES, AND PRESERVING OLD GROWTH MARTEN HABITAT, WILL PERPETUATE MARTEN HABITAT.

KEYS MARTEN, BRITISH COLUMBIA, LOGGING, FIRE, HABITAT, HOME RANGE, PREDATORS， 2

165 AUTH MOORE A. W.

DATE 1940.

TITL WILD ANIMAL DAMAGE TO SEED AND SEEDLINGS ON CUTOVER DOUGLAS FIR LANDS OF OREGON AND WASHINGTON.

PUBL U.S. DEP. AGRIC. TECH. BULL. NO. 706. 27P. WASHINGTON, D.C.

ANNO DESCRIBES THE IMPACTS OF WHITE-FOOTED MICE, SHREWS, OTHER MAMMALS, AND BIRDS, ON REFORESTATION.

KEYS SMALL MAMMALS, OREGON, WASHINGTON, DOUGLAS-EIR, SLASH FIRE, LOGGING, SEED, FOOD HABITS, WHITE-FOOTED MOUSE, SHREWS, BIRDS, 3

166 AUTH MOORE A. W.

DATE 1942 .

TITL SHREWS AS A CHECK ON DOUGLAS-FIR REGENERATION.

PUBL J. MAMMAL. 23(1):37-41.

ANNO DISCOVERED SEED EATERS BY LIVETRAPPING WITH SEED FOR BAIT. OREGON COASTAL SHREWS EAT CONSIDERABLE QUANTITIES OF DOUGLAS-EIR SEED AND MAY BE THE REASON THERE ISN'T MORE DOUGLAS-EIR REGENERATION.

KEYS SMALL MAMMALS, SHREWS, SEED, FOOD HABITS, OREGON, DOUGLAS-Fir, SLASH EIRE, 3

167 AUTH MOORE A. W.

DATE 1943.

TITL THE POCKET GOPHER IN RELATION TO YELLOW PINE REPRODUCTION.

PUBL J. MAMMAL. 24(2):271-272.

ANNO IN AREAS GRAZED BY CATTLE, DEER MICE TRAVELING IN POCKET GOPHER BURROWS APPARENTLY CONSUMED PONDEROSA PINE SEED. POCKET GOPHERS WERE NOT EATING THE SEED.

KEYS SMALL MAMMALS, POCKET GOPHERS, DEER MOUSE, GRAZING, OREGON, SEED, PONDEROSA PINE, 3, FOOD HABITS

168 AUTH MORE G.

DATE 1978.

TITL ECOLOGICAL ASPECTS OF FOOD SELECTION IN PINE MARTEN (MARTES AMER ICANA ) .

PUBL M.S. THESIS. UNIV. ALBERTA, EDMONTON. $94 \mathrm{P}$.

KEYS PREDATORS, MARTEN, FOOD HABITS, 2

169 AUTH MORRIS R. D.

DATE 1970.

TITL THE EFEECTS OF ENDRIN ON MICROTUS AND PEROMYSCUS. 1. UNENCLOSED FIELD POPULATIONS.

PUBL CAN. J. ZOOL. 48(4):695-708.

ANNO DEER MOUSE POPULATIONS WERE SIGNIFICANTLY REDUCED AETER

SPRAYING ENDRIN AND DID NOT RECOVER. VOLES DECLINED IMMEDIATELY 
AFTER SPRAYING BUT IN 2 YEARS VOLE POPULATIONS EXCEEDED PRESPRAY LEVELS, AND EXCEEDED POPULATIONS ON CONTROL AREAS EACH YEAR OE THE STUDY.

KEYS SMALL MAMMALS, INSECTICIDE, POPULATION DENSity, DEER MOUSE, MEADOW VOLE, 3

170 AUTH MORRIS R. F., CHESHIRE W. F., MILLER C. A., MOTT D. G.

DATE 1958.

TITL THE NUMERICAL RESPONSE OF AVIAN AND MAMMALIAN PREDATORS DURING A GRADATION OE THE SPRUCE BUDWORM.

PUBL ECOLOGY 39(3):487-494.

ANNO RODENT AND INSECTIVORE POPULATIONS ELUCTUATED INDEPENDANTLY OF BUDWORM DENSITY; HOWEVER, RED-BACKED VOLE AND DEER MOUSE POPULATION CYCLES HAD DEPRESSED PEAKS, POSSIBLY BECAUSE OF SEED SHORTAGE DURING BUDWORM OUTBREAK.

KEYS BIRDS, SMALL MAMMALS, SPRUCE BUDWORM, FOOD HABITS, POPULATION DENSITY, CONIFEROUS FOREST, CANADA, 2

171 AUTH MOTOBU D. A.

DATE 1978.

TITL EEFECTS OF CONTROLLED SLASH BURNING ON THE MOUNTAIN BEAVER (APLODONTIA RUFA RUFA).

PUBL NORTHWEST SCI. 52(2):92-99.

ANNO SLASH BURNING WAS CONSIDERED SUCCESSEUL FOR REDUCING MOUNTAIN BEAVER POPULATIONS. LOSSES WERE A RESULT OF ANIMALS BEING KILLED BY THE FIRE. SURVIVORS REMAINED WITHIN THEIR HOME RANGES. PREDATORS WERE ATTRACTED BY ROTTING CARCASSES.

KEYS SMALL MAMMALS, MOUNTAIN BEAVER, WASHINGTON, SLASH FIRE, MORTALITY, PREDATORS, COYOTE, RAPTORS, LONG-TAILED WEASEL, DOUGLAS-EIR, LOGGING, HOME RANGE, 2

172 AUTH MURIE A.

DATE 1940.

TITL ECOLOGY OF THE COYOTE IN YELLOWSTONE.

PUBL FAUNA OF THE NATIONAL PARKS OF THE U.S. FAUNA SERIES NO 4 . U.S. GOVT. PRINTING OFFICE, WASHINGTON, D.C. 206 P.

ANNO LIEE HISTORY OE THE COYOTE IN YELLOWSTONE NATIONAL PARK. KEYS 1, PREDATORS, COYOTE, YELLOWSTONE NATIONAL PARK, WYOMING, MONTANA

173 AUTH MURIE A.

DATE 1961.

TITL SOME FOOD HABITS OF THE MARTEN.

PUBL J. MAMMAL. 42(4):516-521.

ANNO VOLES WERE PRESENT IN 251 OF 384 MARTEN SCATS. BERRIES WERE IMPORTANT EOOD ITEMS. RED SOUIRREL NESTS WERE USED BY MARTEN FOR A FEW DAYS AT A TIME ALTHOUGH THE SQUIRRELS WERE RARELY PREYED UPON.

KEYS MARTEN, FOOD HABITS, PREDATION, PREDATORS, SMALL MAMMALS, VOLES, RED SOUIRREL, GRAND TETON NATIONAL PARK, PIKA, 2, WYOMING

174 AUTH MURIE O. J.

DATE 1945.

TITL NOTES ON COYOTE FOOD HABITS IN MONTANA AND BRITISH COLUMBIA. PUBL J. MAMMAL. 26(1):33-40.

ANNO NOTES OF EOOD HABITS FROM SCAT COLLECTIONS MADE FROM 1934-1935. IN THESE SCATS SNOWSHOE HARE AND COTTONTAILS WERE THE MOST ABUNDANT FOOD ITEM. CONCLUDES THAT COYOTES WILL SEEK AN 
ABUNDANT AND EASY TO CAPTURE PREY SPECIES.

KEYS COYOTE, PREDATORS, PREDATION, EOOD HABITS, MONTANA, BRITISH COLUMBIA, SMALL MAMMALS, SNOWSHOE HARE, BIRDS, LARGE MAMMALS, 2

175 AUTH NEGUS N. C., FINDLEY J.

DATE 1959.

TITL MAMMALS OE JACKSON HOLE, WYOMING.

PUBL J. MAMMAL. 40(3):371-381.

ANNO LISTING OE SPECIES FOUND IN JACKSON HOLE. HABITAT INEORMATION GIVEN ON SMALL MAMMALS.

KEYS SMALL MAMMALS, PREDATORS, LARGE MAMMALS, WYOMING, HABITAT, 3

176 AUTH NEWBY E. E., MCDOUGAL J. J.

DATE 1964.

TITL RANGE EXTENSION OE THE WOLVERINE IN MONTANA.

PUBL J. MAMMAL. $45(3): 483-487$.

ANNO WOLVERINE INCREASING IN MONTANA.

KEYS PREDATORS, WOLVERINE, MONTANA, POPULATION DENSITY, 3

177 AUTH ODUM E. P.

DATE 1944.

TITL WATER CONSUMPTION OE CERTAIN MICE IN RELATION TO HABITAT SELECTION.

PUBL J. MAMMAL . 25(4):404-405.

ANNO CAPTIVE RED-BACKED VOLES DRANK NEARLY THEIR WEIGHT IN WATER EACH DAY, ALMOST 10 TIMES AS MUCH WATER AS DEER MICE. IN THE WILD THEY CHOSE THE WETTEST HABITAT.

KEYS SMALL MAMMALS, HABITAT, RED-BACKED VOLES, DEER MOUSE, MOISTURE REQUIREMENTS，2，

178 AUTH ODUM E. P., POMEROY S. E., DICKINSON J. C. III, HUTCHESON K. DATE 1973.

TITL THE EFEECTS OF LATE WINTER LITTER BURN ON THE COMPOSITION, PRODUCTIVITY AND DIVERSITY OF A 4-YEAR OLD FALLOW-EIELD IN GEORGIA.

PUBL TALL TIMBERS EIRE ECOL. CONE. 13:399-419.

ANNO SIGMODON, MUS, PEROMYSCUS, AND REITHRODONTOMYS WERE INTRODUCED INTO EENCED, PARTIALLY BURNED PLOTS. SIGMODON INCREASED IN NUMBERS, MUS AND PEROMYSCUS POPULATIONS REMAINED LOW, AND REITHRODONTOMYS BECAME EXTINCT.

KEYS SMALL MAMMALS, COTTON RAT, EASTERN HARVEST MOUSE, OLDEIELD MOUSE, HOUSE MOUSE, PRESCRIBED EIRE, GEORGIA, POPULATION DENSITY, 3

179 AUTH OHMANN L. E., CUSHWA C. T., LAKE R. E., BEER J. R., BRANDER R. B.

DATE 1973.

TITL WILDERNESS ECOLOGY: THE UPLAND PLANT COMMUNITIES, WOODY BROWSE, PRODUCTION, AND SMALL MAMMALS OE TWO ADJACENT 33 -YEAR-OLD WILDEIRE AREAS OE NORTHEASTERN MINNESOTA.

PUBL USDA FOR. SERV. GEN. TECH. REP. NC-7, 3OP. NORTH CENT. FOR. EXP. STN., ST. PAUL, MINN.

ANNO AN ATTEMPT TO RELATE SMALL MAMMAL DISTRIBUTION TO VEGETATIVE COMMUNITY TYPES. INSUEEICIENT NUMBERS OF ANIMALS WERE TRAPPED TO TEST CORRELATIONS, BUT IT APPEARED THAT THE SMALL MAMMALS WERE UNIEORMLY DISTRIBUTED THROUGH THE VEGETATION TYPES TESTED.

KEYS SMALL MAMMALS, MINNESOTA, DEER MOUSE, RED-BACKED VOLES, HABITAT, JACK PINE, BIRCH, ASPEN, 3, WILDEIRE, POST-EIRE SUCCESSION 
180 AUTH ORR-EWING A. L.

DATE 1950.

TITL LIEE HISTORY OE THE DEER MOUSE.

PUBL EOR. CHRON. 26(2):115-126.

ANNO CONTROL OF MICE NECESSARY FOR SUCCESSEUL RESEEDING OF

DOUGLAS-EIR ON LOGGED AND BURNED LAND. SUGGESTS CORRELATING

CONTROL METHODS WITH LIEE HISTORY AND SEASONAL CYCLES OF THE MICE.

KEYS SMALL MAMMALS, DEER MOUSE, LOGGING, PRESCRIBED FIRE, DOUGLAS-EIR, BRITISH COLUMBIA, POPULATION DENSITY， SEED, FOOD HABITS, SHREWS, 3

181 AUTH PANK L. F.

DATE 1974.

TITL A BIBLIOGRAPHY ON SEED-EATING MAMMALS AND BIRDS THAT AEFECT EOREST REGENERATION.

PUBL U.S. DEP. INTERIOR, FISH AND WILDL. SERV. SPEC. SCI. REP., WILDL. NO. 174. WASHINGTON, D.C. 28 P.

ANNO BIBLIOGRAPHY ON SEED-EATING MAMMALS AND BIRDS THAT AEFECT FOREST VEGETATION.

KEYS SMALL MAMMALS, BIRDS, SEED, FOOD HABITS, BIBLIOGRAPHY, 3

182 AUTH PATRIC E. F., WEBB W. L., PATTON D. R., FEOLLIOTT P. F.

DATE 1953.

TITL A PRELIMINARY REPORT ON INTENSIVE BEAVER MANAGEMENT.

PUBL TRANS. NORTH AM. WILDL. CONE. 18:533-539.

ANNO REPORTS HIGH BEAVER POPULATIONS DUE TO EXTENSIVE CLEARCUTTING AND EIRES. SUGGESTS FOREST MANAGEMENT TO PRODUCE SUITABLE BEAVER HABITAT.

KEYS SMALL MAMMALS, BEAVER, NEW YORK, POPULATION DENSITY, WILDFIRE, CLEARCUT, POST-EIRE SUCCESSION, ASPEN, 2

183 AUTH PATTON D.R., FEOLLIOTT P.F.

DATE 1975.

TITL SELECTED BIBLIOGRAPHY OE WILDLIEE AND HABITATS FOR THE SOUTHWEST.

PUBL USDA FOR. SERV. GEN. TECH. REP. RM-16. 39P. ROCKY MT. FOR. AND RANGE EXP. STN., ET. COLLINS, COLO.

ANNO 390 REEERENCES ON RESEARCH AND MANAGEMENT OF IMPORTANT WILDLIEE AND HABITATS IN ARIZONA AND NEW MEXICO. DOES NOT INCLUDE AMPHIBIANS, REPTILES, BATS, OR SMALL RODENTS.

KEYS HABITAT, BIBLIOGRAPHY, ARIZONA, NEW MEXICO, SMALL MAMMALS, LARGE MAMMALS, PREDATORS, BIRDS, 3

184 AUTH PEARSON O. P.

DATE 1964.

TITL CARNIVORE-MOUSE PREDATION: AN EXAMPLE OF ITS INTENSITY AND BIOENERGETICS.

PUBL J. MAMMAL . 45(2): 177-188.

ANNO PEAK MOUSE POPULATION EXCEEDED ITS FOOD SUPPLY. MORTALITY DUE TO CARNIVORES, OTHER SOURCES, AND EMIGRATION, REDUCED MOUSE POPULATIONS SO THAT 7\% OF THE SEED CROP WAS NOT EATEN. EIGHTY-EIGHT PERCENT OF THE 4400 MICROTUS, 33\% OF THE 1200 REITHRODONTOMYS, AND 7\% OE THE 7000 MUS WERE EATEN BY CARNIVORES.

KEYS SMALL MAMMALS, PREDATORS, PREDATION, POPULATION DENSITY, CALIFORNIA, GRAY FOX, RACCOON, SKUNK, SEED, FOOD HABITS, VOLES, HARVEST MOUSE, HOUSE MOUSE, 2 
185 AUTH PELIKAN J., VACKAR J.

DATE 1978.

TITL DENSITIES OF RED FOX, BADGER, AND PINE MARTEN POPULATIONS. PUBL CONG. THERIOL. INT. 2:189.

KEYS PREDATORS, RED FOX, BADGER, MARTEN, POPULATION DENSITY, 2

186 AUTH PILLMORE R. E., FLICKINGER E. L., RICHMOND M. L.

DATE 1970.

TITL FOREST SPRAYING OF ZECTRAN AND ITS SAEETY TO WILDLIEE.

PUBL J. FOR. 69(10):721-727.

ANNO ZECTRAN SPRAYED TO CONTROL SPRUCE BUDWORMS WAS NOT CONSIDERED

HARMEUL TO WILDLIEE. DOCUMENTS THE CONSUMPTION OF SPRUCE

BUDWORM LARVAE BY RED SOUIRREL, AND GOLDEN-MANTLED GROUND SQUIRREL, CHIPMUNKS, AND DEER MOUSE.

KEYS SMALL MAMMALS, BIRDS, INSECTICIDE, EOOD HABITS, SPRUCE BUDWORM, 3, RED SQUIRREL, GOLDEN-MANTLED GROUND SQUIRREL, CHIPMUNKS, DEER MOUSE

187 AUTH QUICK H. F.

DATE 1953.

TITL WOLVERINE, EISHER, AND MARTEN STUDIES IN A WILDERNESS REGION.

PUBL TRANS. NORTH AM. WILDL. CONE. 18:513-532.

ANNO PRESENTS INEORMATION ON RANGE, FOOD HABITS AND BEHAVIOR

GATHERED FROM RUNNING TRAPLINES FOR THESE SPECIES.

KEYS PREDATORS, MARTEN, FISHER, WOLVERINE, TRAPPING, VOLES, SMALL MAMMALS, BRITISH COLUMBIA, 2

188 AUTH OUICK H. E.

DATE 1954.

TITL SMALL MAMMAL POPULATIONS IN NORTHERN BRITISH COLUMBIA.

PUBL CAN. FIELD-NAT. 68(3):95-102.

ANNO SMALL MAMMAL POPULATIONS STUDIED BECAUSE OE THEIR IMPORTANCE AS FOOD ITEMS EOR FUR-BEARERS. DESCRIPTION OE POPULATION CYCLES.

KEYS SMALL MAMMALS, PREDATORS, EISHER, MARTEN, BRITISH COLUMBIA, POPULATION DENSITY, 2

189 AUTH QUICK H. F.

DATE 1955.

TITL FOOD HABITS OE MARTEN (MARTES AMERICANA) IN NORTHERN BRITISH COLUMB I A.

PUBL CAN. FIELD-NAT. 69(4):144-147.

ANNO THE MARTEN FOOD BASE CONSISTS OE RED-BACKED VOLES, DEER MICE, RED SQUIRRELS, AND SNOWSHOE HARE. THESE ANIMALS VARY IN ABUNDANCE BUT LOW LEVELS DID NOT SEEM TO LIMIT MARTEN. THE PROPORTION OF MARTEN SPECIMENS CONTAINING VOLE REMAINS WAS THE SAME DURING LOW VOLE POPULATIONS AS DURING HIGH VOLE POPULATIONS.

KEYS MARTEN, FOOD HABITS, BRITISH COLUMBIA, PREDATORS, PREDATION, RED-BACKED VOLES, DEER MOUSE, RED SQUIRREL, SNOWSHOE HARE, 2

190 AUTH REAM C. H., GRUELL G. E.

DATE 1980.

TITL INELUENCES OF HARVESTING AND RESIDUE TREATMENTS ON SMALL MAMMALS AND IMPLICATIONS EOR FOREST MANAGEMENT.

PUBL IN ENVIRONMENTAL CONSEOUENCES OE TIMBER HARVESTING IN ROCKY MOUNTAIN CONIEEROUS EORESTS. SEP. 11-13, 1979, MISSOULA, MT. GEN. TECH. REP. INT-90.

ANNO REVIEW OF THE EEEECTS OF LOGGING AND RESIDUE TREATMENTS ON SMALL MAMMALS. NUMBERS AND SPECIES COMPOSITION ARE RELATED TO 
HABITATS WHICH RESULT EROM HARVESTING METHODS. DISCUSSION OF BENEFICIAL AND DETRIMENTAL ASPECTS OF SMALL MAMMALS IN FOREST COMMUNITIES.

KEYS SMALL MAMMALS, SPECIES COMPOSITION, POPULATION DENSITY, DEER MOUSE, RED-BACKED VOLES, COLUMBIAN GROUND SOUIRREL, SHREWS, SNOWSHOE HARE, PORCUPINE, FLYING SQUIRRELS, RED SOUIRREL, PRESCRIBED FIRE, BROADCAST EIRE, CLEARCUT, SELECTIVE CUT, HERBICIDE, INSECTICIDE, POST-EIRE SUCCESSION, BROADCAST FIRE, MOSAIC, POISONS, DAMAGE, SEED, FUNGI, INSECTS, RESIDUE TREATMENTS, 1

191 AUTH RESLER R. A.

DATE 1972 .

TITL CLEARCUTTING: BENEFICIAL ASPECTS FOR WILDLIEE RESOURCES.

PUBL J. SOIL WATER CONSERV. 27(6):251-254.

ANNO POINTS OUT POTENTIAL BENEEITS OF CLEARCUTTING TO WILDLIFE IF APPROPRIATE PLANNING PRECEEDS HARVESTING.

KEYS SMALL MAMMALS, LARGE MAMMALS, BIRDS, CLEARCUT, LITERATURE REVIEW, 2

192 AUTH RICKARD W. H.

DATE 1960.

TITL THE DISTRIBUTION OF SMALL MAMMALS IN RELATION TO THE CLIMAX VEGETATION MOSAIC IN EASTERN WASHINGTON AND NORTHERN IDAHO.

PUBL ECOLOGY 41(1):99-106.

ANNO 14 TYPES OF CLIMAX PLANT ASSOCIATIONS SAMPLED FOR SMALL MAMMALS. DISTRIBUTION OF 11 SMALL MAMMAL SPECIES IN DIFEERENT COMMUNITIES DISCUSSED. CHIPMUNKS WERE TRAPPED IN EVERY FOREST STAND. RED-BACKED VOLES WERE TRAPPED IN ALL BUT THE MOST XERIC CONIEEROUS STANDS. SHREWS WERE NOT AS STRONGLY LINKED TO PLANT ASSOCIATIONS AS HERBIVOROUS SMALL MAMMALS.

KEYS SMALL MAMMALS, IDAHO, WASHINGTON, SPECIES COMPOSITION, HABITAT, YELLOW-PINE CHIPMUNK, RED-BACKED VOLES, MASKED SHREW, DUSKY SHREW, DEER MOUSE, 2

193 AUTH ROPPE J. A., HEIN D.

DATE 1978.

TITL EEFECTS OF FIRE IN A LODGEPOLE PINE FOREST.

PUBL SOUTHWEST NAT. 23(2):279-288.

ANNO SPECIES DIVERSITY FOR SMALL MAMMALS AND BIRDS WAS GREATER ON AN 8 YEAR OLD BURN THAN THE ADJACENT UNBURNED LODGEPOLE.

POPULATION DENSITIES AND TOTAL BIOMASS WERE SIMILIAR FOR BOTH HABITATS.

KEYS SMALL MAMMALS, LARGE MAMMALS, BIRDS, LODGEPOLE PINE, COLORADO, WILDEIRE, SPECIES COMPOSITION, POPULATION DENSITY, SUMMER BURN, POST-EIRE SUCCESSION, 1

194 AUTH ROSENZEIG M. L.

DATE 1973.

TITL HABITAT SELECTION BY RODENTS.

PUBL ECOLOGY 54(1):110-117.

ANNO KANGAROO RATS AND POCKET MICE COEXIST, EXPLOITING DIFEERENT VEGETATION STRUCTURES WITHIN THE HABITAT.

KEYS SMALL MAMMALS, RODENTS, HABITAT, KANGAROO RATS, POCKET MOUSE, ARIZONA, VEGETATION STRUCTURE, MESQUITE, 2 
195 AUTH ROWE J. S., SCOTTER G. W.

DATE 1973.

TITL FIRE IN THE BOREAL FOREST.

PUBL QUARTERNARY RES. $3: 444-464$.

ANNO EAUNAL SUCCESSION FOLLOWS PLANT SUCCESSION. FIRE IS IMPORTANT FOR MAINTAINING SOIL CHEMICAL PROPERTIES, VEGETATIONAL COMPOSITION, AND ANIMAL POPULATIONS, THROUGH THE MOSAIC OE HABITATS CREATED.

KEYS FIRE, POST-EIRE SUCCESSION, MOSAIC, LARGE MAMMALS, SMALL MAMMALS, PREDATORS, SNOWSHOE HARE, MARTEN, RED SOUIRREL, BEAVER， 2, WILDEIRE

196 AUTH SAIGO B. W.

DATE 1969.

TITL THE RELATIONSHIP OF NON-RECOVERED RODENT CACHES TO NATURAL REGENERATION OF PONDEROSA PINE.

PUBL M.S. THESIS, OREGON STATE UNIV., CORVALLIS. 98P.

ANNO SMALL MAMMAL SEED CACHES THOUGHT TO BE RESPONSIBLE FOR ONE-HALE OF PONDEROSA PINE REGENERATION. THIS IS MOST IMPORTANT IN AREAS DISTURBED BY ROAD CLEARING, LOGGING AND FIRE. GERMINATING SEED CLUMPS PROVIDE FOOD FOR OREGON JUNCOS AND OTHER ANIMALS. LITERATURE REVIEW ON BENEFICIAL EFFECTS OF SMALL MAMMALS ON REFORESTATION.

KEYS SMALL MAMMALS, FOOD HABITS, PONDEROSA PINE, BIRDS, GOLDEN-MANTLED GROUND SOUIRREL, YELLOW-PINE CHIPMUNK, DEER MOUSE, OREGON JUNCO, LOGGING, WILDEIRE, OREGON, LITERATURE REVIEW， 2

197 AUTH SAMPSON A. W.

DATE 1944.

TITL PLANT SUCCESSION ON BURNED CHAPARRAL LANDS IN NORTHERN CALIFORNIA.

PUBL CALIF. AGRIC. EXP. STN. BULL. 685.

ANNO FIRE KILLS MANY SMALL MAMMALS ESPECIALLY THOSE THAT LIVE IN TREES OR BRUSH. REDUCTION OF SUREACE DWELLING SMALL MAMMALS IS TEMPORARY AND THE INCREASED FOOD SUPPLY AETER FIRE CAUSES AN INCREASE IN THEIR NUMBERS. MOST PREDATORS ARE MOBILE ENOUGH TO ESCAPE MOST FIRES.

KEYS SMALL MAMMALS, PREDATORS, LARGE MAMMALS, BIRDS, FIRE, FOOD HABITS, POPULATION DENSITY, MORTALITY, 2, CHAPARRAL, CALIFORNIA

198 AUTH SCHEFEER T. H.

DATE 1945.

TITL BURROW ASSOCIATIONS OF SMALL MAMMALS.

PUBL MURRELET 26(2)24-26.

ANNO NOTES ON KINDS OF SMALL MAMMALS TRAPPED IN MOLE BURROWS.

KEYS SMALL MAMMALS, PREDATORS, PACIFIC NORTHWEST, HABITAT, REPTILES, WEASEL, MOLES, MICE, POCKET GOPHERS, BULL SNAKE, 3

199 AUTH SCOTTER G. W.

DATE 1964.

TITL EEFECTS OF FOREST FIRES ON THE WINTER RANGE OF BARREN-GROUND CARIBOU IN NORTHERN SASKATCHEWAN.

PUBL WILDL. MANAGE. BULL. SERIES 1(18). CAN. WILDLIFE SERV., OTTAWA. ANNO SNOWSHOE HARE AND BEAVER BENEEITTED EROM POST-FIRE SUCCESSION. RED SOUIRRELS WERE ONLY FOUND IN STANDS OLDER THAN 50 YEARS. EIRE DESTROYED MARTEN HABITAT.

KEYS SMALL MAMMALS, BIRDS, LARGE MAMMALS, POST-FIRE SUCCESSION, MARTEN, PREDATORS, RED SQUIRREL, SNOWSHOE HARE, SASKATCHEWAN, 
BLACK SPRUCE, BEAVER, FIRE, 2

200 AUTH SETON E. T.

DATE 1929.

TITL LIVES OF GAME ANIMALS.

PUBL VOL. II, PART 2. DOUBLEDAY, DORAN AND CO., INC. NEW YORK. $746 \mathrm{P}$. ANNO FIRE CAUSES THE DISAPPEARANCE OF MARTEN.

KEYS MARTEN, FIRE, PREDATORS

201 AUTH SHORT H. L., MCCULLOCH C. Y.

DATE 1977.

TITL MANAGING PINYON-JUNIPER RANGES FOR WILDLIEE.

PUBL USDA FOR. SERV. GEN. TECH. REP. RM-47, 1OP. ROCKY MT. FOR. AND RANGE EXP. STN. EORT COLLINS, COLO.

ANNO DESCRIBES PINYON-JUNIPER HABITATS AND WILDLIEE. DISCUSSES MANAGEMENT PROCEDURES TO BENEEIT WILDLIEE.

KEYS SMALL MAMMALS, LARGE MAMMALS, BIRDS, REPTILES, PINYON-JUNIPER, FOOD HABITS, SOUTHWEST, HABITAT MANAGEMENT, PREDATORS, GRAZING, HERBICIDE, PRESCRIBED EIRE， 3

202 AUTH SIMS H. P., BUCKNER C. H.

DATE 1973.

TITL THE EFEECTS OF CLEARCUTTING AND BURNING OF PINUS BANKSIANA EORESTS ON THE POPULATIONS OF SMALL MAMMALS IN SOUTHEASTERN MANITOBA.

PUBL AMER. MIDL. NAT. $90(1): 228-231$.

ANNO THE TOTAL POPULATION OF SMALL MAMMALS WAS REDUCED AFTER BURNING, BUT FOLLOWED BY A RAPID REESTABLISHMENT OF A LARGE POPULATION OE DEER MICE WHICH WERE CONSIDERED A HAZARD TO DIRECT SEEDING ON JACK PINE SITES IN MANITOBA.

KEYS SMALL MAMMALS, JACK PINE, MANITOBA, FOOD HABITS, DEER MOUSE, CLEARCUT, SLASH EIRE, 2

203 AUTH SOUTIERE E. C.

DATE 1978.

TITL THE EEFECTS OF TIMBER HARVESTING ON THE MARTEN.

PUBL PH.D. DISSERTATION. UNIV. OF MAINE, ORONO. $87 \mathrm{P}$.

KEYS PREDATORS, MARTEN, LOGGING, MAINE, 2

204 AUTH SOUTIERE E. C.

DATE 1979.

TITL EEFECTS OF TIMBER HARVESTING ON MARTEN IN MAINE.

PUBL J. WILDL. MANAGE. 43(4):850-860.

ANNO SELECTIVE TIMBER HARVESTING IS COMPATIBLE WITH THE PRESERVATION OF MARTEN HABITAT. TIMBER HARVESTING DOES NOT LIMIT MARTEN EOOD. CLEARCUTS ARE POOR MARTEN HABITAT FOR THE FIRST FIFTEEN YEARS.

KEYS PREDATORS, MARTEN, MAINE, MEADOW VOLE, SMALL MAMMALS, PREDATION, CLEARCUT, SELECTIVE CUT, BIRDS, MIXED

CONIFER-HARDWOOD, RED-BACKED VOLES, HABITAT， 1, SPRUCE-EIR

205 AUTH SPENCER D. A.

DATE 1955.

TITL THE EEFECTS OF RODENTS ON REFORESTATION.

PUBL PROC. SOC. AM. FORESTERS MEETING, 1955:125-128.

ANNO THIRTEEN ACRE SLASH BURN CONTAINED 50\% EEWER SMALL MAMMALS THAN ADJACENT UNBURNED AREA DURING 6 DAYS IMMEDIATELY AFTER THE EIRE. THERE IS A PROGRESSIVE SHIET IN THE TYPES OF RODENT DAMAGE AT DIEFERENT STAGES OE SUCCESSION. 
KEYS SMALL MAMMALS, SLASH FIRE, POPULATION DENSITY, LOGGING, PACIEIC NORTHWEST., 3, SLASH EIRE

206 AUTH STICKEL L. E.

DATE 1946.

TITL THE SOURCE OF ANIMALS MOVING INTO A DEPOPULATED AREA.

PUBL J. MAMMAL. 27(4):301-307.

ANNO STUDIED THE INVASION OE WHITE-EOOTED MICE EROM ESTABLISHED HOME RANGES TO A CENTRAL AREA WHERE MICE WERE BEING REMOVED BY SNAPTRAPPING.

KEYS SMALL MAMMALS, WHITE-EOOTED MOUSE, MIGRATION, MARYLAND, 2

207 AUTH STODDARD H. L.

DATE 1961.

TITL THE USE OE EIRE ON SOUTHEASTERN GAME LANDS.

PUBL IN THE COOPERATIVE OUAIL STUDY ASSOC. MAY 1, 1931 - MAY 1, 1943. P. 47-63. H. L. STODDARD, H. L. BEADEL AND E. V. KOMAREK. MISC. PUBL. NO. 1. TALL TIMBERS PLANTATION.

ANNO EIRE FOR QUAIL MANAGEMENT ALSO DESTROYS COVER NECESSARY EOR COTTON RATS. POISONING AND TRAPPING RATS IS NOT NECESSARY WHEN EIRE IS USED:

KEYS COTTON RAT, EIRE, POPULATION DENSITY, SOUTHEAST, 3, BIRDS, QUAIL, SMALL MAMMALS

208 AUTH STOUT J., EARRIS A. L., WRIGHT V. L.

DATE 1971.

TITL SMALL MAMMAL POPULATIONS OE AN AREA IN NORTHERN IDAHO SEVERELY BURNED IN 1967.

PUBL NORTHWEST SCI. 45(4):219-226.

ANNO AUTHORS DID NOT DOCUMENT UNUSUAL DENSITIES OF SMALL MAMMALS ON BURN. RODENTS ON BURN WERE EATING SHRUB BARK.

KEYS SMALL MAMMALS, DEER MOUSE, VOLES, POPULATION DENSITY, IDAHO, FOOD HABITS, POST-EIRE SUCCESSION, WILDEIRE, 2

209 AUTH SULLIVAN T. P.

DATE 1979.

TITL REPOPULATION OF CLEAR-CUT HABITAT AND CONIEER SEED PREDATION BY DEER MICE.

PUBL J. WILDL. MANAGE. $43(4): 861-871$.

ANNO MICE CONTINUE TO INVADE RECENT CUT-OVER AREAS AND CONSUME SEED REGARDLESS OE CONTROL METHODS. SUGGESTS USE OF ALTERNATIVE FOODS TO REDUCE CONIEER SEED CONSUMPTION.

KEYS SMALL MAMMALS, CLEARCUT, DEER MOUSE, BRITISH COLUMBIA, DOUGLAS-EIR, SEED, POISONS, MIGRATION, 1

210 AUTH SUNOUIST M. E.

DATE 1967.

TITL EEFECTS OE FIRE ON RACCOON BEHAVIOR.

PUBL J. MAMMAL. 48(4):673-674.

ANNO MOVEMENTS OF A FAMILY OF RADIO-COLLARED RACCOONS WERE FOLLOWED 4 DAYS BEFORE AND 4 DAYS AFTER A EIRE WITHIN THEIR HOME RANGE. THE FIRE DID NOT SIGNIEICANTLY AEEECT THE AMOUNT OE TIME THE ANIMALS SPENT IN THE AREA BURNED.

KEYS SMALL MAMMALS, RACCOON, PRESCRIBED FIRE, SAVANNA, MINNESOTA, 2

211 AUTH TERRILL H. V., MARShALL W. H.

DATE 1946.

TITL USING DEN BOXES TO BOOST SQUIRREL CROP.

PUBL MISSOURI CONSERV. $7: 4-5$. 
ANNO SOUIRRELS DID NOT OCCUPY BURNED AREAS BECAUSE OE LACK OF NEST SITES.

KEYS SMALL MAMMALS, SOUIRRELS, FIRE, HABITAT, 2

212 AUTH TESTER J. R.

DATE 1965.

TITL EEEECTS OF A CONTROLLED BURN ON SMALL MAMMALS IN A MINNESOTA OAK SAVANNA.

PUBL AM. MIDL. NAT. 74(1):240-243.

ANNO AN OAK SAVANNA WAS RETRAPPED 35 DAYS AFTER A EAST HOT

CONTROLLED BURN. THE NUMBER OF DEER MICE INCREASED EROM 4 TO 49 AND THE NUMBER OF RED-BACKED VOLES FROM 9 TO 13. SUGGESTS VOLES NOT AS AFEECTED BY HABITAT CHANGES CAUSED BY EIRE IN A SAVANNA, AS IN CONIEER SLASH.

KEYS SMALL MAMMALS, DEER MOUSE, RED-BACKED VOLES, OAK-SAVANNA, MORTALITY, POPULATION DENSITY, MINNESOTA, PRESCRIBED FIRE， 2

213 AUTH TESTER J. R., MARShALL W. H.

DATE 1962 .

TITL MINNESOTA PRAIRIE MANAGEMENT TECHNIOUES AND THEIR WILDLIEE IMPLICATIONS.

PUBL TRANS. NORTH AM. WILDL. NAT, RESOUR, CONE. 27:267-287.

ANNO MEADOW VOLE INCREASED WITH INCREASING LITTER AETER FIRE, WHILE DEER MICE DECREASED.

KEYS SMALL MAMMALS, GRASSLAND, MINNESOTA, WILDEIRE, MEADOW VOLE, DEER MOUSE, POPULATION DENSITY, SPRING BURN, FALL BURN, GRAZING, MOWING, BIRDS, 2

214 AUTH TEVIS L. JR.

DATE 1953.

TITL STOMACH CONTENTS OF CHIPMUNKS AND MANTLED SQUIRRELS IN NORTHEASTERN CALIEORNIA.

PUBL J. MAMMAL. 34:316-324.

ANNO HYPOGEOUS FUNGI ARE THE MOST IMPORTANT EOOD OF CHIPMUNKS AND MANTLED SQUIRRELS IN THE COMMERCIAL TIMBER BELT OF NORTHEASTERN CALIEORNIA. SEEDS, LEAVES, FLOWERS, FRUITS, ROOTS, ARTHROPODS, AND MEAT WERE ALSO EATEN. CONCLUDES SMALL MAMMALS THAT ARE HARMEUL AT ONE TIME AND PLACE MAY BE BENEEICIAL AT ANOTHER TIME OR PLACE.

KEYS SMALL MAMMALS, CHIPMUNKS, GOLDEN-MANTLED GROUND SOUIRREL, FOOD HABITS, CALIEORNIA, 2, DOUGLAS-EIR

215 AUTH TEVIS L. JR.

DATE 1956.

TITL EEEECT OF A SLASH BURN ON FOREST MICE.

PUBL J. WILDL. MANAGE. 20(4):405-409.

ANNO EXPERIMENT TO SEE IF SLASH FIRE COULD BE USED TO CONTROL SEED EATING MICE. MOST MICE IN SLASH WERE KILLED BY THE EIRE. AS SOON AS THE ASH SUREACE WAS HARDENED BY RAIN THERE WAS A REINVASION OF MORE MICE THAN ORIGINALLY INHABITED THE SLASH.

KEYS SMALL MAMMALS, WHITE-FOOTED MOUSE, CHIPMUNKS, WOODRATS, SHREWS, MORTALITY, MIGRATION, SOIL SUREACE, DOUGLAS-FIR, CALIFORNIA, POPULATION DENSITY, CLEARCUT, SLASH FIRE, I

216 AUTH TEVIS L. JR.

DATE 1956.

TITL INVASION OF A LOGGED AREA BY GOLDEN-MANTLED SOUIRRELS.

PUBL J. MAMMAL. $37(2): 291-292$. 
ANNO GOLDEN-MANTLED SQUIRRELS MIGRATED EROM AN ISOLATED RIDGE WHERE A POPULATION WAS ESTABLISEED, THROUGE VIRGIN DOUGLAS-EIR TO ESTABLISH POPULATIONS IN NEWLY LOGGED AREAS. SOUIRRELS' SEED EATING HABITS RERRESENTED A THREAT TO REEORESTATION. POPULATION INCREASED IN SPITE OE POISONING.

KEYS SMALL MAMMALS, GOLDEN-MINTLED GROUND SQUIRREL, LOGGING, DOUGLAS-EIR, CALIEORNIA, WHITE EIR, EOOD HABITS, SEED, MIGRATION, 1

217 AUTH TEVIS L. JR.

DATE 1956.

TITL POCKET GORHERS AND SEEDLINGS OE RED EIR.

EUBL ECOLOGY $37(2): 379-381$.

ANNO IDAHO EESCUE HAD PREVENTED SPREAD OE CONIEERS. OVERGRAZING CAUSED DISTRUCTION OE TURE AND MULTIPLICATION OE BULBOUS PLANTS. POCKET GOPHERS RESPONDED BY INCREASING. GROUND CHURNED BY POCKET GOPHERS PRODUCED AN IDEAL SEED BED EOR CONIEERS. IN 1951 A BUMPER CROP OE RED EIR CONES PRODUCED MANY SEEDLINGS. THERE WAS ABUNDANT SURVIVAL OE SEEDLINGS ON BARE GROUND AWAY EROM RODENTS.

KEYS SMALI MAMMALS, POCKET GOPHERS, GRAZING, EOOD HABITS, SEED, RED EIR, IDAHO EESCUE, CALIFORNIA, PREDATORS, COYOTE, 2

218 AUTH TEVIS L. JR.

DATE 1956.

TITL RESPONSES OE SMALL MAMMAL POPULATIONS TO LOGGING DOUGLAS-FIR.

PUBL J. MAMMAL. $37(2) 189-196$.

ANNO LOGGING CAUSES AN INCREASE IN THE NUMBERS OE TOWNSEND CHIPMUNKS, DUSKY-EOOTED WOOD RATS, WHITE-EOOTED AND BIG-EARED MICE, DIGGER SQUIRREIS, CHICKAREES, GRAY SOUIRRELS, AND BUSH RABBITS. TROWBRIDGE SHREWS, RED-BACKED MICE, ELYING SOUIRRELS AND SHREW-MOLES DECREASE. WHITE-EOOTED MICE AND TOWNSEND'S CHIPMUNKS BECOME MOST NUMEROUS AND ARE RESPONSIBLE EOR MOST OE THE SEED DESTRUCTION.

KEYS SMALI MAMMAS, MORTALITY, DOUGLAS-EIR, LOGGING, SLASA EIRE, EOOD HABITS, SEED, CALIEORNIA, MIGRATION, TOWNSEND'S CHIPMUNK, WEITE-EOOTED MOUSE, PINON MOUSE, CALIEORNIA GROUND SQUIRREI, DUSKY-EOOTED WOOD RAT, GRAY SOUIRREL, ELYING SQUIRRELS, DOUGLAS' SQUIRREL, BRUSH RABEIT, TROWBRIDGE SHREW, RED-BACKED VOIES, SHREW-MOLE, 2, POPULATION DENSITY

219 AUTH TRAPPE J. M. MASER C.

\section{DATE 1977.}

TITL

ECTOMYCORRHIZAL EUNGI: INTERACTIONS OE MUSHROOM AND TRUEZLES WITH BEASTS FND TREES.

PUBL IN MUSEROOMS AND MAN--AN INTERDISCIPLINARY APPROACH TO MYCOLOGY. P. 163-180. A. B. WALTERS, ED. IINN-BENTON COMMUNITY COLLEGE, ALBANY, ORE.

ANNO SMALL MAMMALS, EORESTS, AND MYCORRHIZAL EUNGI HAVE EVOLVED TOGETHER AND ARE NUTUALTY DEPENDANT. SMALL MAMIALS ARE THE PRIMARY DISPERSAL AGENT EOR HYPOGEOUS EUNGI.

KEYS SMALL MAMMALS, EOOD FABITS, MYCORRHIZAL EUNGI, 2

220 AUTE TRUETT J. C.

DATE 1979.

TITL OBSERVATIONS OE COYOTE PREDATION ON MULE DEER EAWNS IN ARIZONA. PUBL J. WILDL. MANAGE. 43(4):956-958.

ANNO DESCRIPTIONS OE COYOTE ATTACKS ON MULE DEER EAWNS AND DEEENSE OE EAWNS BY DOES. 
KEYS PREDATORS, COYOTE, MULE DEER, ARIZONA, PREDATION, 2

221 AUTH TRYON C. A. JR.

DATE 1947.

TITL THE BIOLOGY OE THE POCKET GOPHER (THOMOMYS TALPOIDES) IN MONTANA.

PUBL MONT. STATE COLL. AGRIC. EXP. STN. BULL. 448. 33 P.

ANNO LIEE HISTORY AND IMPORTANCE OE THE POCKET GOPHER AS A BURROWING ANIMAL IN WESTERN MOUNTAINS.

KEYS SMALI MAMMALS, POCKET GOPHERS, MONTANA, HABITAT, EOOD HABITS, 3

222 AUTH TURNER G. T., HANSEN R. M., REID V. H., TIETJEN H. P., WARD A. L.

DATE 1977.

TITL POCKET GOPHERS AND COLORADO RANGE LANDS.

PUBL BULLETIN 5545, COLO. STATE UNIV. EXP. STN., FT. COLLINS, COLO.

ANNO A COMPLETE LIEE HISTORY OE POCKET GOPHERS. INCLUDES SECTION ON CONTROL .

KEYS SMALL MAMMALS, POCKET GOPHERS, COLORADO, HABITAT, FOOD HABITS, POISONS, HERBICIDE, 2

223 AUTH USDA

DATE 1978.

TITL SPECIES LIST BIRDS, MAMMALS, EISH, REPTILES, AND AMPHIBIANS FOR THE EOREST SERVICE INCLUDING SEPARATE LISTS EOR IDAHO, MONTANA AND NORTH DAKOTA.

PUBL USDA FOR. SERV., NORTHERN REGION, MISSOULA, MONT., R1-78-002 82P.

ANNO SPECIES LISTS EOR EACH STATE IN THE NORTHERN REGION.

KEYS SMALL MAMMALS, LARGE MAMMALS, BIRDS, EISH, REPTILES, AMPHIBIANS, MONTANA, IDAHO, NORTH DAKOTA, 3

224 AUTH VIERECK I. A., DYRNESS C. T. (EDS.)

DATE 1979 .

TITL ECOLOGICAL EEEECTS OE THE WICKERSHAM DOME FIRE NEAR FAIRBANKS, ALASKA.

PUBL USDA EOR. SERV. GEN. TECH. REP. PNW-90, 71P. PAC. NORTHWEST RANGE AND EXP. STN., PORTLAND, ORE.

ANNO RED-BACKED VOLES WERE REDUCED AETER THE FIRE, AND DID NOT OVER WINTER IN THE BURN UNTIL 3 YEARS LATER. THE RELATIVELY RARE TUNDRA VOLE BECAME NUMEROUS ON THE BURNED AREA 3 YEARS AETER THE EIRE. SNOWSHOE HARE POPULATIONS WERE HIGH ( 6 HARES PER HECTARE) AND CONSUMED LARGE QUANTITIES OE WILLOW SPROUTS AND CHARRED BARK DURING THE EALL AND WINTER AETER THE EIRE.

KEYS SMALL MAMMALS, RED-BACKED VOLES, TUNDRA VOLE, SNOWSHOE HARE, WILDEIRE, ALASKA, POST-EIRE SUCCESSION, BLACK SPRUCE, 2, HABITAT

225 AUTH VOGL R. J.

DATE 1967.

TITL CONTROLLED BURNING FOR WILDLIEE IN WISCONSIN.

PUBL TALL TIMBERS EIRE ECOL. CONE. 6:47-96.

ANNO HISTORICAL ACCOUNT OE THE IMPORTANCE OE EIRE IN MAINTAINING GRASSLANDS IN WISCONSIN AND THE SIGNIEICANCE OE PRAIRIE AND SAVANNA HABITATS TO WILDLIEE.

KEYS BIRDS, MULE DEER, SMALL MAMMALS, DIRECT EEEECTS, POST-EIRE SUCCESSION, MORTALITY, HABITAT, WISCONSIN, PRESCRIBED FIRE, 2 
226 AUTH VOGL R. J.

DATE 1973.

TITL EEFECTS OF FIRE ON THE PLANTS AND ANIMALS OF A FLORIDA WETLAND.

PUBL AM. MIDL. NAT. 89:334-347.

ANNO NO BIRD OR MAMMAL INJURY WAS OBSERVED DUE TO FIRE. SOME

AMPHIBIANS AND REPTILES WERE KILLED. FOUR MONTHS AETER THE EIRE MAMMAL POPULATIONS OF BURNED AND UNBURNED AREAS APPEARED

SIMILAR.

KEYS BIRDS, REPTILES, MORTALITY, AMPHIBIANS, SMALL MAMMALS, FLORIDA, WETLAND, PRESCRIBED EIRE, 2

227 AUTH VOLLAND L. A.

DATE 1974.

TITL RELATION OE POCKET GOPHERS TO PLANT COMMUNITIES IN THE PINE REGION OE CENTRAL OREGON.

PUBL IN WILDLIEE AND FOREST MANAGEMENT IN THE PACIFIC NORTHWEST. P. 149-166. H. C. BLACK, ED. PROC. 1973 SYMP. ORE. STATE UNIV., CORVALIIS.

ANNO GOPHERS PREEER LODGEPOLE FORESTS WITH LUSH STANDS OE LONG-STOLEN SEDGE AND/OR EORBS. WHEN LOGGING OR BURNING OCCURS ADJACENT TO THESE COMMUNITIES, INVASION BY GOPHERS CAN BE EXPECTED.

KEYS SMALL MAMMALS, POCKET GOPHERS, OREGON, PONDEROSA PINE, LODGEPOLE PINE, HABITAT, 1

228 AUTH VREELAND H., LUGASKI T., VREELAND P.

DATE 1979.

TITL INTEGRATED ECOLOGY OF THE GREAT BASIN. PART III. A PRELIMINARY ANALYSIS OE NOWARK SUMMIT, EUREKA COUNTY, NEVADA.

PUBL NORTHWEST SCI. 53(3):180-189.

ANNO VEGETATIONAL COMMUNITY IS A GOOD INDICATOR OE ANIMAL SPECIES AND THEIR POPULATION SIZES. DESCRIBES HABITAT PREEERENCES OE DIEEERENT SMALL MAMMAL SPECIES.

KEYS SMALI MAMMALS, GREAT BASIN, SAGEBRUSH-GRASS, GRAZING, HABITAT, LEAST CHIPMUNK, DEER MOUSE, GREAT BASIN POCKET MOUSE, MONTANE VOLE, BUSHY-TAILED WOODRAT, 2

229 AUTH WANGERSKY P. J., CUNNINGHAM W. J.

DATE 1957.

TITL TIME LAG IN PREY-PREDATOR POPULATION MODELS.

PUBL ECOLOGY 38(1):136-139.

ANNO AETER DEEINING THE PARAMETERS OE PREY AND PREDATOR POPULATIONS, POPULATION EQUATIONS ARE MOST EASILY HANDLED BY APPROXIMATION ON AN ANALOG COMPUTER.

KEYS PREDATION, 3

230 AUTH WECKWERTH R. P., HAWLEY V. D.

DATE 1962.

TITL MARTEN FOOD HABITS AND POPULATION FLUCTUATIONS IN MONTANA.

PUBL J. WILDL. MANAGE. 26(1):55-74.

ANNO FLUCTUATIONS IN PREY SPECIES NUMBERS AEEECTED THE NUMBER OF MARTEN IN THIS AREA. FOOD ITEMS WERE GENERALLY USED IN PROPORTION TO THEIR ABUNDANCE EXCEPT WHEN AEEECTED BY AVAILABILITY OR PREEERENCE BY MARTEN. MICROTUS AND CLETHRIONOMYS WERE PREEERRED MAMMALIAN FOODS.

KEYS MARTEN, EOOD HABITS, MONTANA, PREDATORS, POPULATION DENSITY, SMALL MAMMALS, 1 
231 AUTH WEST S. D.

DATE 1974.

TITL POST-BURN POPULATION RESPONSE OF THE NORTHERN RED-BACKED VOLE, CLETHRIONOMYS RUTILUS IN INTERIOR ALASKA.

PUBL M.S. THESIS, UNIV. ALASKA, FAIRBANKS. 66P.

KEYS SMALL MAMMALS, RED-BACKED VOLES, ALASKA, POST-FIRE SUCCESSION, WILDEIRE， 2

232 AUTH WEST S. D.

DATE 1979.

TITL HABITAT RESPONSES OF MICROTENE RODENTS TO CENTRAL ALASKAN FOREST SUCCESSION.

PUBL PH.D. THESIS. UNIV. CALIF., BERKELEY. 115P.

KEYS SMALL MAMMALS, VOLES, ALASKA, PLANT SUCCESSION, HABITAT, 2

233 AUTH WILLIAMS 0.

DATE 1955.

TITL DISTRIBUTION OF MICE AND SHREWS IN A COLORADO MONTANE FOREST.

PUBL J. MAMMAL. 36(2):221-231.

ANNO GIVES HABITAT TYPES IN WHICH VARIOUS SMALL MAMMALS WERE TRAPPED.

KEYS SMALL MAMMALS, SHREWS, WHITE-FOOTED MOUSE, RED-BACKED VOLES, ROCKY MOUNTAIN PHENACOMYS, MEADOW VOLE, WESTERN JUMPING MOUSE, HABITAT, COLORADO, 3

234 AUTH WILLIAMS 0.

DATE 1959.

TITL FOOD HABITS OF THE DEER MOUSE.

PUBL J. MAMMAL. $40(3): 415-419$.

ANNO SEEDS MADE UP TWO-THIRDS TO THREE-FOURTHS OF THE MATERIAL EOUND IN THE STOMACHS OF DEER MICE COLLECTED IN WYOMING AND COLORADO. ONE-TENTH TO ONE-EIFTH OF THE MATERIAL CONSISTED OF INSECT AND ARACHNID REMAINS.

KEyS SMALl MAMMALs, DEER MOUSE, FOOD HABItS, COLORADO, MONTANA, 2

235 AUTH WOLEF J. 0.

DATE 1978.

TITL FOOD HABITS OF SNOWSHOE HARES IN INTERIOR ALASKA.

PUBL J. WILDL. MANAGE. 42(1):148-153.

ANNO DESCRIBES FOOD HABITS OF SNOWSHOE HARES IN ALASKA.

KEYS SNOWSHOE HARE, FOOD HABITS, ALASKA, SMALL MAMMALS, 3

236 AUTH YEAGER L. E.

DATE 1950.

TITL IMPLICATIONS OF SOME HARVEST AND HABITAT FACTORS ON PINE MARTEN MANAGEMENT.

PUBL TRANS. NORTH AM. WILDL. CONE. 15:319-334.

ANNO THE IMMEDIATE EEFECT OF FIRE ON MARTEN POPULATIONS IS DESTRUCTIVE. LOGGING AND GRAZING ARE SLOWLY CONSUMING MARTEN HABITAT. RECOMMENDS NOVEMBER-DECEMBER TRAPPING SEASONS BECAUSE MORE MALES ARE TRAPPED DURING THIS TIME AND COULD BE REMOVED AS SURPLUS POPULATION, YIELDS OF HIGH OUALITY PELTS, AND BETTER CONDITIONS FOR TRAPPING.

KEYS MARTEN, HABITAT, FIRE, LOGGING, GRAZING, TRAPPING, 2 
237 AUTH YEAGER L. W.

DATE 1961.

TITL CLASSIEICATION OE NORTH AMERICAN MAMMALS AND BIRDS ACCORDING TO EOREST HABITAT PREEERENCE.

PUBL J. EOR. 59(9):671-674.

ANNO CLASSIEICATION OE BIRDS AND MAMMALS BY FOREST HABITAT PREEERENCE.

KEYS BIRDS, SMALL MAMMALS, LARGE MAMMALS, HABITAT, 2 
Abramsky, Z. 1

Adamcik, R. S. 123

Adams, L. 2-4

Adelman, E. 5

Agee, J. K. 6

Ahlgren, C. E. 7, 8, 135

Aldous, C. M. 61

Ambrose, H. W. 9

Ambrose, R. E. 10

Amdelt, W. F. 11, 12

Anderson, R. J. 13

Aumann, G. D. 14

Baker, R. H. 15

Baker, W. W. 16

Barmore, W. J., Jr. 17

Barnes, V. G. 13

Barnes, V. G., Jr. 18

Beall, R. 127

Beck, A. M. 19

Beer, J. R. 179

Bendell, J. F. 20, 21

Bergstrom, D. 22

Bernard, S. R. 23

Biswell, H. H. 24

Black, H. C. 25-27, 30, 39, 71, 112

Bock, C. E. 28, 29

Bock, J. H. 28, 29

Borrecco, J. E. 30

Brabant, A. 31

Brand, C. J. 32, 33, 123

Brander, R. B. 179

Broadbrooks, H. E. 34

Brown, K. F. 23

Bruce, A. M. 13

Bruner, A. 127

Buckley, J. L. 138

Buckner, C. H. 202

Buckner, J. L. 35

Buech, R. R. 36

Buechner, H. K. 37

Burns, S. 38

Burton, D. H. 39

Butterworth, B. B. 40

Campbell, T. M. 41

Cheschire, W. F. 170

Chew, R. M. 40

Childs, H. E., Jr. 116

Clark, T. W. 41

Cleary, B. D. 42

Clothier, R. R. 43

Cook, D. B. 90

Cook, S. F., Jr. 44

Costa, R. 45

Cowan, I. McT. 46

Cowles, R. B. 47

Crawford, H. S. 145

Cross, S. P. 65

Crouch, G. L. 48,49
Cunningham, W. J. 229

Cushwa, C. T. 179

Czuhai, E. 145

Darnell, R. M. 139

Davis, P. R. 50

De Vos, A. 51, 52

Debyle, N. V., Ed. 53

Dice, L. R. 54

Dickinson, J. C. III, 178

Dieterich, J. H. 142

Dimock, E. J. 25

Dimock, E. J. II, 55

Dyer, M. I. 1

Dyrness, C. T. 224

Eadie, W. R. 56

Eastman, J. 57

Edgerton, P. J. 58

Edwards, R. Y. 59, 164

Ellison, L. 60, 61

Elsing, D. 36

Evans, J. 25

Evans, K. E. 62

Fala, R. A. 63

Farris, A. L. 208

Fenner, R. L. 116

Ffolliott, P. F. 45, 142, 182

Findley, J. 175

Fischer, C. A. 33

Fisher, E. L. 64

Fisher, J. L. 65

Fitch, H. S. 66, 67

Flickinger, E. L. 186

Fogel, R. D. 68

Fowells, H. A. 69

Fox, J. F. 70

Fredriksen, R. L. 145

Frenzel, R. W. 71

Friday, G. P. 72

Garman, E. H. 73

Gashwiler, J. S. 74-80, 153

Getz, L. L. 81

Gipson, P. S. 11, 12

Givens, L. S. 82

Gloyd, H. K. 102

Godfrey, G. K. 83

Graham, S. A. 84

Grange, W. 85

Greaves, R. D. 42

Grechman, R. 40

Gruell, G. E. 190

Gullion, G. W. 86

Gunderson, H. L. 87

Halvorson, C. H. 88

Hamilton, W. J., Jr. 89, 90

Hanavan, M. G. 4

Handley, C. O., Jr. 91

Hansen, L. P. 92

Hansen, R. M. 119, 120, 222
Hanson, E. E. 93, 94

Harlow, R. F. 145, 146

Harris, A. S. 95

Harrison, P. D. 1

Hartesveldt, R. J. 96, 97

Harvey, H. T. 96, 97

Hawley, V. D. 98, 230

Hayden, P. 17

Hayward, C. L. 99

Healey, M. C: 100

Hein, D. 193

Hermann, R. K. 42

Hickie, P. 101

Hisaw, F. L. 102

Hoffman, G. R. 103

Hoffman, R. S. 104

Hooven, E. F. 30, 105-112

Hooven, E. H. 26

Horn, E. E. 113

Hornocker, M. G. 128

Horton, J. 114

Hosley, N. W. 4

Houtcooper, W. C. 115

Howard, W. E. 116

Hurley, J. F. 64

Hutcheson, K. 178

Ingram, R. 117

Jameson, E. W., Jr. 118

Johnson, D. R. 119

Johnson, D. W. 4

Johnson, M. K. 120

Jones, J. H. 121

Julander, O. 151

Keith, L. B. 32, 33, 122, 123

Kerfoot, W. C. 140

Kipp, D. H. 124

Kirkland, G. L., Jr. 125

Kirkpatrick, R. C. 126

Klebenow, D. R. 127

Koehler, G. M. 128, 129

Komarek, E. V., Sr. 130-132

Komarek, R. 133

Korschgen, L. J. 134

Krefting, L. W. 135

Lake, R. E. 179

Landers, J. L. 35

Lawrence, G. E. 136

Lawrence, W. H. 137

Lensink, C. J. 138

Lobue, J. 139

Long, C. A. 140

Lowe, P.O. 141, 142

Lowrie, J. C. 112

Lubina, J. A. 143

Lugaski, T. 228

Lutz, H. J. 144

Lyon, L. J. 145

Mackay, R. H. 46 
Manville, R. H. 146

Marshall, J. T., Jr. 147

Marshall, W. H. 148-150, 211, 213

Marston, R. B. 151

Martell, A. M. 152

Maser, C. 153-155, 219

Mason, R. 127

McCulloch, C. Y. 201

McDougal, J. J. 176

McGee, J. M. 156, 157

McGregor, R. C. 158

McKay, D. D. 159

McKeever, S. 160

McKnight, J. R. 29

Mech, D. L. 161

Meehan, W. R. 162

Metz, L. J. 145, 146

Metzgar, L. H. 163

Miller, C. A. 170

Miller, R. G. 164

Moore, A. W. 165-167

Moore, W. R. 129

More, G. 168

Morris, D. W. 80

Morris, R. D. 169

Morris, R. F. 170

Motobu, D. A. 171

Mott, D. G. 170

Murie, A. 172, 173

Murie, O. J. 174

Negus, N. C. 175

Newby, F. E. 98, 176

Nussbaum, R. A. 154

Odum, E. P. 177, 178

Ohmann, L. F. 179

Orr-Ewing, A. L. 73, 180

Pank, L. F. 181

Patric, E. F. 182

Pattie, D. L. 104

Patton, D. R. 45, 142, 182, 183

Pearson, H. A. 145, 146

Pearson, O. P. 184

Pelikan, J. 185

Pillmore, R. E. 186

Pomeroy, S. E. 178

Probasco, G. E. 62

Quick, H. F. 187-189

Radtke, R. E. 36

Ream, C. H. 190

Reid, V. H. 222

Resler, R. A. 191

Richmond, M. L. 186

Rickard, W. H. 192

Ritcey, R. W. 164

Robinette, W. L. 80

Rochelle, J. A. 25

Rogers, L. L. 161

Roppe, J. A. 193

Rosenzeig, M. L. 194

Roundy, B. 127

Rowe, J. S. 195

Rush, D. H. 123
Saigo, B. W. 196

Sampson, A. W. 197

Scheffer, T. H. 198

Schubert, G. H. 69

Scotter, G. W. 195, 199

Seton, E. T. 200

Sheldon, H. L. 36

Shellhammer, H. S. 97

Short, H. L. 201

Siderits, K. 36

Sims, H. P. 202

Skoog, R. O. 138

Smith, N. S. 121

Soutiere, E. C. 203, 204

Spencer, D. A. 205

Stager, W. 127

Starkey, E. E. 71

Stecker, R. E. 97

Stickel, L. F. 206

Stoddard, H. L. 207

Stout, J. 208

Sullivan, T. P. 209

Sunquist, M. E. 210

Surrendi, P. C. 122

Taber, R. D. 27

Taylor, A. R. 129

Taylor, D. 17

Terrill, H. V. 211

Tester, J. R. 212, 213

Tevis, L., Jr. 214-218

Thomas, J. W. 58

Tietjen, H. P. 222

Todd, A. W. 123

Trappe, J. M. 68, 154, 155, 219

Truett, J. C. 220

Tryon, C. A., Jr. 221

Turner, G. T. 222

Ure, D. C. 155

USDA 223

Vackar, J. 185

Verts, B. J. 160

Viereck, L. A. 224

Vogl, R. J. 19, 225, 226

Volland, L. A. 227

Vreeland, H. 228

Vreeland, P. 228

Wangersky, P. J. 229

Ward, A. L. 222

Ward, K. 127

Warnock, J. E. 92

Webb, W. L. 182

Weckwerth, R. P. 230

West, S. D. 231, 232

Williams, O. 233, 234

Wolff, J. O. 235

Wright, V. L. 208

Yeager, L. E. 236

Yeager, L. W. 237 


\section{KEYWORDS Geographical Area}

Alaska 85, 93, 95, 138, 144, 158, 162, 224, 231, 232, 235

Alberta 32, 33, 46, 85, 122

Arizona 28, 29, 45, 121, 141, 142, 183, 194, 220

British Columbia 59, 73, 85, 100, 164, 174, 180, 187189,209

California 24, 40, 44, 47, 66, 71, 116, 136, 143, 160, 184, $197,214-218$

Canada 48, 70, 170

Colorado, 1, 119, 193, 222, 233, 234

England 83

Florida 226

Georgia 35, 178

Glacier National Park 98

Grand Teton National Park 17, 41, 156, 157, 173

Great Basin 228

Idaho 2, 4, 103, 120, 128, 129, 148, 150, 192, 208, 223

Indiana 115

Lava Beds National Monument 71

Maine 203, 204

Manitoba 202

Maryland 206

Michigan 54, 84, 137

Minnesota 7, 8, 36, 85, 87, 135, 161, 179, 210, 212, 213

Missouri 134

Montana 2, 3, 5, 43, 88, 98, 104, 146, 149, 150, 172, 174, $176,221,223,230,234$

Nebraska 11, 12॰

Nevada 80, 127

New England 81

New Mexico 183

New York 182

North Dakota 223

Ontario 20

Oregon $18,25,26,30,39,42,49,58,76-79,105-107$, 109-112, 117, 147, 154, 159, 165-167, 196, 227

Pacific Northwest 74, 75, 101, 198, 205

Pennsylvania 63

Saskatchewan 199

Southeast 82, 130, 207

Southwest 201

Tennessee 10

Texas 15, 37

United States 48

Utah 60, 61, 80, 99, 151

Washington 25, 34, 94, 103, 165, 171, 192

West Virginia 125

Western United States 23

Wisconsin 19, 85, 124, 225

Wyoming 2, 41, 50, 140, 156, 157, 172, 173, 175

Yellowstone National Park 172

\section{Treatments}

Fire $-5,21,31,52,54,61,69,86,108,117,126,137$, $143,145,164,195,197,199,200,207,211,236$ Wildfire $6,17,26,29,36,40,44,50,57,59,70,85$, $91,96,106,114,122,124,128,129,131-133$,
$135,141,142,144,179,182,193,195,196$, $208,213,224,231$

Prescribed fire $7,8,15,19,24,28,35,55,63,64$, $71,82,94,106,113,116,127,130,133,135$, $156,157,178,180,190,201,210,212,225$, 226

Broadcast fire 53, 88, 190

Slash fire $26,73,74,79,109,112,165,166,171$, $202,205,215,218$

Spring burn 156, 157, 213

Summer burn 193

Fall burn 124, 156, 157, 213

Fire suppression 150,157

Logging $-5,8,18,26,41,45,52,54,55,58,89,95,101$, $106-108,112,113,117,129,137,150,151,158$ $162,164,165,171,180,196,203,205,216,218,236$

Clearcut $10,18,26,45,50,53,63,74-79,88,108$ $110,125,158,182,190,191,202,204,209$, 215

Selective cut $10,34,190,204$

Residue treatments $10,55,190$

Slash 64

Other Treatments

Disking 35

Herbicide 26, 30, 49, 119, 190, 201, 222

Insecticide 2, 169, 186, 190

Fuels 64

Grazing $15,28,37,60,61,101,167,201,213$, $217,228,236$

Mowing 139, 213

Poisons 69, 77, 111, 158, 190, 209, 222

Strip-mining 92

Trapping 67, 112, 187, 236

\section{Effects of Treatments}

Longterm fire effects 59

Plant succession 5, 92, 101, 110, 125, 137, 232

Postfire succession $8,17,21,26,47,63,70,79,85,88$, $106,108,109,135,142,156,157,179,182,190$, $193,195,199,208,224,225,231$

Fire disclimax 19

Mosaic 21, 94, 129, 190, 195

Snags 16,38

Vegetation structure $1,4,19-21,41,56,58,72,88,113$, $119,139,143,145,194$

\section{Fire Effects on Soil and Moisture}

Nutrients 21

Sodium 14

Soil 61

Soil aeration 90

Soil characteristics 6,110

Soil compaction 61

Soil erosion 60

Soil surface 215

Microclimate 21, 81

Moisture requirements 81,178

Relative humidity 136 


\section{Population Characteristics}

Behavioral adaptations 91, 131, 132

Damage 25, 42, 48, 55, 75, 107, 190

Food habits 2, 3, 7, 8, 19-22, 28, 34, 35, 39, 43, 44, 46, $49,53,57,59,63,67-70,75,76,78,84,88-90,96,97$, $99,101,105-108,111,113,115,118-120,128,129$, $135,138,142,148-151,154,155,160,165-168,170$, $173,174,180,181,184,186,189,196,197,201$, $202,208,214,216-219,221,222,230,234,235$

Fungi $68,160,190$

Mycorrhizal fungi 22, 154, 155, 219

Insects $84,89,90,169,186,190$

Seed $35,73,75,76,78,99,101,105,107,108,152$, $165-167,180,181,184,190,209,216-218$

Home range 12, 164, 171

Habitat 5, 8, 12, 18, 19, 21, 23, 26, 30, 34, 38, 43-45, 55$58,61,62,72,86,87,90,94,103,104,106,109,113$, $117,128,129,135,136,139,141,142,144,145$, $148,150,153,159,161,162,164,175,177,179$, $183,192,194,198,204,211,221,222,224,225$, $227,228,232,233,236,237$

Life history 23

Migration 51, 77, 79, 122, 139, 206, 209, 215, 216, 218 Morphological adaption 91

Mortality $6,17,19,26,40,57,74,113,114,116,122$, $124,130,132,136,145,171,197,212,215,218$, 225, 226

Movements 12, 65, 161

Population density $3,7,8,10,14,15,17,19,21,24$, 32$34,36,37,41,44,46,51,53,56,59-61,63,67,70$, $73,74,77,79,83,85,88,93,94,98,100,101,106-$ $109,111,117-119,122,123,125,127,130,133$, $135,136,142,143,150,151,157,158,161,169$, $170,176,178,180,182,184,185,188,190,193$, $197,205,207,208,212,213,215,218,230$

Predation 9, 11, 15, 19, 21, 24, 32, 34, 41, 46, 47, 66, 93, $102,113,117,120,121,128,129,131-133,138$, $140,147,163,173,174,184,189,204,220,229$

Predators $3,5,10-12,21,23,27,31-34,41,46,51,52$, $54,59,62,64,70,80,86,93,98,104,112,117,120$, $121,123,128,133,134,135,138,144,148-150$, $153,156,161,162,164,168,171-176,183-185$, 187-189, 195, 197-201, 203, 204, 217, 220, 230

Reproduction 88,100,106,109, 122

Species composition $17,21,26,79,106,108,143,156$, 190, 192, 193

Species diversity $19,36,94,125,127,136,157$

\section{Plant Associations}

Brush grass 19, 44, 116, 119

Sagebrush-grass 71,228

Chaparral 40, 47, 136, 143, 197

Coastal marshes 82

Coniferous forest 27, 85, 117, 155, 170

Forest-field transition 72

Grassland 1, 15, 28, 29, 37, 44, 61, 62, 91, 131, 213

Larch-fir 88

Longleaf pine-wire grass-bracken fern 35

Mixed conifer-hardwood 135, 204

Oak-savanna 212
Pinyon-juniper 127, 201

Savanna 210

Spruce-fir 148, 204

Subalpine forest 94

Swamps 81

Transition zone forest 147

Upland woods 81

\section{Plant Species}

Alfalfa (Medicago spp.) 139

Aspen (Populus spp.) 86, 137, 151, 179, 182

Birch (Betula spp.) 179

Black spruce (Picea mariana) 152, 199, 224

Cheat grass (Bromus tectorum) 71

Corn (Zea mays) 115

Douglas-fir (Pseudotsuga menziesii) 25, 26, 74-79, 99, $101,106,109,110,165,166,171,180,209,214-$ 216,218

Idaho fescue (Fescue idahoensis) 217

Jack pine (Pinus banksiana) 7, 8, 152, 179, 202

Lodgepole pine (Pinus contorta) 50, 193, 227

Manzanita (Arctostaphylos spp.) 24

Mesquite (Prosopis spp.) 194

Oak (Quercus spp.) 63

Ponderosa pine (Pinus ponderosa) 3, 24, 45, 49, 107, $141,142,167,196,227$

Red fir (Abies magnifica) 217

Sagebrush (Artemisia spp.) 120, 156, 157

Sequoia (Sequoia spp.) 96, 97

Sitka spruce (Picea sitchensis) 95

Tamarack (Larix spp.) 84

Western hemlock (Tsuga heterophylla) 78, 95

Western juniper (Juniperus occidentalis) 153

Western redcedar (Thuja plicata) 80

White cedar (Thuja occidentalis) 87

White fir (Abies concolor) 216

White pine (Pinus monticola) 152

\section{Animal Species}

INSECTS 89, 90, 190 (also see specific species) Larch sawfly (Lygaeonematus erichsonii) 84

Spruce budworm (Choristoneura fumiferana) 170,186

FISH 4, 64, 110, 124, 223

AMPHIBIANS 62, 133, 223, 226

REPTILES 16, 34, 62, 102, 110, 116, 132, 198, 201, 223, 226

Bull snake (Pituophis sayi) 102, 198

BIRDS 4, 6, 7, 10, 16, 17, 21, 25, 28, 29, 35, 38, 47, 48, 50, $55,57,58,62,64,76,78,82,86,89,93,94,106,110$, $114,116,123,124,127,132,134,136,140-142$, $144,145,147,150,153,157,163,165,170,174$, $181,183,186,191,193,196,197,199,201,204$, 207, 213, 223, 225, 226, 237 (also see specific species)

Order Ansiformes (waterfowl)

Blue goose (Chen caerulescens) 82

Snow goose (Chen hyperborea) 82

Order Falconiformes (vultures, hawks, and falcons) 10 , $15,19,21,28,34,48,124,131,136,171$ (also see 
specific species)

California condor (Gymnogyps Californianus) 47, 57

Goshawk (Accipiter gentilis) 123

Red-tailed hawk (Buteo jamaicensis) 123

Order Galliformes (gallinaceous birds)

Domestic turkey (Meleagris spp.) 11

Ruffed grouse (Bonasa umbellus) 123

Bobwhite (Colinus virginianus) 207

Order Strigiformes (owls) 4, 9, 21, 24, 66, 123, 140,

147,163 (also see specific species)

Barn owl (Tyto alba) 9,66

Great horned owl (Bubo virginianus) 3, 66, 123

Spotted owl (Strix occidentalis) 147

Order Passeriformes (perching birds)

Loggerhead shrike (Lanius ludovidianus) 131

Pine siskin (Spinus pinus) 7

Oregon junco (Junco oreganus) 196

Nomenclature for birds according to:

U.S. Department of Agriculture

1978. Species list birds, mammals, fish, reptiles, and amphibians for the Forest Service. USDA For. Serv. R1 78-0r.2, $82 \mathrm{p}$.

\section{Mammals}

\section{Order Insectivora (insectivores)}

Family Soricidae (shrews) 4, 26, 78, 79, 84, 89, 95, 103, $112,158,165,166,180,190,215,233$ (also see specific species)

Masked shrew (Sorex cinereus) 36, 156, 192

Vagrant shrew (Sorex vagrans) 30, 43, 88, 156

Dusky shrew (Sorex obscurus) 192

Trowbridge's shrew (Sorex trowbridgii) 30, 218

Short-tailed shrew (Blarina brevicauda) 10

Family Talpidae (moles) 198 (also see specific species)

Shrew-mole (Neurotrichus gibbsii) 218

Order Lagomorpha (Lagomorphs)

Family Ochotonidae (pikas) 91, 173

Family Leporidae (hares and rabbits) 47, 80, 120, 124,

132 (also see specific species)

Cottontail rabbit (Sylvilagus spp.) 45, 141

Brush rabbit (Sylvilagus bachmani) 218

Nuttall's cottontail (Sylvilagus nuttallii) 159

Desert cottontail (Sy/vilagus audubonii) 121

Snowshoe hare (Lepus americanus) 3, 32, 33, 52,

$70,79,85,122,123,149,174,189,190,195$, $199,224,235$

Blacktail jackrabbit (Lepus californicus) 80, 121

Order Rodentia (rodents) 41, 101, 141, 142, 194 (also

see specific species)

Family Aplodontidae (mountain beaver)

Mountain beaver (Aplodontia rufa) 171

Family Sciuridae (squirrels)

Eastern chipmunk (Tamias striatus) 10, 72

Chipmunks (Eutamias spp.) 2, 4, 26, 74, 78, 103 , $128,141,186,214,215$

Least chipmunk (Eutamias minimus) $8,36,50$, 119, 156, 228

Yellow pine chipmunk (Eutamias amoenus) 34 , 94, 192, 196

Townsends chipmunk (Eutamias townsendii) 79 , $94,112,218$
Redtail chipmunk (Eutamias ruficaudus) 88

Unita ground squirrel (Spermophilus armatus) 156, 157

Columbian ground squirrel (Spermophilus Columbianus) 133, 146, 190

Thirteen-lined ground squirrel (Spermophilus tridecemlineatus) 1, 19

California ground squirrel (Spermophilus beecheyi) 79,218

Golden-mantled squirrel (Spermophilus /ateralis) $34,50,186,196,214,216$

Red squirrel (Tamiasciurus hudsonicus) 34, 72, 99, 149, 173, 186, 189, 190, 195, 199

Douglas' squirrel (Tamiasciurus douglasii) 79, 94, 96, 97, 218

Squirrels (Sciurus spp.) 211

Gray squirrel (Sciurus Carolinensis) 218

Fox squirrel (Sciurus niger) 72

Flying squirrels (Glaucomys spp.) 79, 160, 190, 218

Family Geomyidae (pocket gophers)

Pocket gophers (Thomomys spp.) 13, 26, 37, 49, $60,61,66,102,107,119,151,167,198,217$, $221,222,227$

Western pocket gopher (Thomomys mazama) 39

Family Heteromyidae (heteromyids)

Pocket mice (Perognathus spp.) 28, 121, 194

Great Basin pocket mouse (Perognathus parvus) 71,228

Kangaroo rats (Dipodomys spp.) 28, 121, 143, 194

Heermann's kangaroo rat (Dipodomys heermanni) 71

Family Castoridae (beavers)

Beaver (Castor canadensis) 59, 133, 137, 182, 195,199

Family Cricetidae (New World rats and mice) 52, 65, $78,89,198$ (also see specific species)

Harvest mice (Reithrodontomys spp.) 15, 24, 184

Eastern harvest mouse (Reithrodontomys humulis) 178

Western harvest mouse (Reithrodontomys megalotis) 1

Deer mouse (Peromyscus maniculatus) $1,7,8$, $19,24,26,28,30,36,50,63,71,74,75,77,79$, $80,88,92,94,95,100,103,105,106,112$, $115,118,119,128,133,135,139,143,153$, $156,157,167,169,177,179,180,186,189$, $190,192,196,202,208,209,212,213,228$, 234

Oldfield mouse (Peromyscus polionotus) 131, 178

White footed mouse (Peromyscus leucopus) 3 , $10,19,20,72,81,92,158,163,165,206,215$, 218,233

Cotton mouse (Peromyscus gossypinus) 130

Brush mouse (Peromyscus boylii) 143

Piñon mouse (Peromyscus truei) 24, 218

Golden mouse (Ochrotomys nuttalli) 130

Northern pigmy mouse (Baiomys taylori) 15

Northern grasshopper mouse (Onychomys leucogaster) 1 
Cotton rats (Sigmodon spp.) 15, 28, 130-132, 178, 207

Woodrats (Neotoma spp.) 121, 215

Bushy-tailed woodrat (Neotoma cinerea) 228

Dusky-footed woodrat (Neotoma fuscipes) 143, 218

Red-backed voles (Clethrionomys spp.) 8, 19, 36, $46,50,63,74,79,81,87,88,94,103,135,149$, $152,177,179,189,190,192,204,212,218$, 224, 231, 233

Heather vole (Phenacomys intermedius) 233

Voles (Microtus spp.) 9, 14, 26, 83, 84, 95, 118, $128,158,173,184,187,208,232$

Meadow vole (Microtus pennsylvanicus) 56, 63, 103, 135, 139, 156, 169, 204, 213, 233

Montane vole (Microtus Montanus) 71, 119, 156, 228

California vole (Microtus Californicus) 143

Tundra vole (Microtus oeconomus) 224

Rock vole (Microtus chrotorrhinus) 36

Creeping vole (Microtus oregoni) 30, 79, 109, 112

Prairie vole (Microtus ochrogaster) 1

Muskrat (Ondatra zibethicus) 82

Family Muridae (Old World rats and mice)

House mouse (Mus musculus) 115, 131, 178, 184

Family Zapodidae (jumping mice)

Western jumping mouse (Zapus princeps) 156, 233

Pacific jumping mouse (Zapus trinotatus) 30

Family Erethizontidae (New World porcupines)

Porcupine (Erethizon dorsatum) 52, 80, 190

Order Carnivora (carnivores)

Family Canidae (canids)

Coyote (Canis latrans) 11, 12, 59, 120, 123, 133, $134,171,172,174,217,220$

Arctic fox (Alopex lagopus) 93

Red fox (Volpes volpes) 131, 134, 185

Gray fox (Urocyon cinereoargenteus) 131, 134, 184

Family Procyonidae (procyonids)

Raccoon (Procyon lotor) 184, 210
Family Mustelidae (mustelids)

Marten (Martes americana) 31, 41, 46, 51, 52, 54, $59,98,117,128,129,133,138,144,148-150$, $161,164,168,173,185,187-189,195,199$, 200, 203, 204, 230, 236

Fisher (Martes pennanti) 51, 52, 54, 117, 144, 187,188

Weasel (Mustela spp.) 198

Ermine (Mustela erminea) 79, 144

Long-tailed weasel (Mustela frenata) 10, 156, 171

Mink (Mustela vison) 3

Wolverine (Gulo gulo) 59, 117, 176, 187

Badger (Taxidea taxus) 185

Skunk (Spilogale spp.) 112, 184

Family Felidae (cats)

Mountain lion (Felis concolor) 59, 133

Lynx (Felis Iynx) 32-34, 70, 123, 144

Bobcat (Felis rufus) 80, 121, 134

House cat (Felis domestica) 134

Order Artiodactyla (even-toed ungulates) 6, 21, 25, 27, $35,42,48,50,55,57,59,62,64,86,91,104,110,113$, $124,132,133,141,142,144,145,153,162,174$, 175, 183, 191, 193, 195, 197, 199, 201, 223, 237 (also see specific species)

Family Cervidae (cervids)

Elk (Cervus elaphus) 141

Mule deer (Odocoileus hemionus) 59, 220, 225

White-tailed deer (Odocoileus virginianus) 142

Moose (Alces alces) 59

Caribou (Rangifer tarandus) 59

Mammal nomenclature according to:

Jones, J. K., D. C. Carter, and H. H. Genoways

1975. Revised checklist of North American mammals north of Mexico. Texas Tech Univ. Mus. Occas. Pap. 28:1-14.

\section{General Reference Information}

Bibliography $13,21,27,50,68,145,181,183$

Identification key 104

Literature Review 191, 196 

Ream, Catherine $\mathrm{H}$.

1981. The effects of fire and other disturbances on small mammals and their predators: an annotated bibliography. USDA For. Serv. Gen. Tech. Rep. INT-106, 55 p. Intermt. For. and Range Exp. Stn., Ogden, Utah 84401.

An annotated bibliography (with keywords) on the effects of fire, logging, grazing, and spraying on small mammals and their predators. Includes a brief summary of the general effects of fire on some of the more common small mammals in western coniferous forests.

KEYWORDS: small mammals, predators, fire, logging, bibliography

Ream, Catherine $\mathrm{H}$.

1981. The effects of fire and other disturbances on small mammals and their predators: an annotated bibliography. USDA For. Serv. Gen. Tech. Rep. INT-106, 55 p. Intermt. For. and Range Exp. Stn., Ogden, Utah 84401.

An annotated bibliography (with keywords) on the effects of fire, logging, grazing, and spraying on small mammals and their predators. Includes a brief summary of the general effects of fire on some of the more common small mammals in western coniferous forests.

KEYWORDS: small mammals, predators, fire, logging, bibliography 
The Intermountain Station, headquartered in Ogden, Utah, is one of eight regional experiment stations charged with providing scientific knowledge to help resource managers meet human needs and protect forest and range ecosystems.

The Intermountain Station includes the States of Montana, Idaho, Utah, Nevada, and western Wyốminğ. About 231 million acres, or 85 percent, of thetarid area in the Station territory are classified as forest and rangetand. These lands include grasslands, deserts, shrublands, alpmareas, and well-stocked forests. They supply fiber for forest industries; minerals for energy and industrial development; and water for domestic and industrial consumption. They also provide recreation opportunities for millions of visitors each year.

Field programs and research work units of the Station are maintained in:

Boise, Idaho

Bozeman, Montana (in cooperation with Montana State University)

Logan, Utah (in cooperation with Utah State University)

Missoula, Montana (in cooperation with the University of Montana)

Moscow, Idaho (in cooperation with the University of Idaho)

Provo, Utah (in cooperation with Brigham Young University)

Reno, Nevada (in cooperation with the University of Nevada)

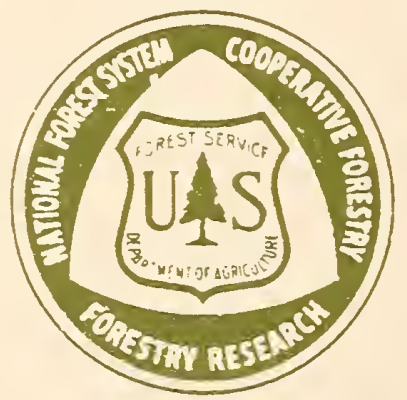

